\title{
Use of North Dakota Lignite In Advanced Power Systems
}

\section{Topical Report}

\section{W.G. Willson}

J.P. Hurley

L. Sharp

December 1992

Work Performed Under Contract No.: DE-FC21-86MC10637

For

U.S. Department of Energy

Office of Fossil Energy

Morgantown Energy Technology Center

Morgantown, West Virginia

By

Energy and Environmental Research Center

University of North Dakota

Grand Forks, North Dakota 


\title{
Use of North Dakota Lignite
} In Advanced Power Systems

\author{
Topical Report
}

\author{
W.G. Willson \\ J.P. Hurley \\ L. Sharp
}

Work Performed Under Contract No.: DE-FC21-86MC10637

\author{
For \\ U.S. Department of Energy \\ Office of Fossil Energy \\ Morgantown Energy Technology Center \\ P.O. B ox 880 \\ Morgantown, West Virginia 26507-0880
}

\author{
By \\ Energy and Environmental Research Center \\ University of North Dakota \\ Box 8213, University Station \\ Grand Forks, North Dakota 58202
}

December 1992 


\section{DISCLAIMER}

This report was prepared as an account of work sponsored by an agency of the United States Government. Neither the United States Government nor any agency thereof, nor any of their employees, makes any warranty, express or implied, or assumes any legal liability or responsibility for the accuracy, completeness, or usefulness of any information, apparatus, product, or process disclosed, or represents that its use would not infringe privately owned rights. Reference herein to any specific commercial product, process, or service by trade name, trademark, manufacturer, or otherwise does not necessarily constitute or imply its endorsement, recommendation, or favoring by the United States Govermment or any agency thereof. The views and opinions of authors expressed herein do not necessarily state or reflect those of the United States Government or any agency thereof.

This report has been reproduced directly from the best available copy.

Available to DOE and DOE contractors from the Office of Scientific and Technical Information, P.O. Box 62, Oak Ridge, TN 37831; prices available at (615) 576-8401.

Available to the public from the National Technical Information Service, U.S. Department of Commerce, 5285 Port Royal Rd., Springfield, VA 22161; phone orders accepted at (703) 487-4650. 


\section{DISCLAIMER}

Portions of this document may be illegible in electronic image products. Images are produced from the best available original document. 


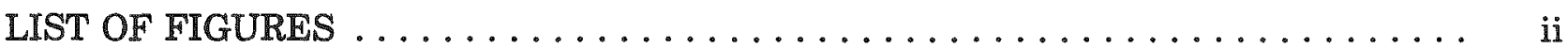

LIST OF TABLES $\ldots \ldots \ldots \ldots \ldots \ldots \ldots \ldots \ldots \ldots \ldots \ldots \ldots \ldots \ldots \ldots \ldots \ldots \ldots$ ii

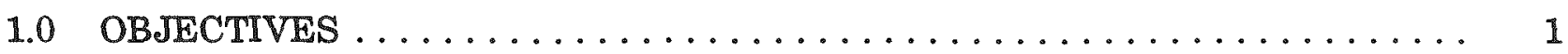

2.0 INTRODUCTION $\ldots \ldots \ldots \ldots \ldots \ldots \ldots \ldots \ldots \ldots \ldots \ldots \ldots \ldots \ldots \ldots \ldots$

3.0 EXPERIMENTAL $\ldots \ldots \ldots \ldots \ldots \ldots \ldots \ldots \ldots \ldots \ldots \ldots \ldots \ldots \ldots \ldots$

3.1 Gasification and Combustion Tests in the 4-lb/hr PFBR ......... 3

3.2 Coal Bed Analyses .............................. 3

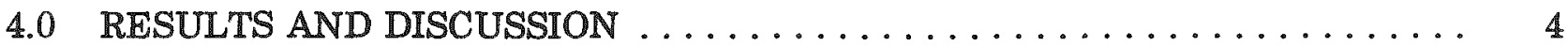

4.1 TGA Steam Reactivity Tests $\ldots \ldots \ldots \ldots \ldots \ldots \ldots \ldots \ldots \ldots \ldots$

4.2 Material Balances-PFBR . . . . . . . . . . . . . . . 4

4.3 Coal (Fixed-Carbon) Conversion $\ldots \ldots \ldots \ldots \ldots \ldots \ldots \ldots \ldots \ldots \ldots \ldots \ldots$

4.4 Sulfur Capture .............................. 5

4.5 Comparison of EERC Combustion Data with Those from Tidd . . . . . . . 6

4.6 Ammonia ............................. 6

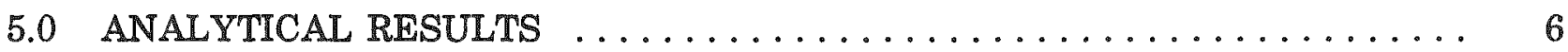

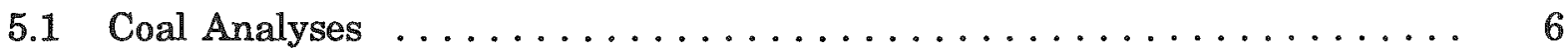

5.2 PFBR Bed Analyses . . . . . . . . . . . . . . . . . 7

5.3 Bed Material and Atmosphere Effects ............... 9

6.0 CONCLUSIONS AND RECOMIMENDATIONS $\ldots \ldots \ldots \ldots \ldots \ldots \ldots \ldots$

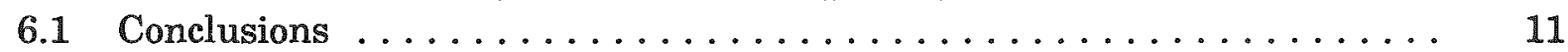

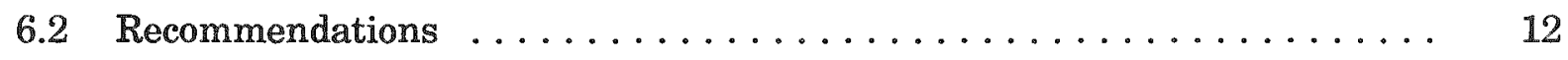

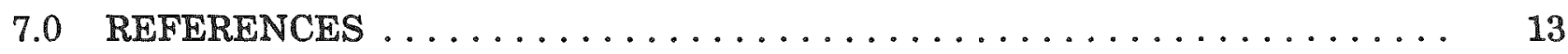

APPENDIX A: EXTENDED MATERIAL BALANCE SHEETS . . . . . . . . A A-1

APPENDIX B: SEMPC AND XRD DATA $\ldots \ldots \ldots \ldots \ldots \ldots \ldots \ldots \ldots \ldots \ldots$ 


\section{LIST OF FIGURES}

Figure

Page

$1 \quad 4-\mathrm{lb} / \mathrm{hr}$ pressurized fluid-bed reactor $(\mathrm{PFBR}) \ldots \ldots \ldots \ldots \ldots \ldots \ldots$

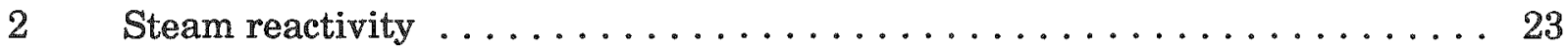

3 The major element compositions of agglomerates and bed materials from the high-sodium and blend tests at $800^{\circ}$ and $850^{\circ} \mathrm{C} \ldots \ldots \ldots \ldots 24$

4 The quantities of calcite (limestone), calcium oxide (calcined limestone), and calcium sulfate in the bed material from the high-sodium and blend

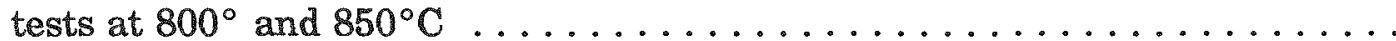

5 The input versus measured $\mathrm{Ca} / \mathrm{S}$ ratios in the agglomerates and bed materials from the high-sodium and blend tests at $800^{\circ}$ and $850^{\circ} \mathrm{C} \ldots \ldots 25$

6 SEM photograph of a cross section of a typical limestone particle remaining in the bed of the $850^{\circ} \mathrm{C}$ blended coal gasification test $\ldots \ldots \ldots \ldots \ldots \ldots$

7 Composition maps of calcium, sulfur, and sodium for the limestone particle

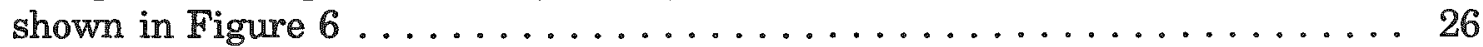

8 A portion of an agglomerate that formed during the $800^{\circ} \mathrm{C}$ high-sodium

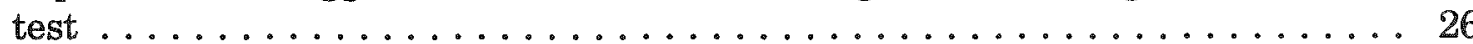

9 The major element compositions of the bed materials from the tests of different bed materials under gasification or combustion conditions . . . . . 27

10 The input versus measured $\mathrm{Ca} / \mathrm{S}$ ratios in the bed materials from tests of different bed materials under gasification or combustion conditions . . . . . 27

11 SEM photograph of a cross section of a typical limestone particle remaining

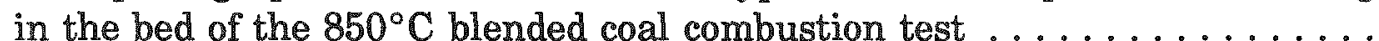

12 A close-up of the particle in Figure 11 showing its microporous nature

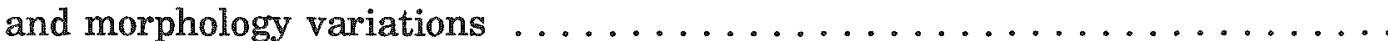

13 Composition maps of calcium, sulfur, sodium, and silicon for the particle

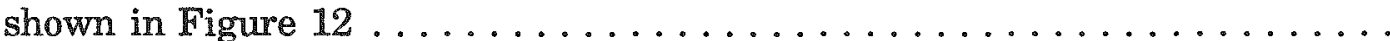

14 SEM photograph of a cross section of a typical dolomite particle remaining in the bed of the $850^{\circ} \mathrm{C}$ blended coal gasification test . . . . . . . . . . .

15 SEM photograph of a cross section of a portion of an agglomerate from the Cas addition test showing the relationship between the bright binder material and the residual bed particles that are cemented by it .......... 


\section{LIST OF TABLES}

\section{Table}

$1 \quad$ Analyses of Center Lignite $\ldots \ldots \ldots \ldots \ldots \ldots \ldots \ldots \ldots \ldots$

2 Feed Mixtures of Lignite from Two Seams and Bed Materials ......... 15

3 Partial Pressure of Feed and Product Gases ................ 16

4 Mass Balances Gasification and Combustion Tests . . . . . . . . . . 17

5 Conversion and Sulfur Capture - Gasification and Combustion Tests ...... 18

6 Comparison of EERC Bench-Scale Reactor to Tidd Operating Conditions . . . . 19

$7 \quad$ CCSEM Data for the Center Blend Coal . . . . . . . . . . . . . . . 20

8 Chemical Fractionation Data for the Center Blend Coal . . . . . . . . . 21 


\section{USE OF NORTH DAROTA LIGNITE IN ADVANCED POWER SYSTEMS}

\subsection{OBJECTIVES}

In order to develop critical data for Department of Energy (DOE) and private industry for advanced high-efficiency power systems using North Dakota lignite in pressurized gasification and combustion systems, tests were performed in bench-scale equipment at the Energy and Environmental Research Center (EERC). The primary objectives were to 1 ) determine the conversion levels for Center ND lignite under pressurized fluid-bed gasification conditions with sorbent addition as a function of temperature, 2) determine the sulfur capture using limestone or dolomite under gasification conditions giving $90 \%$ or higher carbon conversion, 3) evaluate char/coal conversion and sulfur capture in a pressurized fluid-bed combustor, and 4) assess the potential for bed agglomeration under the preferred operating conditions for both systems.

\subsection{INTRODUCTION}

Minnesota Power (MP) and its wholly owned subsidiary, BNI Coal, have been assessing advanced power systems in an effort to maintain a market for its Center lignite when the Clean Air Standard of $1.2 \mathrm{lb}$ of $\mathrm{SO}_{2} / \mathrm{MM}$ Btu comes into effect. At that time, none of the ND lignite currently being mined will be a compliance fuel. MP and BNI have decided that the Babcock and Wilcox (B\&W) advanced power concept which combines pressurized fluid-bed gasification (PFBG) and pressurized fluid-bed combustion (PFBC) with in-bed sulfur capture and hot-gas cleanup is very promising for boosting power system efficiency, while significantly reducing emissions.

The Center ND lignite is a highly reactive coal with relatively high levels of sodium and low ash fusion temperatures. While its high reactivity is beneficial, especially for gasification, its high alkali and low ash fusion temperature could alter sorbent-sulfur capture mechanisms and cause bed agglomeration problems. In an effort to address these issues, the EERC has entered into a jointly sponsored research project with $\mathrm{B} \& W$ to assess the performance of Center lignite under gasification and combustion conditions. The initial tests were performed under gasification conditions in a thermogravimetric analyzer (TGA) to determine the temperature range for $90+\%$ carbon conversion. Following TGA tests, eight gasification and two combustion tests were performed in the EERC nominal 4-lb/hr pressurized fluid-bed reactor (PFBR), shown in Figure 1. Detailed material balances provided carbon conversion and sulfur capture data, which have been supplemented by detailed analytical characterization of the bed materials.

The inorganic matter in low-rank coals (LRCs) is associated either as mineral particles or as ions present within the coal structure as salts of organic acids. Minerals such as quartz, clay, and pyrite make up essentially all of the inorganic material in highrank coals. In LRCs, they also make up the bulk of the discrete mineral matter, but as much as half of the inorganics are present as ions in direct organic associations, such as the salts of organic acids. These ions are primarily of alkali metal and alkaline earth elements, especially sodium and calcium. During combustion of the coal, they are vaporized for a short period and so become highly reactive. The vaporized alkaline earth elements calcium and magnesium rapidly oxidize and condense, often on the surface of the 
burning char particle. However, the alkali metals sodium and potassium are less refractory and tend to be stable in the gas phase at temperatures above $1050^{\circ} \mathrm{C}\left(1920^{\circ} \mathrm{F}\right)$, unless they come in contact with a solid material with which they can be chemically fixed. Below $1050^{\circ} \mathrm{C}$, sodium and potassium are more stable as condensed sulfates, although some may still be present in the vapor phase since the vapor pressures of the alkali species are relatively high. Much less is known about the reactions of vapor-phase alkali in gasification systems, especially since all rely on partial oxidation to supply process heat, so that individual ash particles pass through a complex mix of temperatures and atmospheres during their residence in the bed.

In fluidized-bed systems, the interaction of the vaporized elements, in particular sodium with the sulfur getter in the bed, can enhance the ability to capture sulfur. However, it can also cause the formation of materials that are molten at temperatures within normal operating conditions, or at least within the range of high-temperature excursions. These molten materials promote particle sintering and can cause complete agglomeration of the bed.

Although the average temperatures in a fluid-bed system may be below the temperature at which alkali sulfates precipitate, the surface temperatures of burning particles are higher, and poorly stirred regions in the bed may also reach higher temperatures. Above $1050^{\circ} \mathrm{C}$, the most likely candidates for reaction with vapor alkali are silicates, such as quartz, and aluminosilicates, such as clays. The reaction between quartz and sodium leads to the formation of material with a eutectic temperature of less than $800^{\circ} \mathrm{C}\left(1475^{\circ} \mathrm{F}\right)$ (Levin and others, 1964) and so it may be molten, leading to agglomeration of the bed material. Reactions with aluminosilicates are more favorable, since the melting points of sodium aluminosilicates are typically higher than those of the silicates. The melting point generally rises as the alumina content increases. These reactions can be exploited to capture or getter the alkali metals in the bed material and thus prevent them from causing corrosion problems farther downstream.

In areas of the bed that are well stirred, average temperatures are usually much below $1050^{\circ} \mathrm{C}$. At these temperatures in a combustion system (little is known about gasification systems), the alkali is most stable as a sulfate or carbonate. The reaction with sulfur can significantly increase the amount of sulfur fixed in the bed. However, the sodium can also form a sulfate solid solution with calcium that has a eutectic temperature of $900^{\circ} \mathrm{C}\left(1650^{\circ} \mathrm{F}\right)$ (Levin and others, 1964). This material may be molten within normal operating conditions and cause bed agglomeration. Also, if substantial magnesium is present, such as when dolomite is used as the bed material, a sodium/calcium/magnesium sulfate material can form with a eutectic temperature of $650^{\circ} \mathrm{C}\left(1200^{\circ} \mathrm{F}\right)$ (Levin and others, 1969). In addition, in pressurized gasification units where the partial pressure of carbon dioxide is high, low-temperature carbonate eutectic compositions can form. In pure sodium/calcium/carbonate systems, the eutectic temperature is $800^{\circ} \mathrm{C}\left(1475^{\circ} \mathrm{F}\right)$ (Levin and others, 1969).

In order to assess pressurized fluid-bed operation with a high-alkali lignite in terms of the potential for bed agglomeration and sulfur capture under both reducing and oxidizing conditions, eight gasification and two combustion tests were performed in the PFBR. Operational parameters that were tested included coal composition, bed temperatures, and bed materials. At the end of each test, bed and wall deposit samples were collected and analyzed by $\mathrm{x}$-ray diffraction (XRD) and advanced scanning electron 
microscopy (SEM) techniques to determine the sulfur capture efficiency of the bed and to determine the mechanisms by which any bed agglomeration occurred so that measures could be taken in subsequent tests to improve performance.

\subsection{EXPERIMENTAL}

\subsection{Gasification and Combustion Tests in the $4-1 b / h r$ PFBR}

Ten tests were performed in the PFBR: eight using steam to gasify different blends of Center lignite and two using air in a combustion mode. Two different samples of Center lignite representing the low- and high-sodium-containing seams $(0.8 \%$ and $8.3 \%$ ash sodium oxide contentrations) were used for this program (Table 1). Sorbent materials used included Pipe Rock limestone and Plum Run dolomite. The first three tests were run with the high-sodium sample, and the remaining tests were run with blend of equal parts of both samples, giving a feed sodium level of nominally $4.5 \%$, which is more representative of the actual coal blend that will be used at the Center plant. The two samples were then blended with sorbents or gettering agents to produce the feedstock illustrated in Table 2. Quantities of sorbent shown in Table 2 represented the expected makeup required to replace losses and maintain a constant bed. Run M265 was made with no added bed material, and Run M281 used dolomite. All other tests were made with a limestone bed. In the gasification tests all but the first shakedown run, M260, were performed at about 100 psi and at either $800^{\circ}$ or $850^{\circ} \mathrm{C}$. The steam/carbon ratio, including the inherent moisture in the lignite, was between 1 and 2 , giving the feed gas partial pressures shown in Table 3.

Standard operating procedure included a "prerun" period to establish steady-state conditions. The length of this prerun was typically the time required for a minimum of two bed changes. A material balance period, usually four hours in duration, followed. During this time, the material collected from the top bed drain and cyclones should have been representative of the bed material, if steady-state conditions were established. Any material accumulating in the condensation train was also collected every hour. Gas was metered by a dry gas meter, then sampled twice during the balance period using gas bags for gas chromatography (GC) analysis. An on-line IR spectrophotometer also monitored product gas composition. At the end of the material balance period, coal feed was terminated, heaters turned off, and the system cooled before the remaining bed material was collected. All feed gas mass flow rates, steam mass flow rates, and volumetric product gas rates were recorded every half hour, as were system pressures. Thermocouple temperature readings were recorded in a Lotus ${ }^{\circledast}$ spreadsheet every 30 seconds.

Standard analyses for material balance determination consisted of 16 component GC gas analyses and proximate and sulfur analyses on both char samples and the bed material, as shown in Table 4. Detailed analyses were then performed on the bed material samples to determine sulfur capture mechanisms, calcium utilization, and agglomeration tendencies.

\subsection{Coal Bed Analyses}

In order to determine the possible interactions that may occur between coal inorganics and bed materials, the form of the inorganics in the coal must be determined. 
The EERC has pioneered the use of several extractive and instrumental analysis techniques to allow the complete characterization of coal inorganics. Chemical fractionation was used to determine the concentration of organically associated elements in the coal by extracting a coal sample with a series of aqueous reagents. The technique involves extracting the coal with water to remove those elements associated with the groundwater, followed by ammonium acetate to remove organically associated alkali metal and alkaline earth elements, and finally with hydrochloric acid to remove elements associated in higher organic complexes or as carbonates.

The size and composition distributions of the minerals in the coal were obtained using computer-controlled scanning electron microscopy (CCSEM). It involves analyzing 2000 mineral grains and classifying them according to size and composition. The form and extent of the interactions between coal minerals and bed materials were determined with a combination of instrumental analyses of the pre- and posttest bed material. X-ray diffraction analysis was used to define the crystalline phases that form through the interactions. Scanning electron microscopy point count (SEMPC) was used to determine the composition distributions of the reacted bed materials. It involves the quantitative composition analysis of 250 points at the surface of a polished epoxy plug containing bed material. These analyses also indicated the degree of calcination of the bed materials and their efficiency at fixing sulfur. Also, manual SEM was used to determine the morphology of the sulfur reaction layers in representative bed samples.

\subsection{RESULTS AND DISCUSSION}

\subsection{TGA Steam Reactivity Tests}

The gasification reactivity of Center lignite was initially determined in steam with an atmospheric pressure TGA. Four tests were performed to determine conversion versus residence time as a function of temperature from $700^{\circ}$ to $900^{\circ} \mathrm{C}$. As illustrated in Figure 2, the Center lignite is typical of highly reactive $\mathrm{LRCs}$, giving virtually complete carbon gasification is less than 10 minutes at temperatures above $800^{\circ} \mathrm{C}$.

\subsection{Material Balances-PFBR}

Material balances for the gasification tests, shown in Table 4, were quite good, with the lowest being over $96 \%$ and the highest at $102 \%$. Material balance closure was made by balancing ash and nitrogen. Total material in and out were summed and the difference between the two noted. To normalize the mass balance, the difference was assigned to one or more of the four product streams (cyclone char, top bed drain char, liquids, and gas) based on ash and nitrogen balances. All raw and normalized material balance data are included in Appendix A.

An initial examination of the combustion tests (M280 and M283) and two of the gasification tests (M281, M282), based on the usual 4-hour material balance period, gave poor material balance data. After some reflection, it was determined that steady state in terms of a constant bed was not attained during the usual prerun and material balance periods. However, when the data were calculated based on the time coal feed started to the end of the run period, excellent material balances were attained. Therefore, composition of the bed material was considered in calculating conversion and sulfur 
capture. For example, in Run M280, $1012 \mathrm{~g}$ of ash was fed over the run period (7.33 hr @ $138 \mathrm{~g} / \mathrm{hr}$ ). Only $177 \mathrm{~g}$ was collected from the top bed drain, and the remainder, $843 \mathrm{~g}$, was found in the bed material. Taking into account material from the start to the end of coal feed, ash balance is about 101\%. For this reason, Runs M280 through M283 had longer material balance periods than the earlier runs.

\subsection{Coal (Fixed-Carbon) Conversion}

To calculate carbon conversion, fixed carbon in the feed is compared with fixed carbon in the char products:

$$
\% \text { conversion }=\frac{(F C \text { in }-F C \text { out })}{F C \text { in }} \times 100 \%
$$

Since the cyclone on this unit had not been optimized for this system, cyclone char was not considered to be a representative product. Therefore, the cyclone product, which represents only about $6 \%$ of the feed, was subtracted from the feed material and was not included in the product char for conversion calculations.

As shown in Table 5, the steam reactivity of Center lignite in a fluid bed of limestone was high, as shown in the earlier TGA tests. Over $90 \%$ fixed-carbon conversion was attained under steam gasification conditions for all temperatures $800^{\circ} \mathrm{C}$ and above and increased to between $97 \%$ to $99 \%$ at $850^{\circ} \mathrm{C}$. In the combustion mode at nominally $850^{\circ} \mathrm{C}$, carbon conversion was essentially complete.

\subsection{Sulfur Capture}

The sulfur content of the feed coal, coal/char, char bed material, and gas are also shown in Table 5 . Sulfur material balances were poor, mainly because the sulfur content of the gas and of the aqueous phase are elusive targets. Most of the sulfur not in the char or bed material comes through the system as $\mathrm{H}_{2} \mathrm{~S}$ and condenses in the water. $\mathrm{H}_{2} \mathrm{~S}$ that is not absorbed by the water in the condensate or reacted with vessel walls is in the product gas sampled by gas bags. Since $\mathrm{H}_{2} \mathrm{~S}$ condenses on the gas bag walls, GC analyses are not correct. Also, since $\mathrm{H}_{2} \mathrm{~S}$ is not stable in water, liquid sample analyses are not reliable either. For example, the initial $\mathrm{H}_{2} \mathrm{~S}$ concentration in the water sample of Run M262 was found to be $1500 \mathrm{mg} / \mathrm{L}$. Two subsequent tests for sulfur of this same sample showed sulfur content falling by approximately $20 \%$ each time, showing the instability of $\mathrm{H}_{2} \mathrm{~S}$ in water. In all cases, sulfur not found in the bed material or char was assumed to have gone into the gas phase as $\mathrm{H}_{2} \mathrm{~S}$.

In the first six runs, steady-state conditions were attained before the mass balance period, so the reported sulfur retention was based on the amount of sulfur that remained with the product char, regardless of whether it was truly captured by the ash/sorbent or whether it was actually still organic in unconverted char. Therefore, the reported sulfur retention numbers represent an upper limit for sulfur capture under the reported operating conditions. However, since, in all but the first test, conversions were above $90 \%$, it is a good approximation. In the last four tests where conversion and sulfur capture were based on the entire run, sulfur retention was based on both product char and bed sulfur levels. 
Sulfur capture in the gasification tests at $800^{\circ}$ to $850^{\circ} \mathrm{C}$ using limestone ranged from $12 \%$ to $36 \%$, with no apparent correlation to temperature. The test at $850^{\circ} \mathrm{C}$ with emathlite, which was mainly tested as a sodium gettering agent, showed better sulfur capture than limestone, at about $45 \%$. But by far the best sulfur capture under gasification conditions, around $67 \%$, was obtained with dolomite at $850^{\circ} \mathrm{C}$. For the two combustion tests at $850^{\circ} \mathrm{C}$, sulfur capture by limestone was around $50 \%$.

\subsection{Comparison of EERC Combustion Data with Those from Tidd}

Run M280 was made under operating conditions and $\mathrm{Ca} / \mathrm{S}$ ratios similar to those routinely used at the 73-MWe AEP Tidd PFBC (Table 6). The sulfur capture of about $48 \%$ in the EERC test was significantly below the $90 \%$ target value expected at Tidd (Clean Coal Technology Demonstration Program, 1992).

Probably the most significant difference between the EERC and Tidd tests was the sorbent utilized. Limestone was used in the EERC tests, and dolomite was used at Tidd. It has been demonstrated that sulfur capture under pressure is significantly higher for dolomite than limestone (Newby and Keairns, 1991). Another major difference was the nominal residence time, with that at Tidd's more than double that of the EERC's. Finally, the sulfur levels of the Ohio bituminous coal at around $4 \%$ were nearly an order of magnitude higher than the $0.7 \%$ sulfur in the North Dakota lignite. The much higher sulfur level for the Ohio coal provides a significant driving force for sulfur capture. Results from atmospheric fluidized-bed combustion (AFBC) testing have shown that higher $\mathrm{Ca} / \mathrm{S}$ ratios are required to obtain the same level of sulfur capture for low sulfur coals in comparison to high-sulfur coals (Mann and others, 1988, 1992).

\subsection{Ammonia}

In an effort to determine the amount of ammonia that might be produced under typical gasification conditions, a representative aqueous sample from Run M281 was collected and carefully preserved until it was analyzed. The ammonia concentration for Run M281 was measured at around $1140 \mathrm{mg} / \mathrm{L}$.

\subsection{ANALYTICAL RESULTS}

\subsection{Coal Analyses}

Tables 7 and 8 list the data from the CCSEM and chemical fractionation analyses of the Center blend coal used for the last seven PFBR tests. Only this coal was analyzed because demonstration- and commercial-scale tests will likely be run with a similar coal.

The CCSEM data show the composition distribution and size distribution of the mineral grains in the coal that have diameters between 1 and 100 microns. The majority of these mineral grains are either pyrite or quartz, with smaller amounts of mixed or unknown minerals (primarily mixtures of oxidized pyrite, quartz, clay, and gypsum), clays (kaolin or montmorillonite), and barite (barium sulfate). Although about $70 \%$ of the mineral grains are less than 10 microns in diameter, they are expected to undergo a great deal of coalescence with each other during combustion, so they will form large ash particles and tend to stay in the bed. 
The chemical fractionation data show that essentially all of the sodium and one-half to two-thirds of the calcium, magnesium, and potassium are extractable with water or ammonium acetate from the coal. These elements represent approximately one quarter of the mass of the coal ash. Most of the water-extractable elements are believed to be associated as ions in the moisture in the coal, while the ammonium acetate-extractable elements are present as ions held in organic complexes. It is believed that early in the combustion process the elements associated with the moisture in the coal can be expelled from the burning particles with the steam. In addition, the elements associated with organic structures are vaporized before the first $50 \%$ burnout of the combustible matter (Hurley and Schobert, 1992). These vaporized elements are very reactive and typically will interact with any condensed ash particles with which they come in contact. If they do not contact an ash particle, they will ultimately condense as temperatures drop and oxygen partial pressures increase as the gas moves away from the burning char particle. Much of the calcium and magnesium condense immediately as small globules on the char. These globules will usually coalesce with other ash or bed particles as the char burns out, although the calcium can also fix sulfur as calcium sulfate. Sodium and potassium vapors usually leave the burning char particle, but will react with minerals that they contact. They also can condense directly from the gas phase, often as very small particles that escape the bed and are difficult to collect.

In contrast to the alkali and alkaline earth elements, silicon, aluminum, and iron are insoluble in any of the extracting solutions. This indicates that they are present as insoluble minerals and so are not likely to vaporize and escape the bed. A comparison to the CCSEM data shows that the silicon is present either as quartz or aluminosilicate clays, the aluminum is present in clays, and the iron is present as pyrite. Much of the clay and some of the quartz is believed to be less than one micron in diameter, so they were not picked up by the CCSEM analysis. This would make the CCSEM data appear to show that pyrite represents a larger portion of the mineral matter than it actually does.

\subsection{PFBR Bed Analyses}

In addition to conversion data, the PFBR tests were designed to determine the effects of coal compositions, bed temperatures, atmospheres, and bed materials on bed agglomeration and sulfur capture. To simplify the discussion, it is divided into two parts: the first focusing on the effects of coal composition and bed temperature on operation, and the second discussing the effects of atmosphere and bed materials on operation. The summary sheets for the SEMPC and XRD analyses of all of the PFBR samples are presented in Appendix B.

The importance of coal composition on bed behavior during gasification was determined through tests of the high sodium (Seam 45) and blend (50\% Seam 45, 50\% Seam 17) fuels at both $800^{\circ} \mathrm{C}$ and $850^{\circ} \mathrm{C}$. Pipe Rock limestone was the bed material for these four tests.

No agglomeration was evident in the bed material from the $800^{\circ}$ and $850^{\circ} \mathrm{C}$ blend gasification tests. A small amount of bed agglomeration was evident in the $800^{\circ}$ and $850^{\circ} \mathrm{C}$ high- sodium tests. However, thin, lightly sintered wall deposits did form for each test at $800^{\circ} \mathrm{C}$ and above. The bed composition for each of the tests is shown in Figure 3. The figure summarizes the major element compositions (bulk compositions) of the bed materials. The greatest composition difference among the bed materials from the four 
tests is in the concentration of calcium. Since calcium is not expected to vaporize and the limestone should undergo similar levels of attrition for each test, the discrepancies between the two $800^{\circ} \mathrm{C}$ tests are most likely due to statistical variations in the samples or analyses. The SEMPC phase data indicate that little of the limestone was calcining. Figure 4 shows the quantities of calcite (limestone), calcium oxide (calcined limestone), and calcium sulfate in the bed material from each test. The calcite values include partially reacted materials that still contained significant amounts of carbonate. The figure shows that very little of the bed material reacted and the portion that did react was primarily converted to calcium sulfate. This is in contrast to the material found in the upper wall deposits. That material was completely calcined and partially sulfided so that only calcium oxide and calcium sulfide (not sulfate) were present.

Possibly because of the lack of calcination, none of the bed materials was efficient at fixing sulfur. Figure 5 compares the $\mathrm{Ca} / \mathrm{S}$ ratio of the feed material (bed + coal) versus the ratio measured in the bed at the end of the test. Assuming that the bed was at steady state so that the overflow material had a composition similar to the material remaining in the bed, then the sulfur capture efficiency was higher with the high-sodium coals. The higher capture efficiency has been noted in other EERC work in AFBC combustion tests of higher-sodium coals. However, overall efficiency of sulfur capture by the limestone was poor, as indicated by high calcium-to-sulfur ratios in the bed.

Figure 6 is an SEM photograph of a cross section of a typical limestone particle remaining in the bed of the $850^{\circ} \mathrm{C}$ blended coal test. It shows that the particles are somewhat fractured (possibly during preparation for analysis), but are not vesicular (porous) because they have not been calcined. Since they are not porous, they have relatively low surface area. The low surface area implies that gaseous sulfur species will have to diffuse through a thick reaction layer before they can be fixed by unreacted limestone; hence the reaction rate is low compared to calcined particles. The reaction layer is illustrated in the energy dispersive x-ray maps shown in Figure 7. The figure indicates the concentrations of calcium, sulfur, and sodium in the particle, shown in Figure 6, by the density of white dots in each of the quarters. The upper left quarter shows that calcium is concentrated throughout the particle, indicating that it is a limestone particle. The upper right quarter shows that the sulfur is fixed only at the rim of the particle and has not diffused to the interior. The lower left quarter shows that sodium played little role in this type of sulfur capture. However, sodium did play a significant role in the formation of agglomerates seen in the beds from both the $800^{\circ}$ and $850^{\circ} \mathrm{C}$ high-sodium tests. Figure 8 shows the type of particle where sodium was more prevalent. It shows a portion of an agglomerate that formed during the $800^{\circ} \mathrm{C} \mathrm{high-}$ sodium gasification test. The agglomerate is held together by a glassy matrix consisting of a calcium-sodium-sulfate-carbonate material with variable ratios on a point-by-point basis.

In addition to the bed agglomerates, deposits of much finer ash were present above the bed on reactor walls for each test run at $800^{\circ} \mathrm{C}$ or above. The deposits were agglomerated with a high sodium-calcium-sulfide matrix. All deposits formed in the freeboard under gasification conditions were agglomerated with sulfide material, whereas sulfate (or sulfite) and possibly carbonate dominated in the bed agglomerates. 


\subsection{Bed Material and Atmosphere Effects}

Five bed materials were tested under either gasification or combustion conditions to determine their effects on sulfur capture and bed agglomeration. The materials included limestone under gasification and combustion conditions; dolomite, limestone plus emathlite, and no getter material under gasification conditions; and limestone and limestone plus calcium sulfide under combustion conditions. A blend of coals from the two Center seams was used for all of the tests, as shown in Table 2. They were each run at a bed temperature of $850^{\circ} \mathrm{C}$.

No significant bed agglomeration was evident for any of the gasification tests, but 1to 2-inch-diameter agglomerates did form in each of the combustion tests. The major element compositions of the agglomerates for the combustion tests and the bulk bed materials for the gasification tests are illustrated in Figure 9. The main differences in compositions are the high calcium in the gasification limestone test, the low calcium and high magnesium in the dolomite test, and the low calcium and high iron and sulfur in the no sulfur getter addition test. The high calcium in the gasification limestone test is most likely due to a combination of reduced attrition, hence blowover of the limestone because it did not calcine, and sampling and analytical statistical variability. The lower calcium and higher magnesium in the dolomite test are caused by the composition of the dolomite which is approximately one-half calcite and one-half magnesite. The high iron in the nobed case is caused by differentiation in carryover due to variations in the aerodynamic diameters of the bed particles. The higher density of the iron-rich particles causes them to stay in the bed whereas lower density particles may be blown past the bed. Although this is also true in the tests where bed material is added, the effect is not as pronounced due to dilution by the bed. The $\left(\mathrm{CaO}+\mathrm{MgO}+\mathrm{Na}_{2} \mathrm{O}\right) / \mathrm{SO}_{3}$ ratio in the bed indicates that the alkalies are fully sulfated in the no-bed test.

Figure 10 shows the calcium-to-sulfur ratios in the combustion agglomerates and the gasification bed materials as compared to the feed materials for the different bed tests. The Ca/S ratios in the feed materials were approximately 2 or less, whereas in the actual bed material the ratios were much higher. If what remained in the bed was indicative of what was elutriated, then the high $\mathrm{Ca} / \mathrm{S}$ ratios indicate poor sulfur capture efficiency for all of the tests. However, not all of the beds may have been at steady state. Also, the elutriated materials may have been more highly sulfated.

The relatively poor sulfur capture of the limestone in the PFBR tests is in contrast to the efficiency of limestone in capturing sulfur in the pilot-scale B\&W tests. The reduced capture efficiency is believed to be due to reduced surface area (as observed by SEM) of sulfur getter material in the PFBR tests as compared to the B\&W combustion tests. The reduced surface area in the PFBR tests is due to the higher $\mathrm{CO}_{2}$ partial pressures in those tests. The higher pressures slow the calcination of the limestone in the combustion tests which may cause larger pores with less surface area to form than in an atmospheric test. In the gasification tests, calcination was effectively prevented, thereby preventing the formation of pores which would increase the surface area for reaction. Since reaction could only occur at the outer surface, the reaction rate was limited by the diffusion of species through a relatively thick reaction layer, rather than by diffusion of gas through pores. 
SEM analyses of the bed materials showed several effects of the use of different bed materials and atmospheres on the morphologies and composition distributions of the bed materials. The morphologies of the bed materials indicate that under combustion conditions more calcination of the bed occurred than under gasification conditions. Figure 11 shows a representative limestone bed particle from the test of Center coal blend at $850^{\circ} \mathrm{C}$ under combustion conditions. In contrast to a gasification particle, shown in Figure 6, the combustion particle is much more porous, probably because of partial calcination. These pores allow sulfurous gases to penetrate into the particle and become fixed more effectively than if no pores were present. Figure 12 is a close-up of the lower right portion of the particle that better illustrates the porosity. A composition map of the area is shown in Figure 13. The upper left map quadrant shows the calcium distribution in the close-up photograph. Calcium is found throughout the particle, but is primarily concentrated on the left side which is directly derived from the original limestone particles. The lower right quadrant of Figure 13 shows the silicon content, indicating that the lower right of the particle is composed of silicate material that fused to the limestone grain. The distribution of sulfur in the silicate and limestone particles is shown in the upper right quadrant. It indicates that sulfur fixation occurs within the pore structure of both the limestone- and silicate-derived materials. This is in contrast to the outer coatings of sulfate that occurred in the gasification tests. Sulfur is fixed in the limestone from the combustion tests primarily in the pores as calcium sulfate, but some fixation also occurs in the silicate material. The lower left quadrant shows the sodium concentrations in the particles. It reveals that the sulfur associated with the silicate is fixed as sodium sulfate on the walls of the vesicles in the silicate material. In general, the distributions of elements in the combustion test beds was much more varied than in the gasification tests, showing much more interaction between the bed and the ash, forming considerably more complex distributions of condensed phases.

The increased interaction in the combustion tests is the probable cause of the greater bed agglomeration in those tests. Interaction was higher than in gasification tests because, in combustion, the individual coal particles reach higher temperatures and possibly because the limestone partially calcined in combustion, forming lime which is believed to be more reactive to the silicates. The lime fluxed the silicates, forming lower melting point compounds than if the limestone had not calcined. Also, when calcium sulfide was added, it did not completely oxidize, and the sulfur played a partial role in the formation of the agglomerates.

Like the limestone in the combustion tests, Figure 14 shows that the dolomite from the gasification test was porous. However, the presence of euhedral crystals indicates that the pores are naturally occurring and do not form because of calcination. This means that dolomite will have a larger surface area than the limestone under conditions where calcination does not occur. This advantage will be reduced or lost in combustion systems, especially at atmospheric pressure because of the calcination of the limestone. In addition, it is not clear if sulfur fixation by the magnesium is as efficient as the calcium under gasification systems (it is known that magnesium is more stable as an oxide than a sulfate under combustion conditions). If magnesium does not fix the sulfur, then dolomite is inherently less efficient at fixing sulfur than limestone with a similar surface area.

In addition to tests of sulfur-gettering ability, an attempt was also made to getter sodium and thus prevent agglomeration of the bed by sodium-rich materials. Emathlite is a naturally occurring fuller's earth that forms through chemical alteration of volcanic 
ash. It has been shown to be an effective sodium getter in pulverized coal combustion (McLaughlin, 1990). In the PFBR, no agglomeration was evident in the bed to which it was added, although neither was agglomeration evident in the bed formed under similar conditions without the emathlite. Therefore, its effectiveness at preventing agglomeration could not be ascertained in this test. However, the emathlite is composed primarily of quartz and cristobalite (a metastable high-temperature silica that is a slight respiration hazard), with a small amount of aluminosilicate clay. If it had absorbed much sodium from the gas stream, a sodium silicate material with a low melting point might form that could agglomerate the bed. Therefore, we recommend the testing of kaolin rather than emathlite to reduce agglomeration during combustion. Kaolin commonly occurs in North Dakota lignites and may be present in high concentrations in the overburden at the Center mine.

The final PFBR test involved the addition of calcium sulfide under combustion conditions to determine the extent of sulfide oxidation. Bed agglomeration did occur in this test, as it had in the other combustion test. XRD analyses showed that most of the limestone had calcined and no crystalline sulfide materials were remaining. However, SEM analyses of the agglomerates indicate that some sulfide remained in the bed, although it was usually present in a complex amorphous calcium-silicon-iron sulfide form. It was this material that appears to be forming the matrix that binds the agglomerates. Figure 15 shows a portion of an agglomerate showing the relationship between this bright binder material and the residual bed particles that are cemented by it. Laboratory-scale atmospheric pressure FBC simulations performed elsewhere have also shown incomplete CaS oxidation and also $\mathrm{CaSO}_{4}$ decomposition yielding $\mathrm{SO}_{2}$ gas (Pham \& Lawson, 1990). Proper bed conditions were deemed essential to proper CaS oxidation without subsequent decomposition, although the conditions had not yet been determined.

\subsection{CONCLUSIONS AND RECOMMENDATIONS}

\subsection{Conclusions}

- Center lignite gasifies readily with over $90 \%$ conversion at temperatures of $800^{\circ} \mathrm{C}$ and above.

- There were no signs of significant limestone or dolomite bed agglomeration under gasification conditions up to $850^{\circ} \mathrm{C}$ using of the blended coal with around $4.5 \%$ $\mathrm{Na}$ in the ash.

- Under gasification conditions at temperatures up to $850^{\circ} \mathrm{C}$, little limestone or dolomite calcination occurred.

- The porosity and surface area was significantly higher for the dolomite, than for the limestone used in these tests.

- In situ sulfur capture by limestone under gasification conditions was much lower than for dolomite. 
- Sulfur capture by limestone under combustion conditions was somewhat higher than for gasification; however, it did not approach the sulfur capture seen at Tidd using dolomite.

- Significant bed agglomeration did occur in PFBC tests with limestone at $850^{\circ} \mathrm{C}$.

- In the PFBC test where CaS was added to simulate operation expected in the demonstration project, not all of the sulfide was oxidized; some remained as complex mineral sulfides.

- Contrary to expectation, the complexity of the bed-Center lignite mineral matter interactions and the range of mineral complexes produced were far greater for combustion than for gasification, primarily because of greater bed calcination under combustion conditions.

\subsection{Recommendations}

- Due to agglomeration tendencies of limestone and Center lignite mineral matter during $\mathrm{PFBC}$ tests at $850^{\circ} \mathrm{C}$, much more work will be required on $\mathrm{PFBC}$ during the design phase.

- Additional work on the use of sodium getters during combustion is called for.

- Due to the poor performance of limestone for in situ sulfur capture under both PFBC and PFBG conditions, additional work with other sorbents, especially dolomite, is warranted.

- To properly relate commercial PFBC operating experience and sulfur capture efficiency, operating parameters, including possibly some hardware modification, should be implemented at the EERC to increase residence times and bed heights to better simulate Tidd operation.

- To increase the sulfur capture efficiencies of limestone, methods should be assessed for increasing its surface area, including:

- Increasing the bed temperature to force calcination under pressurized gasification conditions, which may need to be done in conjunction with the addition of a sodium getter such as kaolin to prevent bed agglomeration.

- Searching for a limestone that calcines better under the pressure and stoichiometries of preference.

- Seeking a limestone that has a higher naturally occurring surface area, much as does dolomite.

- Investigating diverting a slipstream of bed material from the PFBC which contains partially calcined limestone as bed makeup. 
- An assessment should be made regarding whether the sulfides remaining after combustion are an artifact of the spiking experiment or can be expected from sulfided bed material from the PFBG.

- If unoxidized sulfides are shown to be a real possibility, additional testing will be required to assess leachability and/or how to obtain complete oxidation.

\subsection{REFERENCES}

Clean Coal Technology Demonstration Program: Program Update 1991; U.S. Department of Energy, Washington, DC, DOE/FE-0247P, Feb. 1992.

Hurley, J.P.; Schobert, H.H. "Ash Formation During Pulverized Subbituminous Coal Combustion: 1. Characterization of Coals and Inorganic Transformations During Early Stages of Burnout," Energy and Fuels 1992, 4, 45-58.

Levin, E.M.; Robbins, C.R.; MeMurdie, H.F. Phase Diagrams for Ceramists; The American Ceramic Society: Columbus, $\mathrm{OH}, 1964$.

Levin, E.M.; Robbins, C.R.; McMurdie, H.F. Phase Diagrams for Ceramists - 1969 Supplement, The American Ceramic Society: Columbus, OH, 1969.

Mann, M.D.; Hajicek, D.R.; Henderson, A.K.; Moe, T.A. "Comparison of CFBC Performance as a Function of Coal Rank," Presented at the International Power Generation Conference, Atlanta, GA, Oct. 18-22, 1992.

Mann, M.D.; Zobeck, B.J.; Hajicek, D.R. "Comparison of FBC Performance as a Function of Coal Rank," Presented at the Joint ASME/IEEE Power Generation Conference, Philadelphia, PA, Sept. 25-29, 1988.

McLaughlin, J. The Removal of Volatile Alkali Salt Vapours from Hot Coal-Derived Gases, Ph.D. Thesis, University of Surrey, Surrey, England, 1990.

Newby, R.A.; Keairns, D.L. "FBC Sulfur Removal--Do We Know Enough?" In Proceedings of the 1991 International Conference on Fluidized Bed Combustion; Anthony, E.J, Ed.; The American Society of Mechanical Engineers, Montreal, Canada, Apr. 21-24, 1991.

Pham, N.H.; Lawson, W.F. "An Oxidation Study of Fluidized-Bed Ashes Containing Calcium Sulfide," Presented at the AIChE Annual Meeting, Clean Coal Technology II Session, Chicago, IL, 1990. 
TABLE 1

Analyses of Center Lignite

\begin{tabular}{lcc}
\hline As-Received & Seam $\# 45$ & Seam \#17 \\
\hline Proximate Analysis & & \\
Moisture & 37.5 & 38.4 \\
Volatile Matter & 27.7 & 27.4 \\
Fixed Carbon & 29.9 & 29.3 \\
Ash & 4.9 & 4.8 \\
Ultimate Analysis & & \\
Hydrogen & 6.7 & 7.1 \\
Carbon & 41.2 & 40.5 \\
Nitrogen & 0.6 & 0.6 \\
Sulfur & 0.9 & 0.7 \\
$\mathrm{Oxygen}_{\mathrm{Ash}}$ & 45.6 & 46.3 \\
$\mathrm{EDXRF}_{\mathrm{SiO}}$ & 4.9 & 4.8 \\
$\mathrm{Al}_{2} \mathrm{O}_{3}$ & & \\
$\mathrm{Fe}_{2} \mathrm{O}_{3}$ & 15.2 & 22.7 \\
$\mathrm{TiO}_{2}$ & 7.4 & 9.6 \\
$\mathrm{P}_{2} \mathrm{O}_{5}$ & 10.2 & 8.1 \\
$\mathrm{CaO}_{\mathrm{MgO}}$ & 0.4 & 0.5 \\
$\mathrm{Na}_{2} \mathrm{O}$ & 0.6 & 0.2 \\
$\mathrm{~K}_{2} \mathrm{O}$ & 25.5 & 27.6 \\
$\mathrm{SO}_{3}$ & 9.1 & 10.9 \\
& 8.3 & 0.8 \\
& 0.3 & 0.3 \\
& 23.1 & 19.3 \\
\hline
\end{tabular}


TABLE 2

Feed Mixtures of Lignite from Two Seams and Bed Materials

\begin{tabular}{lrrrrrrrrrr}
\hline & M260 & M261 & M262 & M263 & M264 & M265 & M280 & M281 & M282 & M283 \\
\hline Temperature, ${ }^{\circ} \mathrm{C}$ & 700 & 800 & 850 & 800 & 850 & 850 & 850 & 850 & 850 & 850 \\
Solids Feed Mix, g/hr & 1,816 & 1,816 & 1,816 & 1,816 & 1,816 & 1,816 & 1,816 & 1,816 & 1,816 & 1,816 \\
Coal Seam \#45 & 1,737 & 1,737 & 1,737 & 877 & 877 & 908 & 877 & 885 & 856 & 856 \\
Coal Seam \#17 & & & & 877 & 877 & 908 & 877 & 885 & 856 & 856 \\
$\quad$ Makeup Limestone & 79 & 79 & 79 & 62 & 62 & & 62 & & 61 & 61 \\
Makeup Dolomite & & & & & & & & 46 & & \\
Emathlite & & & & & & & & & 42 & \\
Ca/S & & & & & & & & & & 39 \\
Overall Ca/S & 2.4 & 2.4 & 2.4 & 2.2 & 2.2 & 1.2 & 2.2 & 2.0 & 2.2 & 1.3 \\
& & & & & & & & & & \\
Other Feed Materials & & & & & & & & & & \\
Water, g/hr & 1,529 & 2,232 & 1,804 & 2,490 & 1,106 & 3,070 & 653 & 2,069 & 1,112 & 653 \\
$\mathrm{~N}_{2}$, g/hr & 8,866 & 15,990 & 15,456 & 14,803 & 13,962 & 12,486 & 15,934 & 13,484 & 12,624 & 15,681 \\
$\mathrm{O}_{2}$, g/hr & 7 & 544 & 479 & 477 & 487 & 436 & 2,591 & 487 & 484 & 2,641 \\
\hline
\end{tabular}


TABLE 3

Partial Pressure of Feed and Product Gases

\begin{tabular}{lcccccccccc}
\hline & M260 & M261 & M262 & M263 & M264 & M265 & M280 & M281 & M282 & M283 \\
\hline Gas In & & & & & & & & & & \\
Steam & 10.6 & 17.4 & 15.0 & 20.3 & 21.0 & 27.1 & 5.3 & 18.8 & 19.2 & 5.3 \\
$\mathrm{~N}_{2}$ & 39.4 & 80.2 & 82.8 & 77.5 & 76.7 & 70.8 & 82.9 & 78.7 & 78.2 & 82.5 \\
$\mathrm{O}_{2}$ & 0.1 & 2.4 & 2.2 & 2.2 & 2.3 & 2.2 & 11.8 & 2.5 & 2.6 & 12.2 \\
Gas Out & & & & & & & & & & \\
$\mathrm{H}_{2}$ & 3.9 & 8.0 & 7.7 & 7.1 & 6.5 & 10.0 & 0.0 & 8.3 & 9.0 & 0.0 \\
OO $_{2}$ & 1.7 & 4.9 & 4.7 & 5.1 & 4.3 & 6.3 & 9.5 & 5.5 & 5.2 & 11.3 \\
Propylene & 0.03 & 0.00 & 0.00 & 0.02 & 0.0 & 0.00 & 0.03 & 0.03 & 0.01 & 0.0 \\
$\mathrm{H}_{2}$ S & 0.04 & 0.02 & 0.00 & 0.04 & 0.0 & 0.04 & 0.00 & 0.02 & 0.04 & 0.0 \\
Ethylene & 0.05 & 0.07 & 0.12 & 0.04 & 0.0 & 0.05 & 0.01 & 0.05 & 0.05 & 0.0 \\
Ethane & 0.04 & 0.00 & 0.00 & 0.03 & 0.0 & 0.00 & 0.00 & 0.05 & 0.01 & 0.0 \\
Nitrogen & 86.7 & 83.9 & 83.8 & 84.8 & 86.3 & 79.2 & 88.4 & 82.0 & 81.3 & 87.7 \\
Methane & 1.1 & 1.0 & 1.0 & 1.0 & 0.4 & 1.2 & 0.0 & 0.9 & 1.0 & 0.0 \\
CO & 0.9 & 2.2 & 2.7 & 1.9 & 2.5 & 3.3 & 0.0 & 3.2 & 3.3 & 0.0 \\
O & & & & & & & 2.0 & & & 2.0 \\
\hline
\end{tabular}


TABLE 4

Mass Balances Gasification and Combustion Tests

\begin{tabular}{|c|c|c|c|c|c|c|c|c|c|c|}
\hline $\operatorname{Run}$ & $\mathrm{M} 260 \mathrm{~g} \mathrm{In}$ & g Out & M261 g In & g Out & M262 $\mathrm{g}$ In & g Out & M263 g In & gout & M264 g In & g Out \\
\hline $\begin{array}{l}\text { Coal/Char-maf } \\
\mathrm{H}_{2} \mathrm{O} \text {-Coal/Char } \\
\text { Steam Feed }\left(\mathrm{H}_{2} \mathrm{O}\right) \\
\text { Ash } \\
\text { Sulfur }\end{array}$ & $\begin{array}{r}4,216 \\
2,612 \\
3,505 \\
427 \\
46\end{array}$ & $\begin{array}{r}2,287 \\
29 \\
5,187 \\
426 \\
40\end{array}$ & $\begin{array}{r}4,216 \\
2,612 \\
6,316 \\
427 \\
45\end{array}$ & $\begin{array}{r}412 \\
23 \\
5,921 \\
429 \\
30\end{array}$ & $\begin{array}{r}4,216 \\
2,612 \\
4,605 \\
427 \\
46\end{array}$ & $\begin{array}{r}395 \\
23 \\
4,644 \\
429 \\
24\end{array}$ & $\begin{array}{r}4,223 \\
2,612 \\
7,349 \\
421 \\
46\end{array}$ & $\begin{array}{r}328 \\
22 \\
6,139 \\
401 \\
41\end{array}$ & $\begin{array}{r}4,223 \\
2,612 \\
7,215 \\
421 \\
46\end{array}$ & $\begin{array}{r}117 \\
9 \\
6,923 \\
353 \\
12\end{array}$ \\
\hline $\begin{array}{l}\text { Gas Total } \\
\mathrm{H}_{2} \\
\mathrm{CO}_{2} \\
\mathrm{C}_{3} \mathrm{H}_{\mathrm{x}} \\
\mathrm{H}_{2} \mathrm{~S} \\
\mathrm{C}_{2} \mathrm{H}_{4} \\
\mathrm{C}_{2} \mathrm{H}_{6} \\
\mathrm{O}_{2} \\
\mathrm{~N}_{2} \\
\mathrm{CH}_{4} \\
\mathrm{CO} \\
\mathrm{NH}_{3}\end{array}$ & $\begin{array}{r}30 \\
35,464\end{array}$ & $\begin{array}{r}39,393 \\
230 \\
2,202 \\
19 \\
20 \\
21 \\
18 \\
0 \\
36,253 \\
268 \\
362 \\
0\end{array}$ & $\begin{array}{r}2,175 \\
63,968\end{array}$ & $\begin{array}{r}71,899 \\
427 \\
5,717 \\
0 \\
18 \\
52 \\
0 \\
0 \\
63,657 \\
411 \\
1,617 \\
0\end{array}$ & $\begin{array}{r}1,914 \\
61,825\end{array}$ & $\begin{array}{r}69,483 \\
397 \\
5,320 \\
0 \\
0 \\
87 \\
0 \\
0 \\
61,331 \\
417 \\
1,931 \\
0\end{array}$ & $\begin{array}{r}1,910 \\
59,210\end{array}$ & $\begin{array}{r}66,486 \\
345 \\
5,472 \\
21 \\
33 \\
27 \\
22 \\
0 \\
58,877 \\
400 \\
1,289 \\
0\end{array}$ & $\begin{array}{r}1,948 \\
55,847\end{array}$ & $\begin{array}{r}62,099 \\
295 \\
4,327 \\
0 \\
0 \\
0 \\
0 \\
0 \\
56,751 \\
146 \\
1,581 \\
0\end{array}$ \\
\hline $\begin{array}{l}\text { Total } \\
\text { Mass Balance\% }\end{array}$ & 46,255 & $\begin{array}{r}47,323 \\
102 \%\end{array}$ & 79,705 & $\begin{array}{r}78,685 \\
99 \%\end{array}$ & 75,600 & $\begin{array}{r}74,973 \\
99 \%\end{array}$ & 75,725 & $\begin{array}{r}73,376 \\
97 \%\end{array}$ & 72,266 & $\begin{array}{r}69,501 \\
96 \%\end{array}$ \\
\hline Run & M265 g In & g Out & $\mathrm{M} 280 \mathrm{~g}$ In & $\mathrm{g}$ Out & $\mathrm{M} 281 \mathrm{~g}$ In & g Out & M282 g In & g Out & M283 g In & g Out \\
\hline 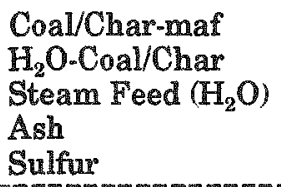 & $\begin{array}{r}4,334 \\
2,612 \\
9,666 \\
310 \\
46\end{array}$ & $\begin{array}{r}146 \\
8 \\
8,706 \\
305 \\
34\end{array}$ & $\begin{array}{r}7,502 \\
4,789 \\
0 \\
1,011 \\
78\end{array}$ & $\begin{array}{r}180 \\
7 \\
6,782 \\
1,020 \\
38\end{array}$ & $\begin{array}{r}5,944 \\
3,918 \\
8,495 \\
1,022 \\
64\end{array}$ & $\begin{array}{r}177 \\
12 \\
7,759 \\
705 \\
46\end{array}$ & $\begin{array}{r}5,499 \\
3,788 \\
7,756 \\
1,234 \\
72\end{array}$ & $\begin{array}{r}515 \\
20 \\
9,703 \\
864 \\
73\end{array}$ & $\begin{array}{r}5,811 \\
3,788 \\
0 \\
923 \\
118\end{array}$ & $\begin{array}{r}50 \\
4 \\
6,141 \\
849 \\
61\end{array}$ \\
\hline $\begin{array}{l}\text { Gas Total } \\
\mathrm{H}_{2} \\
\mathrm{CO}_{2} \\
\mathrm{C}_{3} \mathrm{H}_{2} \\
\mathrm{H}_{2} \mathrm{~S} \\
\mathrm{C}_{2} \mathrm{H}_{4} \\
\mathrm{C}_{2} \mathrm{H}_{6} \\
\mathrm{O}_{2} \\
\mathrm{~N}_{2} \\
\mathrm{CH}_{4} \\
\mathrm{CO} \\
\mathrm{NH}_{3}\end{array}$ & $\begin{array}{r}1,743 \\
49,945\end{array}$ & $\begin{array}{r}58,895 \\
444 \\
6,101 \\
0 \\
30 \\
31 \\
0 \\
0 \\
49,824 \\
425 \\
2,040 \\
0\end{array}$ & $\begin{array}{r}19,002 \\
116,847\end{array}$ & $\begin{array}{r}139,434 \\
1 \\
19,692 \\
59 \\
0 \\
13 \\
0 \\
3,045 \\
116,622 \\
0 \\
0 \\
0\end{array}$ & $\begin{array}{r}2,925 \\
80,905\end{array}$ & $\begin{array}{r}93,713 \\
588 \\
8,556 \\
44 \\
24 \\
49 \\
0 \\
0 \\
80,798 \\
496 \\
3,157 \\
0\end{array}$ & $\begin{array}{r}2,810 \\
73,218\end{array}$ & $\begin{array}{r}84,817 \\
581 \\
7,363 \\
14 \\
44 \\
45 \\
10 \\
0 \\
73,247 \\
505 \\
3,010 \\
0\end{array}$ & $\begin{array}{l}15,319 \\
90,947\end{array}$ & $\begin{array}{r}111,939 \\
0 \\
18,447 \\
31 \\
0 \\
0 \\
0 \\
2,396 \\
91,015 \\
0 \\
0 \\
0\end{array}$ \\
\hline Total & 68,610 & 68,061 & 149,150 & 147,423 & 103,208 & 102,365 & 94,304 & 95,917 & 116,788 & 118,984 \\
\hline Mass Balance\% & & $99 \%$ & & $99 \%$ & & $99 \%$ & & $102 \%$ & & $102 \%$ \\
\hline
\end{tabular}


TABLE 5

Conversion and Sulfur Capture - Gasification and Combustion Tests

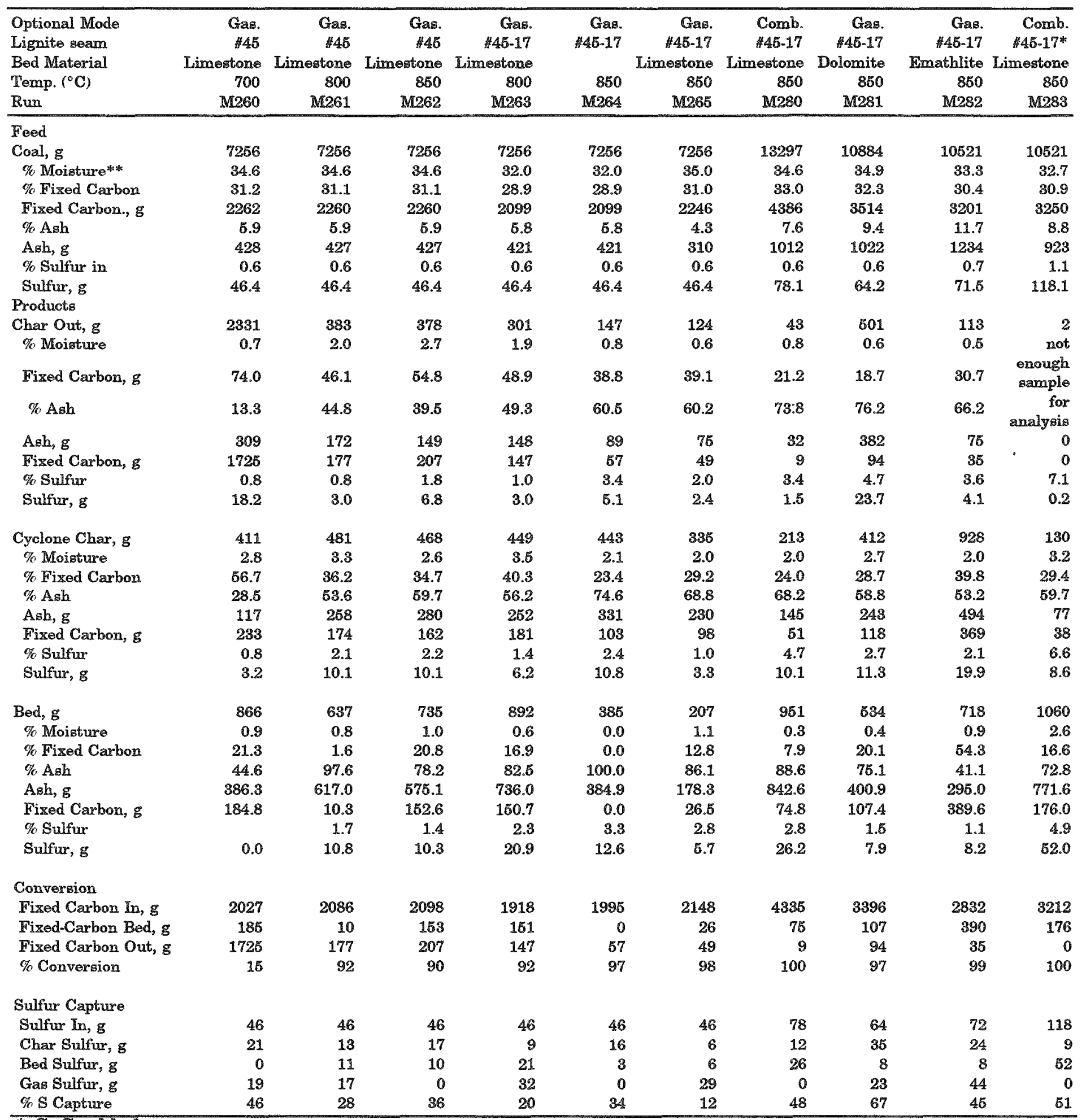

* Cas added.

** as-received. 
TABLE 6

Comparison of EERC Bench-Scale Reactor to Tidd Operating Conditions

\begin{tabular}{lcc}
\hline Project & Tidd & EERC Run M280 \\
\hline Coal & Ohio bituminous & Center lignite \\
Coal Sulfur & $4 \%$ & $0.7 \%$ \\
Coal Ash & $10 \%$ & $8 \%$ \\
Coal Feed & Paste & Dry, $36 \%$ Moisture \\
Sorbent Feed & Dry & Dry \\
Sorbent & Dolomite & Limestone \\
Sorbent Size & -3200 micron & -3360 to +420 micron \\
& $-1 / 8$ inch & -6 to $+40 \mathrm{mesh}$ \\
Excess Air & $25 \%$ & $20 \%$ \\
Fluidizing Velocity & $0.9 \mathrm{~m} / \mathrm{s}$ & $0.49 \mathrm{~m} / \mathrm{s}$ \\
Bed Height & $3.5 \mathrm{~m}$ & $0.84 \mathrm{~m}$ \\
Residence Time & $3.95 \mathrm{~s}$ & $1.71 \mathrm{~s}$ \\
Bed Temperature & $840^{\circ} \mathrm{C}$ & $850^{\circ} \mathrm{C}$ \\
Pressure & $12 \mathrm{bar}$ & $6.9 \mathrm{bar}$ \\
Coal Feed Rate & $7.2 \mathrm{~kg} / \mathrm{s}$ & $(1.75 \mathrm{~kg} / \mathrm{hr}) 4.9 \times 10^{-4} \mathrm{~kg} / \mathrm{hr}$ \\
Sorbent Feed Rate & $2.3 \mathrm{~kg} / \mathrm{s}$ & $(.062 \mathrm{~kg} / \mathrm{hr}) 1.7 \times 10^{-5} \mathrm{~kg} / \mathrm{hr}$ \\
Coal/Sorbent & $3.13 \mathrm{~kg} / \mathrm{kg}$ & $28.3 \mathrm{~kg} / \mathrm{kg}$ \\
Ca/S Molar Ratio & $1.6 \mathrm{to} 1.8$ & 2.2 \\
Sulfur Retention & $90 \%$ & $48 \%$ \\
Alkali Utilization & $50 \%$ & $6 \%$ \\
\hline & & \\
\hline & &
\end{tabular}


TABLE 7

CCSEM Data for the Center Blend Coal

(Weight Percent of Mineral Matter Analyzed)

\begin{tabular}{|c|c|c|c|c|c|c|c|}
\hline Diameter, $\mu \mathrm{m}:$ & 1.0 to 2.2 & 2.2 to 4.6 & 4.6 to 10.0 & 10.0 to 22.0 & 22.0 to 46.0 & 46.0 to 100.0 & Totals \\
\hline Quartz & 3.0 & 3.6 & 1.9 & 2.2 & .9 & .9 & 12.4 \\
\hline Iron Oxide & .4 & .7 & .5 & .3 & .0 & .0 & 1.8 \\
\hline Periclase & .0 & .0 & .0 & .0 & .0 & .0 & .0 \\
\hline Rutile & .1 & .0 & .0 & .1 & .0 & .0 & .2 \\
\hline Alumina & .0 & .0 & .0 & .0 & .0 & .0 & .0 \\
\hline Calcite & .0 & .1 & .0 & .1 & .0 & .0 & .2 \\
\hline Dolomite & .0 & .0 & .0 & .1 & .0 & .0 & .1 \\
\hline Ankerite & .0 & .0 & .0 & .0 & .0 & .0 & .0 \\
\hline Kaolinite & 1.2 & 1.1 & .0 & .8 & .0 & .6 & 3.7 \\
\hline Montmorillonite & .3 & .6 & .2 & .1 & .0 & .0 & 1.2 \\
\hline K Al-Silicate & .2 & .2 & .0 & .2 & .0 & .0 & .6 \\
\hline Fe Al-Silicate & .1 & .0 & .0 & .1 & .0 & .0 & .2 \\
\hline Ca Al-Silicate & .1 & .1 & .0 & .0 & .0 & .0 & .2 \\
\hline Na Al-Silicate & .0 & .0 & .0 & .1 & .0 & .0 & .1 \\
\hline Aluminosilicate & .5 & .2 & .7 & .1 & .0 & .0 & 1.5 \\
\hline Mixed Al-Silica & .0 & .0 & .0 & .0 & .0 & .0 & .0 \\
\hline Fe Silicate & .0 & .0 & .0 & .0 & .0 & .0 & .0 \\
\hline Ca Silicate & .0 & .0 & .0 & .0 & .0 & .0 & .0 \\
\hline $\mathrm{Ca}$ Aluminate & .0 & .0 & .0 & .0 & .0 & .0 & .0 \\
\hline Pyrite & 13.7 & 14.7 & 9.2 & 11.0 & 10.3 & .0 & 58.9 \\
\hline Pyrrhotite & .0 & .1 & .0 & .0 & .0 & .0 & .1 \\
\hline Oxidized Pyrrhotite & .1 & .1 & 2.5 & .0 & .0 & .0 & 2.7 \\
\hline Gypsum & .4 & .5 & .2 & .1 & .0 & .0 & 1.2 \\
\hline Barite & .8 & 1.3 & 1.4 & .6 & .2 & .0 & 40.3 \\
\hline Apatite & .0 & .0 & .0 & $: 0$ & .0 & .0 & .0 \\
\hline Ca Al-P & .4 & .7 & .0 & .0 & .0 & .0 & 1.1 \\
\hline $\mathrm{KCl}$ & .0 & .0 & .0 & .0 & .0 & .0 & .0 \\
\hline Gypsum/Barite & .1 & .0 & .0 & .0 & .0 & .0 & .1 \\
\hline Gypsum/Al-Silicate & .1 & .0 & .0 & .0 & .0 & .0 & .1 \\
\hline Si-Rich & .4 & .7 & .4 & .4 & .1 & .0 & 2.0 \\
\hline Ca-Rich & .0 & .0 & .0 & .0 & .2 & .0 & .2 \\
\hline Ca-Si-Rich & .0 & .0 & .0 & .0 & .0 & .0 & .0 \\
\hline Unknown & 2.9 & 1.9 & 1.7 & .5 & .1 & .0 & 7.1 \\
\hline Totals & 24.7 & 26.5 & 18.8 & 16.7 & 11.8 & 1.5 & 100.0 \\
\hline
\end{tabular}


TABLE 8

Chemical Fractionation Data for the Center Blend Coal, wt\%

\begin{tabular}{lrrrcrcr}
\hline & $\begin{array}{c}\text { Initial } \\
(\mathrm{ppm})\end{array}$ & As Oxides & $\begin{array}{c}\text { Removed } \\
\text { by } \mathrm{H}_{2} \mathrm{O}\end{array}$ & $\begin{array}{c}\text { Removed by } \\
\mathrm{NH}_{4} \mathrm{OAc}\end{array}$ & $\begin{array}{c}\text { Removed } \\
\text { by } \mathrm{HCl}\end{array}$ & Remaining \\
\hline Silicon & 6,600 & 14,000 & 0 & 0 & 0 & 100 \\
Aluminum & 3,100 & 5,900 & 0 & 0 & 0 & 100 \\
Iron & 5,600 & 8,000 & 10 & 0 & 0 & 90 \\
Titanium & 190 & 320 & 0 & 0 & 12 & 88 \\
Phosphorus & 170 & 400 & 0 & 0 & 100 & 0 \\
Calcium & 12,000 & 17,000 & 0 & 48 & 51 & 1 \\
Magnesium & 4,500 & 7,400 & 0 & 59 & 32 & 9 \\
Sodium & 2,200 & 3,000 & 18 & 79 & 3 & 0 \\
Potassium & 260 & 320 & 24 & 43 & 0 & 33 \\
\hline
\end{tabular}




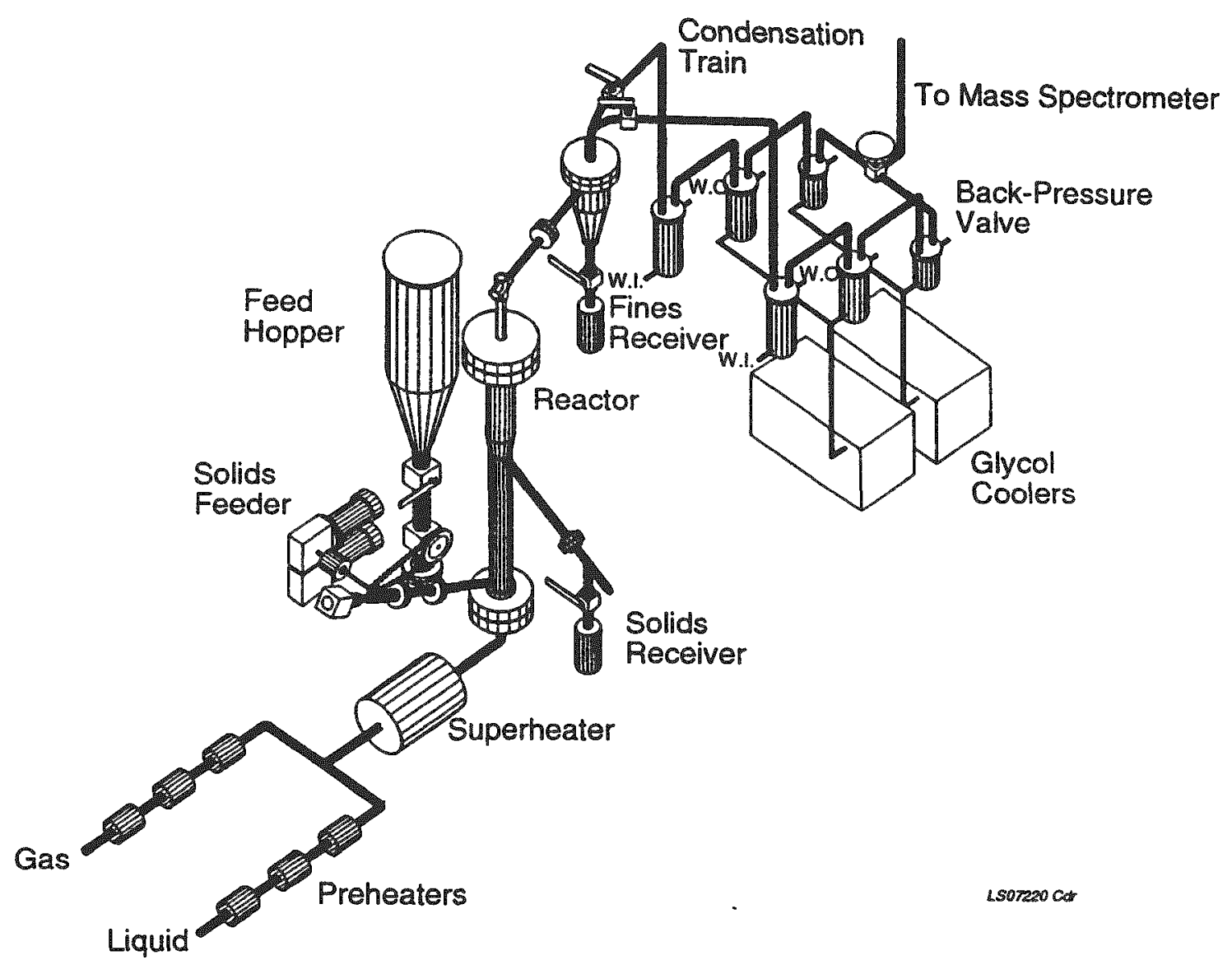

Figure 1. 4-lb/hr pressurized fluid-bed reactor (PFBR). 


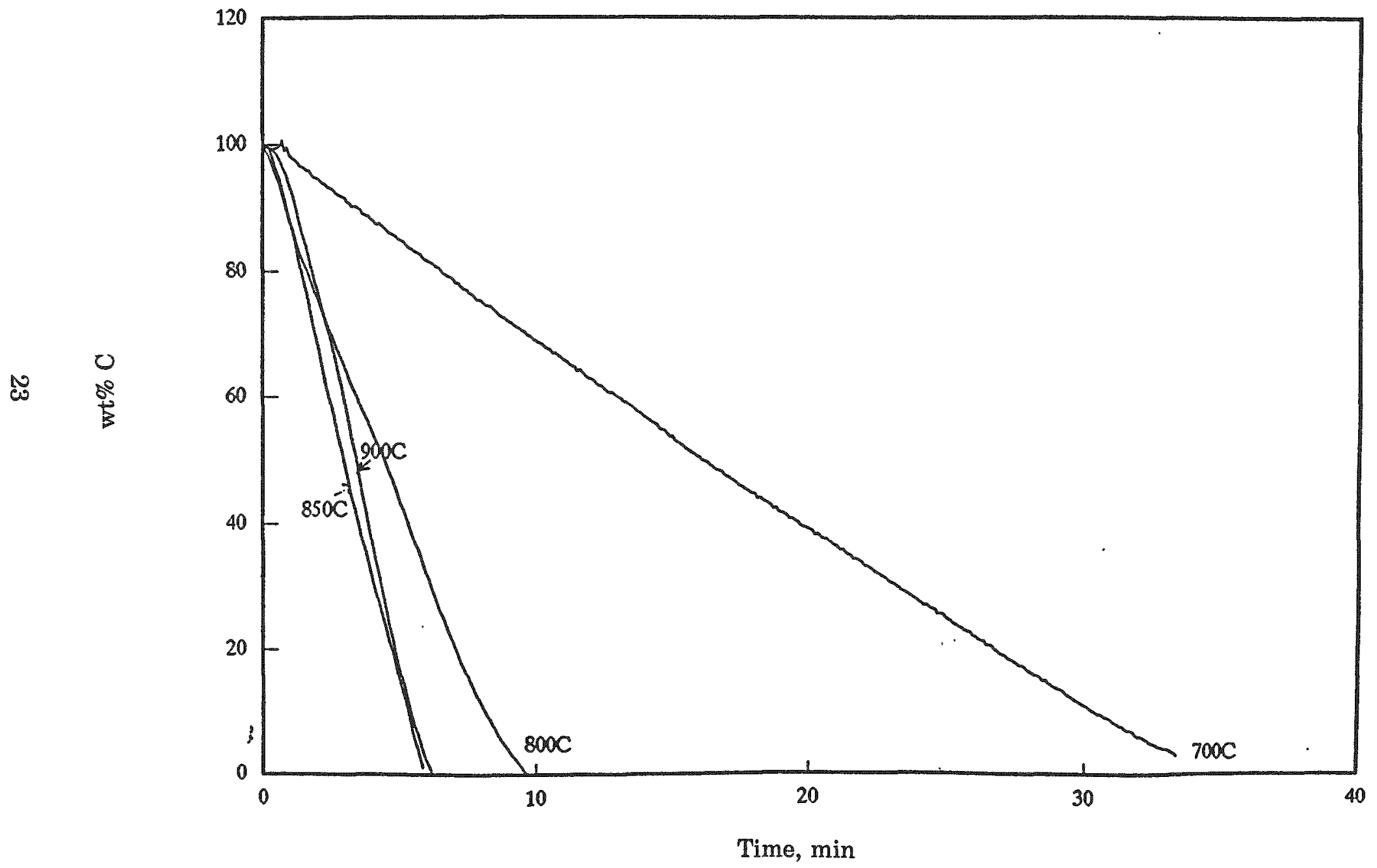

Figure 2. Steam reactivity. 


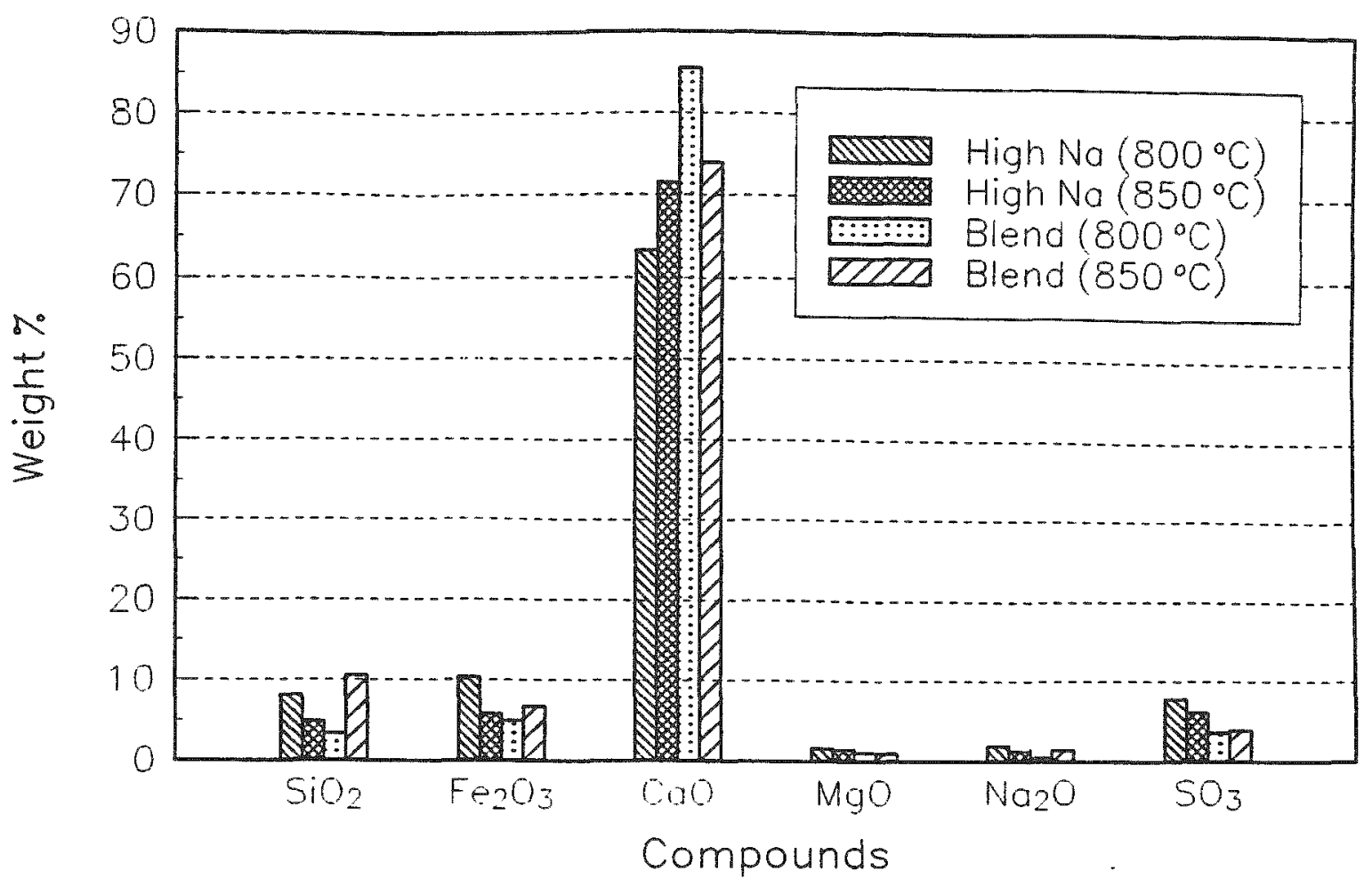

Figure 3. The major element compositions of agglomerates and bed materials from the high-sodium and blend tests at $800^{\circ}$ and $850^{\circ} \mathrm{C}$.

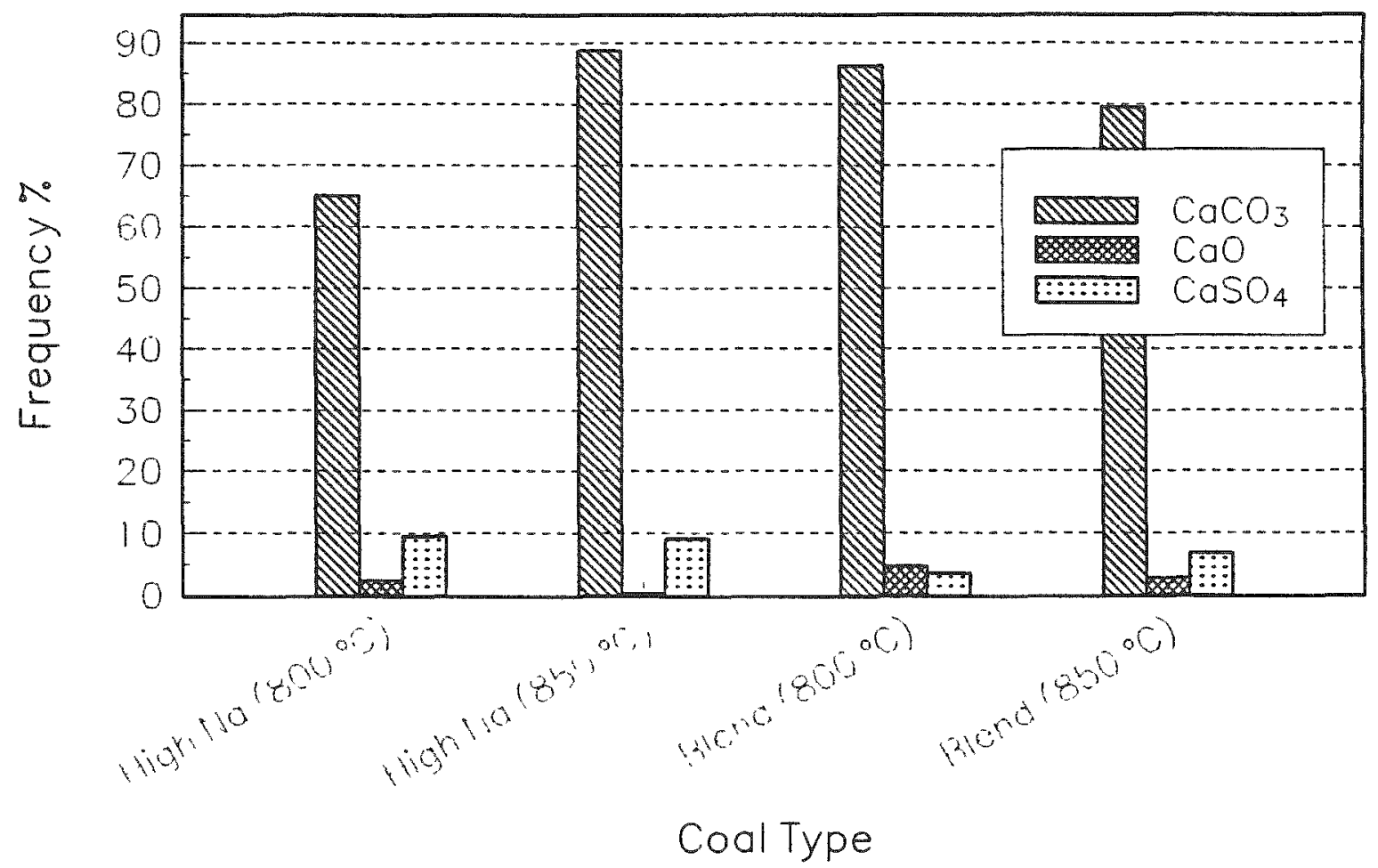

Figure 4. The quantities of calcite (limestone), calcium oxide (calcined limestone), and calcium sulfate in the bed material from the high-sodium and blend tests at $800^{\circ}$ and $850^{\circ} \mathrm{C}$. 


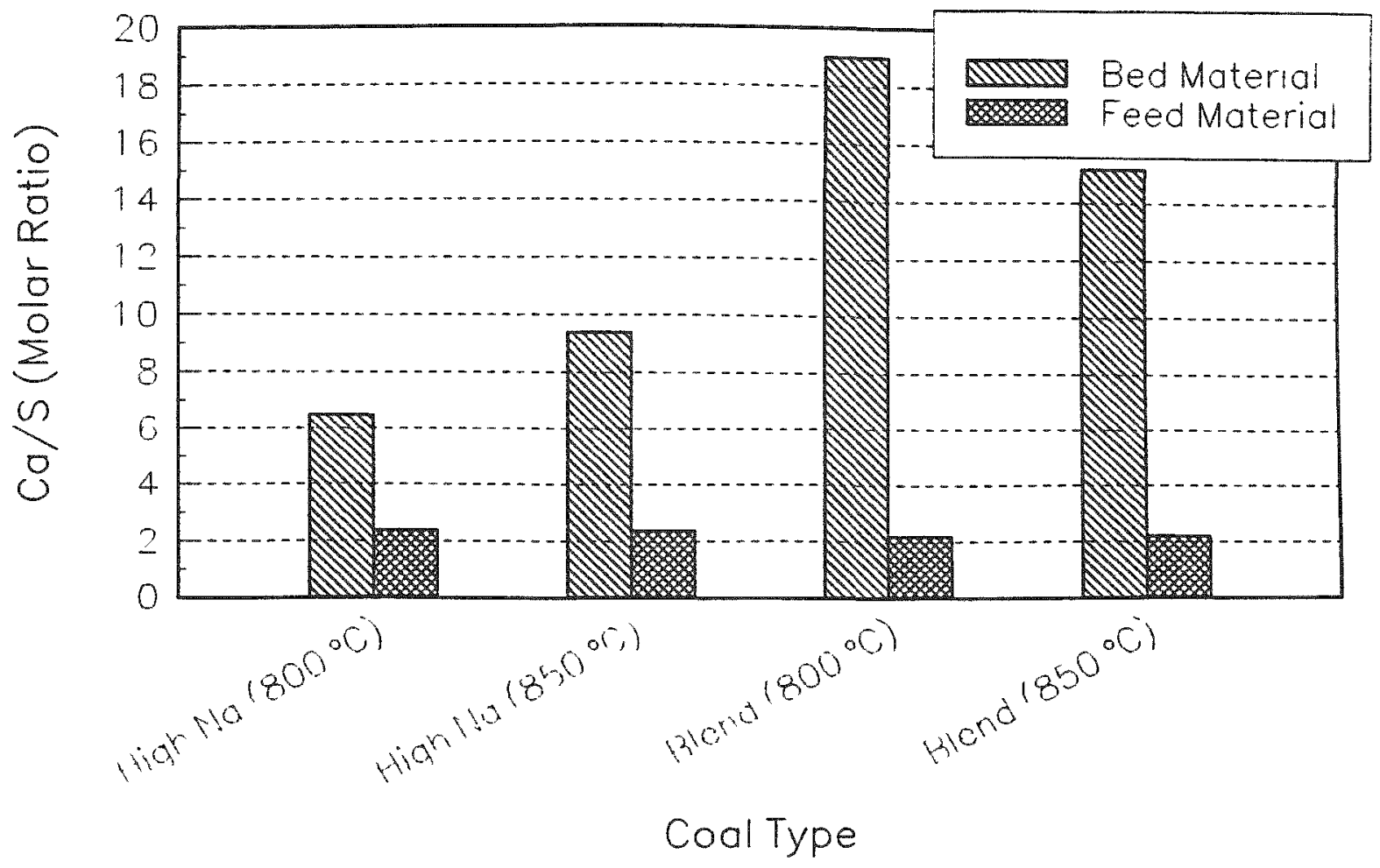

Figure 5. The input versus measured $\mathrm{Ca} / \mathrm{S}$ ratios in the agglomerates and bed materials from the high-sodium and blend tests at $800^{\circ}$ and $850^{\circ} \mathrm{C}$.

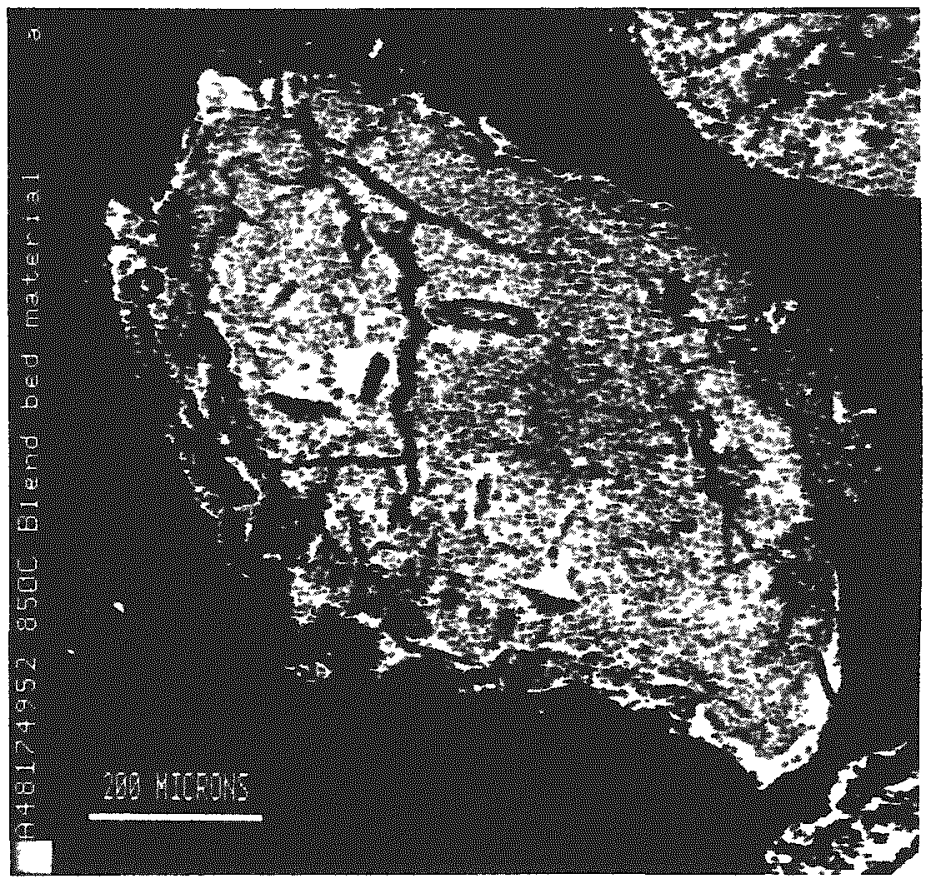

Figure 6. SEM photograph of a cross section of a typical limestone particle remaining in the bed of the $850^{\circ} \mathrm{C}$ blended coal gasification test. 


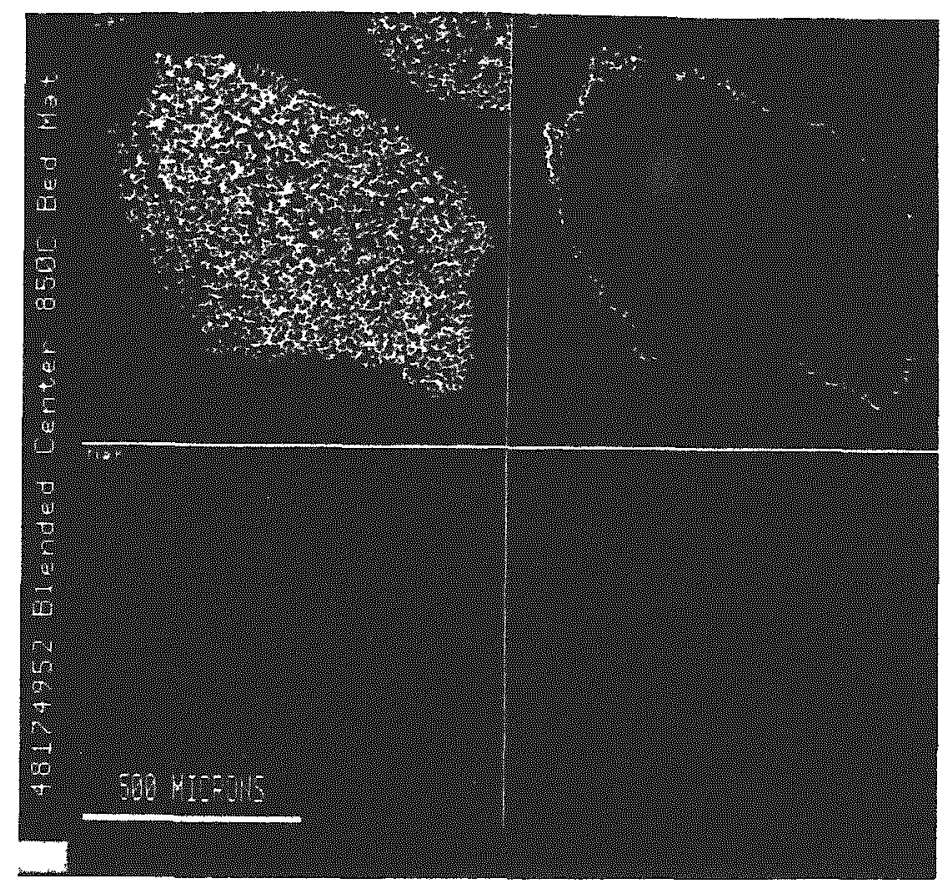

Figure 7. Composition maps of calcium, sulfur, and sodium for the limestone particle shown in Figure 6.

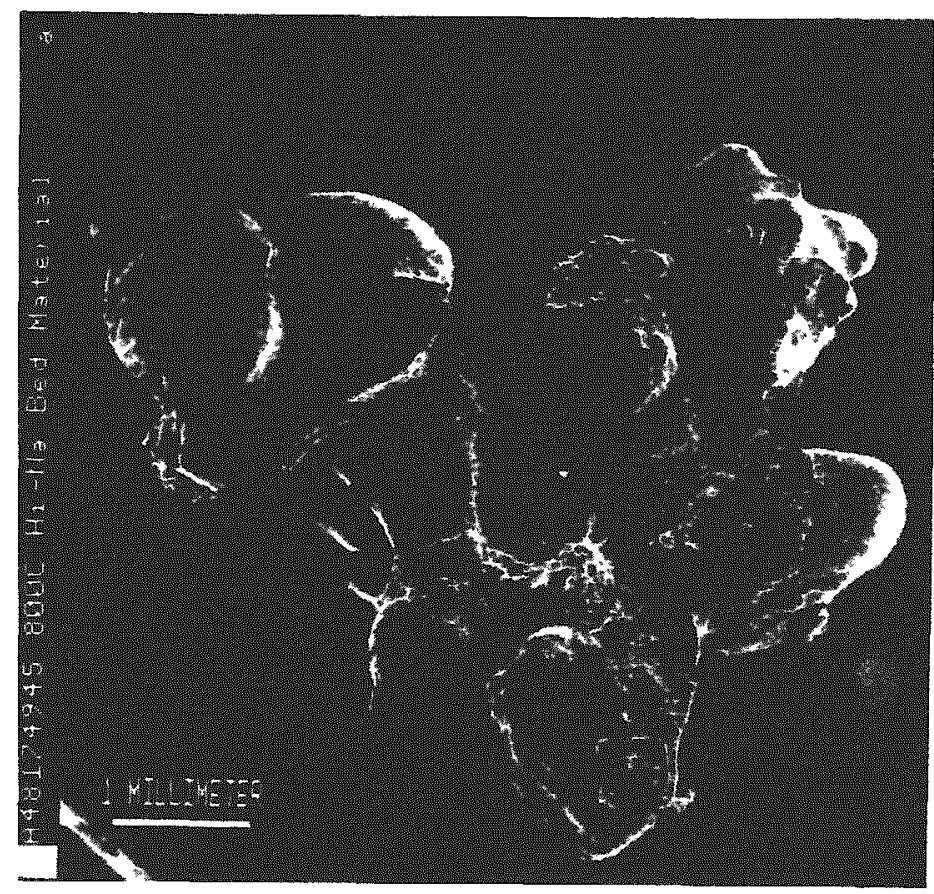

Figure 8. A portion of an agglomerate that formed during the $800^{\circ} \mathrm{C}$ high-sodium test. 


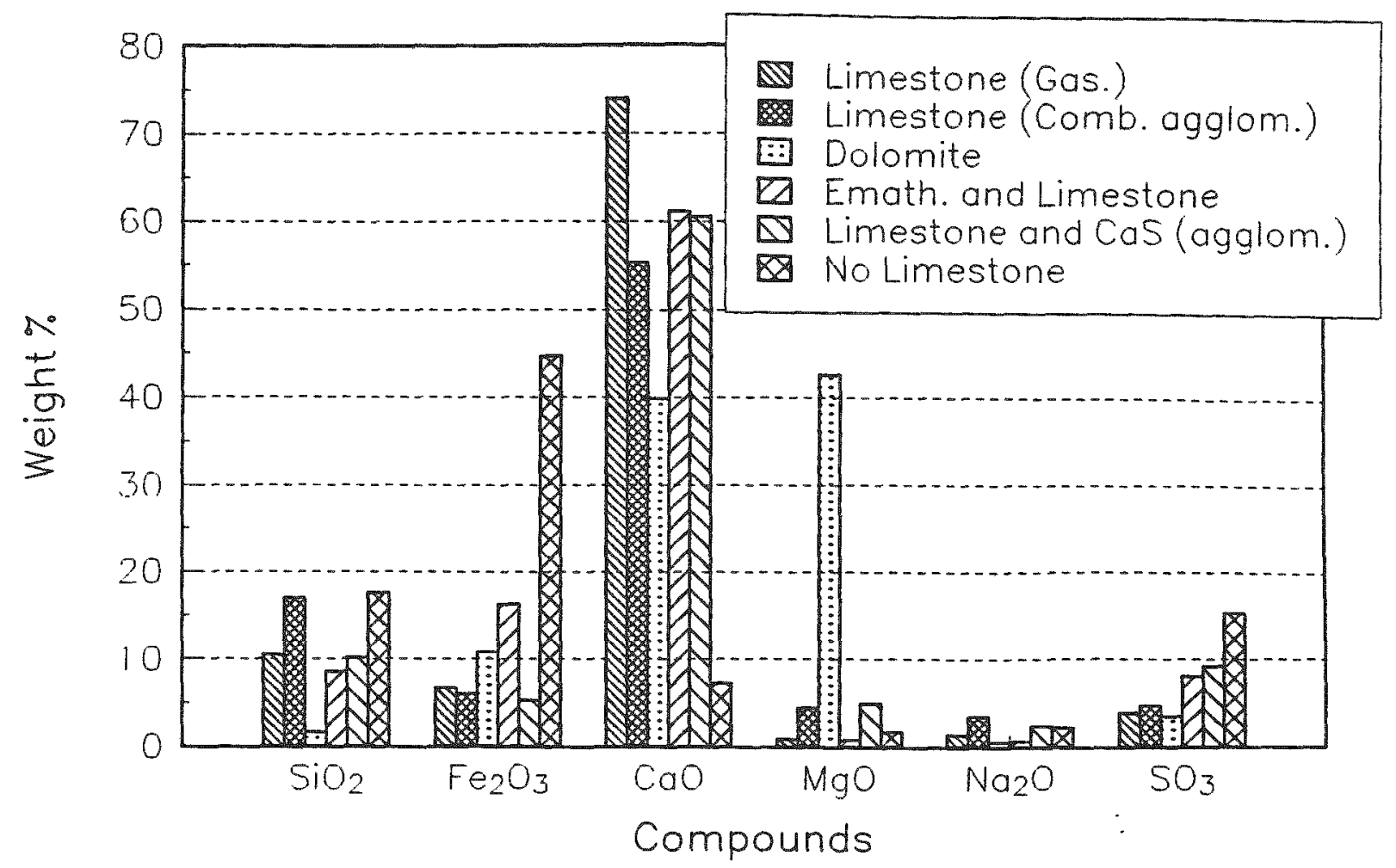

Figure 9. The major element compositions of the bed materials from the tests of different bed materials under gasification or combustion conditions.

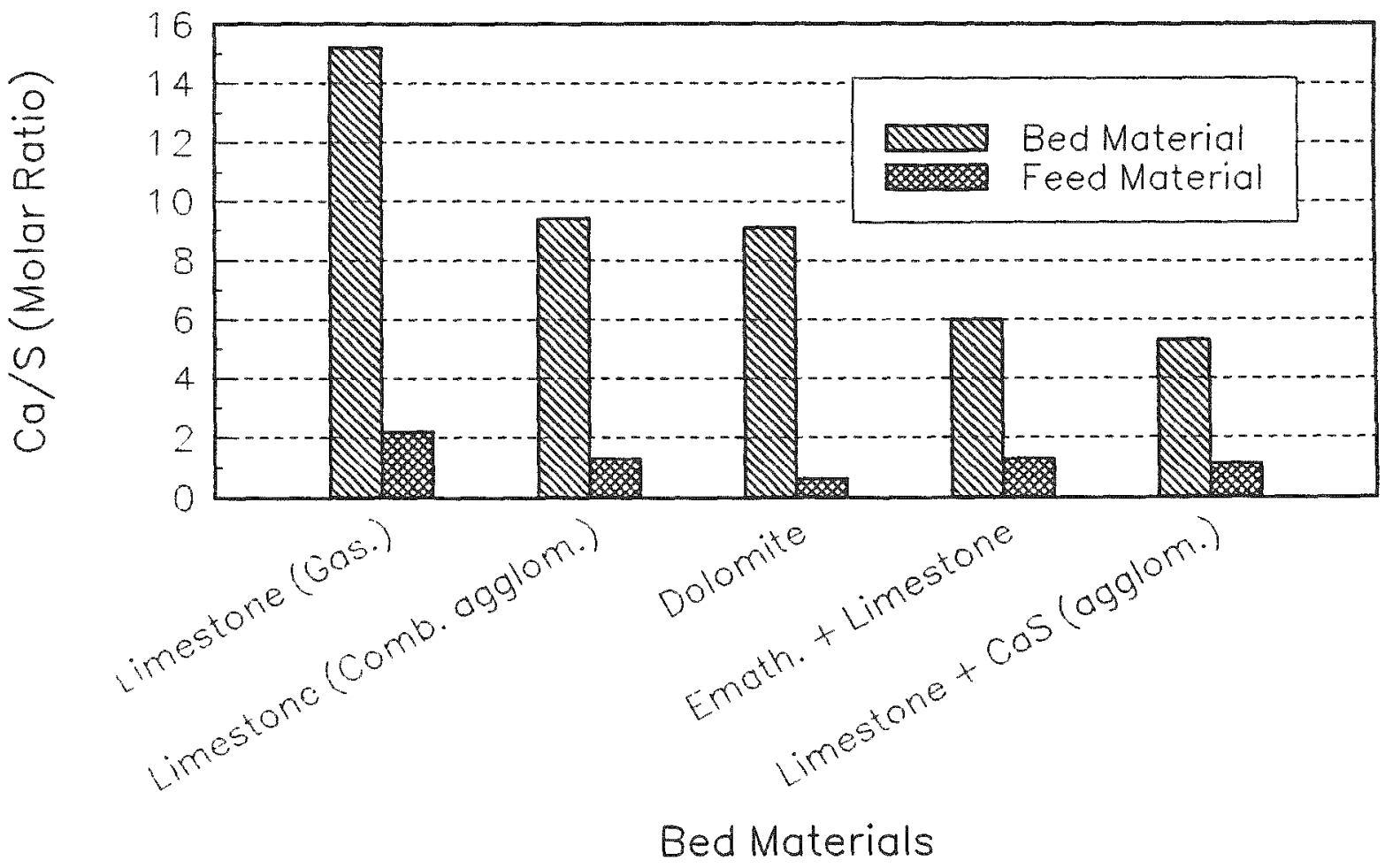

Figure 10. The input versus measured $\mathrm{Ca} / \mathrm{S}$ ratios in the bed materials from tests of different bed materials under gasification or combustion conditions. 


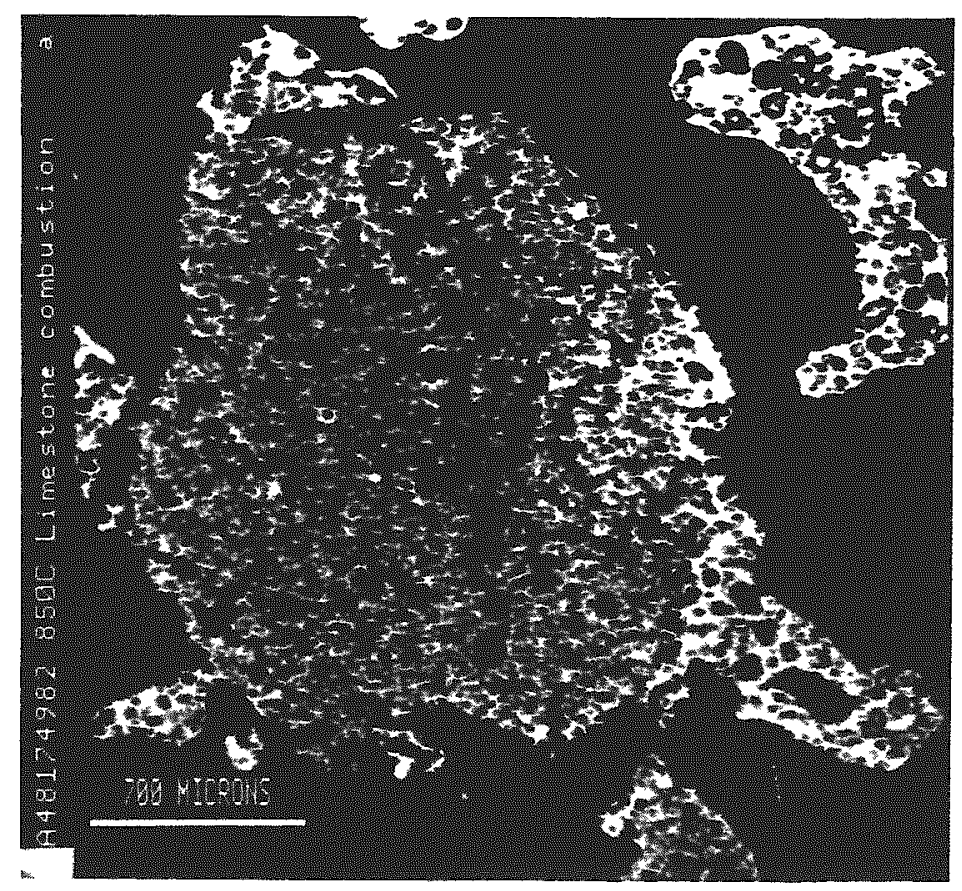

Figure 11. SEM photograph of a cross section of a typical limestone particle remaining in the bed of the $850^{\circ} \mathrm{C}$ blended coal combustion test.

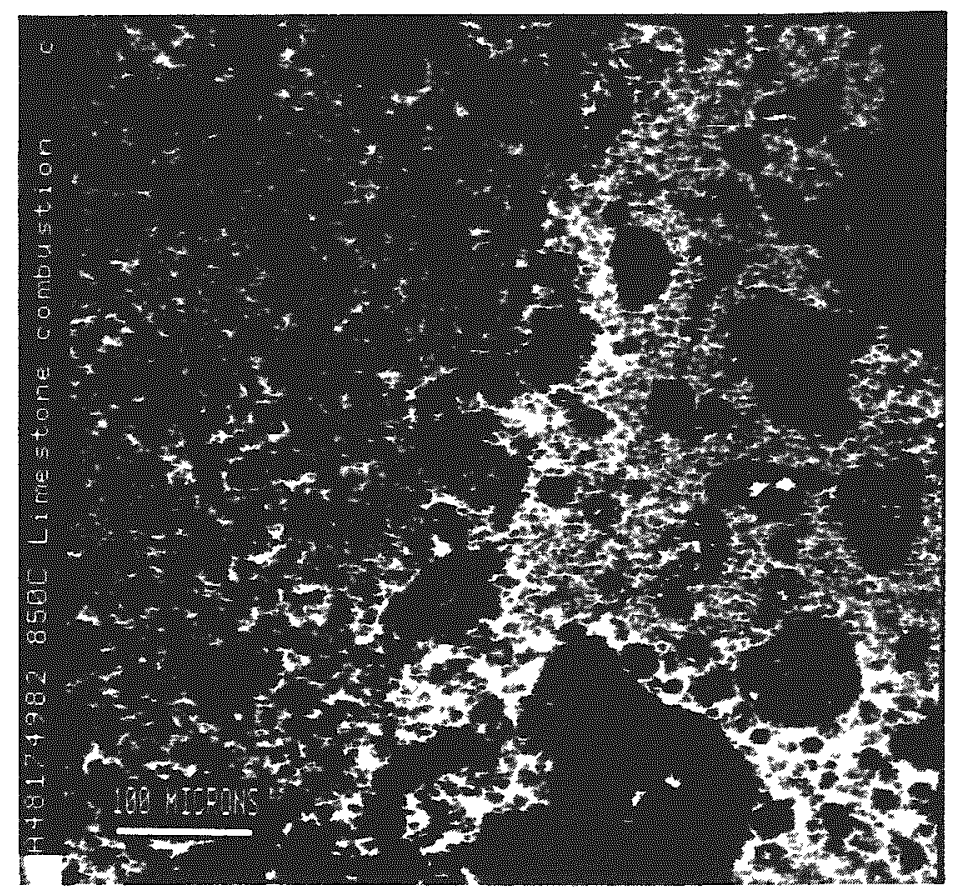

Figure 12. A close-up of the particle in Figure 11 showing its microporous nature and morphology variations. 


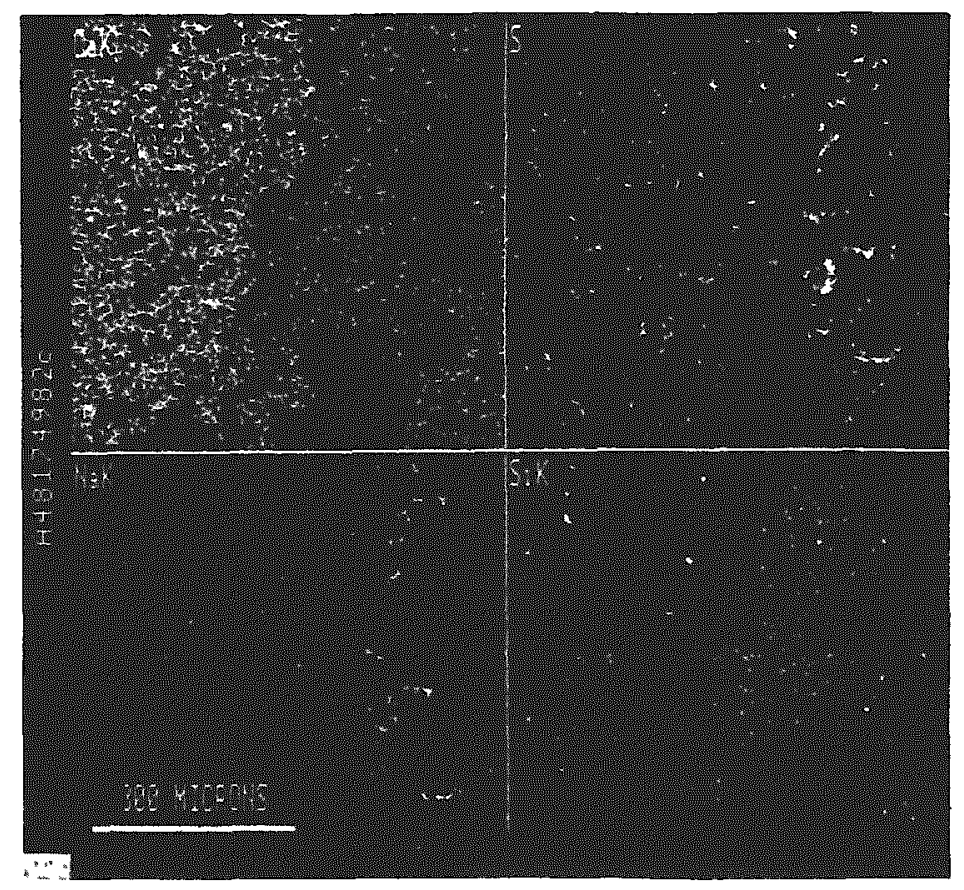

Figure 13. Composition maps of calcium, sulfur, sodium, and silicon for the particle shown in Figure 12.

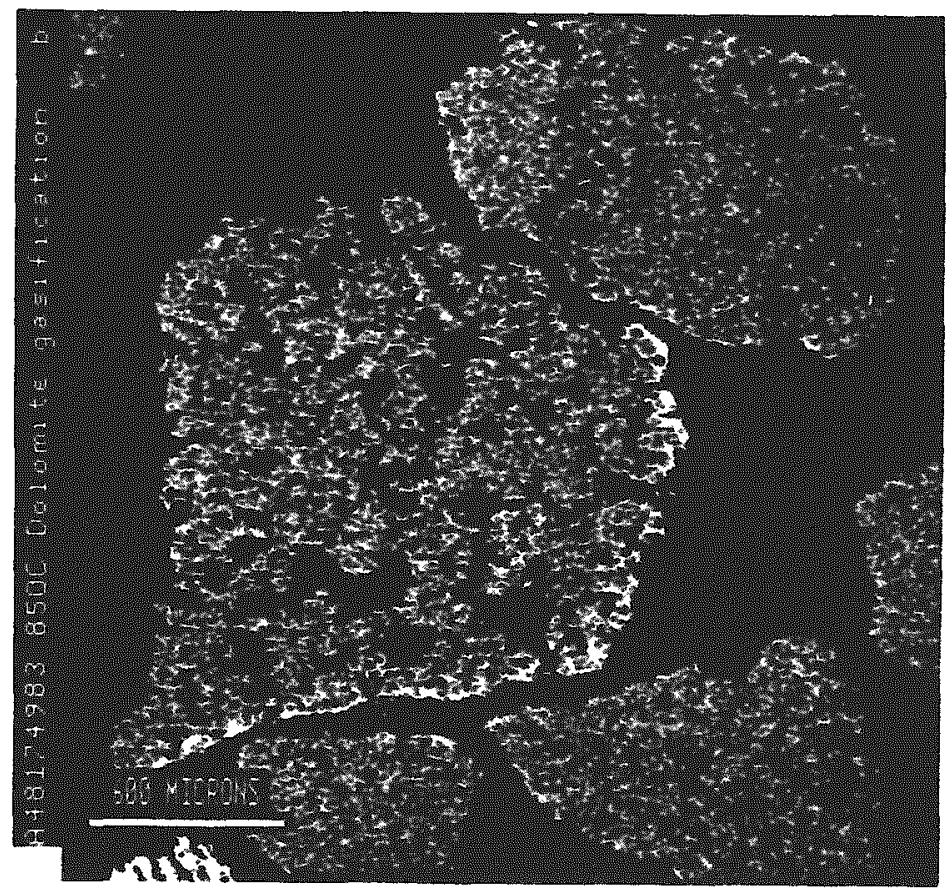

Figure 14. SEM photograph of a cross section of a typical dolomite particle remaining in the bed of the $850^{\circ} \mathrm{C}$ blended coal gasification test. 


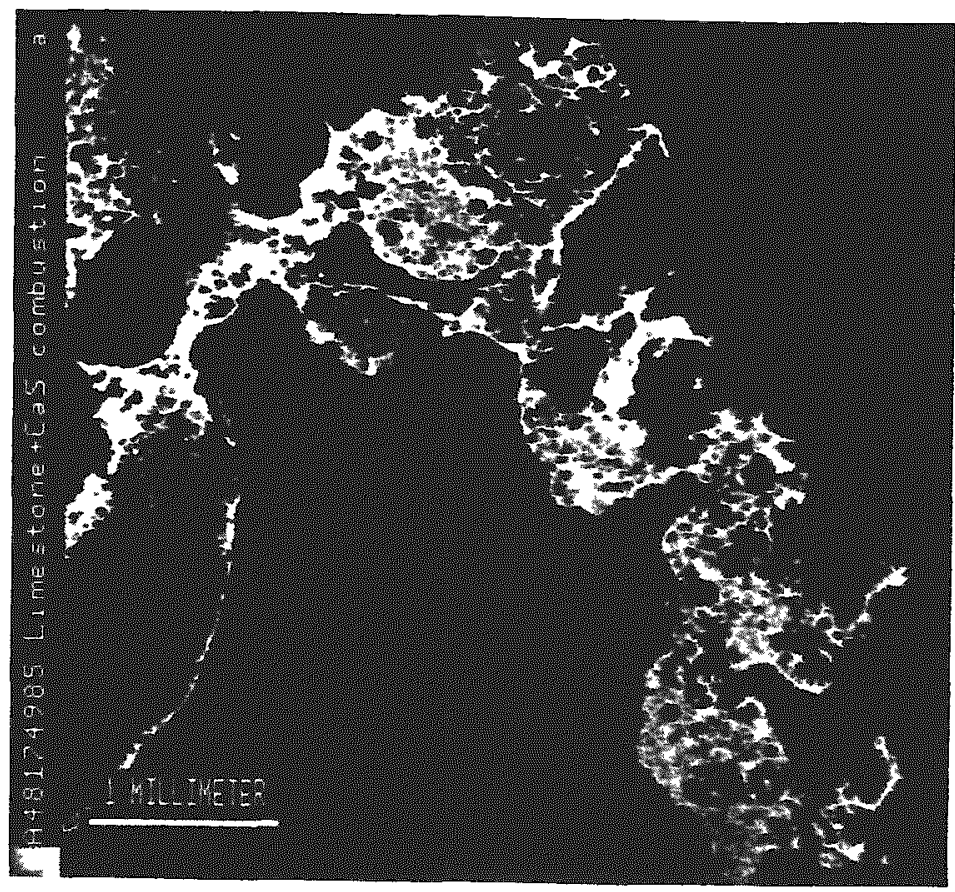

Figure 15. SEM photograph of a cross section of a portion of an agglomerate from the CaS addition test showing the relationship between the bright binder material and the residual bed particles that are cemented by it. 
APPENDIX A

EXTENDED MATERIAL BALANCE SHEETS 
Appendix A contains the extended material balance sheets. On these extended material balance sheets, product yields are calculated, as well as "normalized product yields." In most cases, closure and, therefore, total yield is not $100 \%$. The difference between mass in and mass out is distributed among product streams to ensure a total product yield of $100 \%$. In determining the material balances, the elements (ash and nitrogen) are balanced. Total material in and out are summed and the difference between the two noted. For example, in M262, 75,600 grams of material were fed to the system and 74,973 grams of material were collected ( $99.2 \%$ closure). The difference between the two is 627 grams. This 627 grams is distributed to one or more of the four product streams (cyclone char, top bed drain char, liquids, and gas) based on the ash and nitrogen balances. In M262, ash in is 427.3 and ash out is $428.8 \mathrm{~g}$. No material is given to either char stream since these two numbers are within $1 \%$ of each other. An examination of the nitrogen balance indicates that we are short some nitrogen. This shortage could occur either from a leak or when sampling gas for GC or IR analyses. The gas stream accounts for $89 \%$ of the 627 grams (558 grams); this 558 grams is distributed on a molar basis to the components of the product gas stream. The last $11 \%$ of the "missing mass" is allocated to the liquid stream, which, in this case, is water.

The other difference between the extended material balance sheets and the conversion table is the basis used for char and coal in/out. In the conversion table, total coal in and char out are listed. In the extended material balance sheets, everything is done on a maf (moisture- and ash-free) basis. 


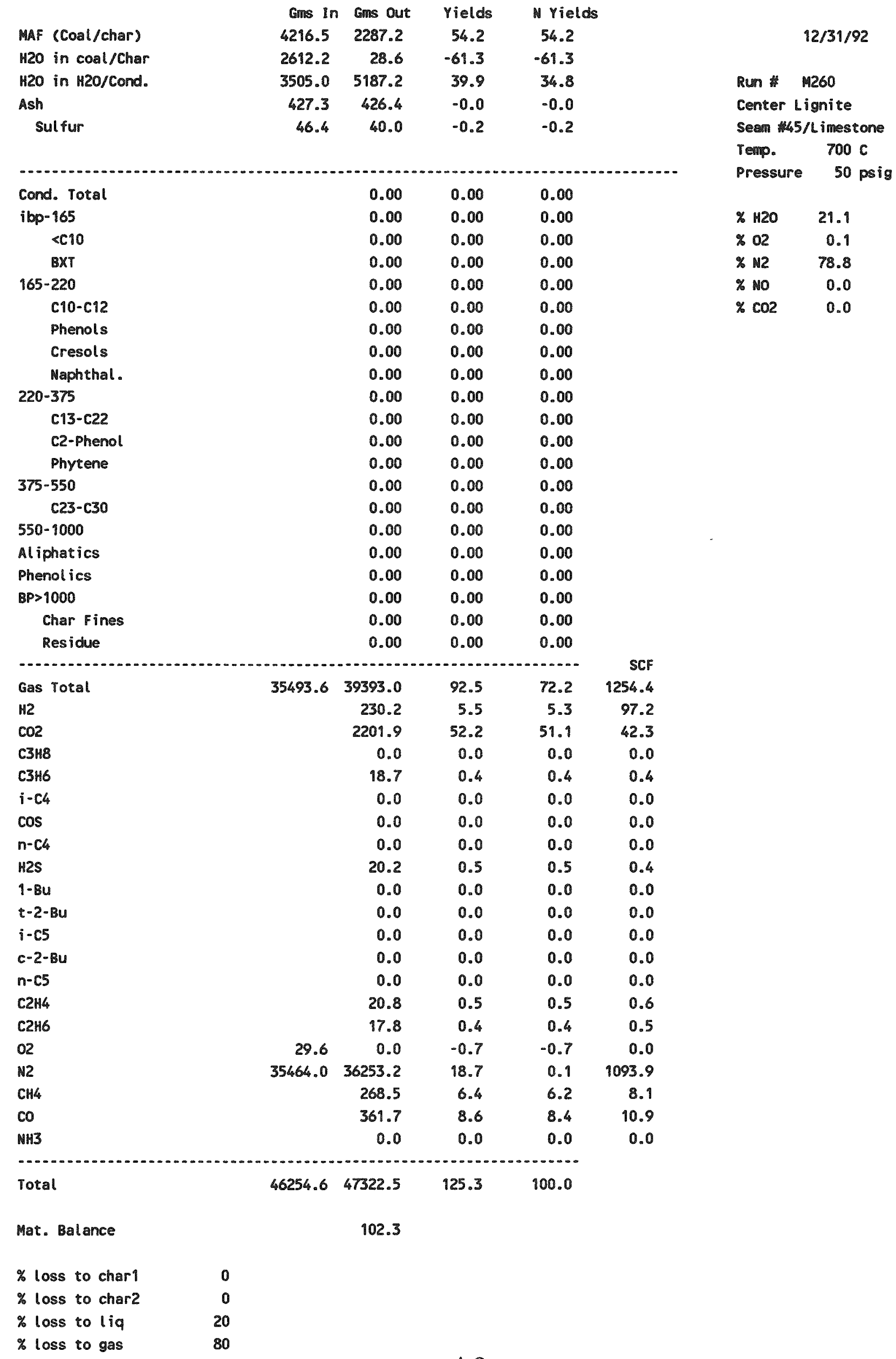




$\begin{array}{lrrrc} & \text { Gms In } & \text { Gns Out } & \text { Yields } & \text { N Vields } \\ \text { MAF (Coal/char) } & 4216.5 & 411.5 & 9.8 & 9.8 \\ \text { H2O in coal/Char } & 2612.2 & 23.4 & -61.4 & -61.4 \\ \text { H2O in H20/Cond. } & 6316.0 & 5921.3 & -9.4 & 6.9 \\ \text { Ash } & 427.3 & 429.5 & 0.1 & 0.1 \\ \quad \text { Sulfur } & 45.4 & 30.3 & -0.4 & -0.4\end{array}$

\begin{tabular}{|c|c|c|c|}
\hline Cond. Total & 0.00 & 0.00 & 0.00 \\
\hline ibp- 165 & 0.00 & 0.00 & 0.00 \\
\hline$<C 10$ & 0.00 & 0.00 & 0.00 \\
\hline BXT & 0.00 & 0.00 & 0.00 \\
\hline $165-220$ & 0.00 & 0.00 & 0.00 \\
\hline c10-c12 & 0.00 & 0.00 & 0.00 \\
\hline Phenols & 0.00 & 0.00 & 0.00 \\
\hline Cresols & 0.00 & 0.00 & 0.00 \\
\hline Naph thal. & 0.00 & 0.00 & 0.00 \\
\hline $220-375$ & 0.00 & 0.00 & 0.00 \\
\hline $\mathrm{c} 13-\mathrm{c} 22$ & 0.00 & 0.00 & 0.00 \\
\hline c2-Phenol & 0.00 & 0.00 & 0.00 \\
\hline Phytene & 0.00 & 0.00 & 0.00 \\
\hline $375-550$ & 0.00 & 0.00 & 0.00 \\
\hline $\operatorname{c23}-\mathrm{c30}$ & 0.00 & 0.00 & 0.00 \\
\hline $550-1000$ & 0.00 & 0.00 & 0.00 \\
\hline Aliphatics & 0.00 & 0.00 & 0.00 \\
\hline Phenolics & 0.00 & 0.00 & 0.00 \\
\hline$B P>1000$ & 0.00 & 0.00 & 0.00 \\
\hline Char fines & 0.00 & 0.00 & 0.00 \\
\hline Residue & 0.00 & 0.00 & 0.00 \\
\hline
\end{tabular}

Run M261

Center Lignite

Sean $45 /$ Limest

Temp. 800

Pressure 100

\% H2O 17.4

\% $02 \quad 2.4$

\% M2 80.2

\% MO 0.0

* $\mathrm{CO2} \quad 0.0$

\begin{tabular}{|c|c|c|c|c|c|}
\hline Gas Total & 66133.5 & 71899.0 & 136.7 & 944.7 & 2335.3 \\
\hline H2 & & 426.7 & 10.1 & 10.2 & 185.1 \\
\hline $\mathrm{CO} 2$ & & 5716.8 & 135.6 & 136.2 & 112.7 \\
\hline CЗH8 & & 0.0 & 0.0 & 0.0 & 0.0 \\
\hline C3H6 & & 0.0 & 0.0 & 0.0 & 0.0 \\
\hline$i-c_{4}$ & & 0.0 & 0.0 & 0.0 & 0.0 \\
\hline $\cos$ & & 0.0 & 0.0 & 0.0 & 0.0 \\
\hline$n-C_{4}$ & & 0.0 & 0.0 & 0.0 & 0.0 \\
\hline H2S & & 18.2 & 0.4 & 0.4 & 0.4 \\
\hline $1-B u$ & & 0.0 & 0.0 & 0.0 & 0.0 \\
\hline$t-2-8 u$ & & 0.0 & 0.0 & 0.0 & 0.0 \\
\hline$i-c 5$ & & 0.0 & 0.0 & 0.0 & 0.0 \\
\hline$c-2-8 u$ & & 0.0 & 0.0 & 0.0 & 0.0 \\
\hline$n-c 5$ & & 0.0 & 0.0 & 0.0 & 0.0 \\
\hline $\mathrm{C}_{2} \mathrm{H}_{4}$ & & 52.4 & 9.2 & 1.2 & 1.6 \\
\hline C2N6 & & 0.0 & 0.0 & 0.0 & 0.0 \\
\hline 02 & 2175.0 & 0.0 & -51.6 & -51.6 & 0.0 \\
\hline N2 & 63958.5 & 63657.4 & -7.1 & -0.1 & 1972.6 \\
\hline $\mathrm{CH}_{4}$ & & 490.6 & 9.7 & 9.8 & 12.7 \\
\hline CO & & 1616.9 & 38.3 & 38.5 & 50.1 \\
\hline MHS & & 0.0 & 0.0 & 0.0 & 0.0 \\
\hline Total & 79705.5 & 78684.7 & 75.8 & 100.0 & \\
\hline
\end{tabular}

Mat. Balance

98.7

$\begin{array}{lr}\text { \% loss to char1 } & 0 \\ \% \text { loss to char2 } & 0 \\ \% \text { loss to Iiq } & 67 \\ \text { \% loss to gas } & 33\end{array}$




$\begin{array}{lrrrc}\text { MAF (Coal/char) } & \text { Gns In } & \text { Gns out } & \text { Yields } & \text { N Yields } \\ \text { H20 in coal/Char } & 4216.5 & 394.6 & 9.4 & 9.4 \\ \text { H20 in H2O/Cond. } & 2612.2 & 22.7 & -61.4 & -61.4 \\ \text { Ash } & 4605.0 & 4644.1 & 0.9 & 2.6 \\ \text { Sulfur } & 427.3 & 428.8 & 0.0 & 0.0 \\ & 46.4 & 23.9 & -0.5 & -0.5\end{array}$

\begin{tabular}{llll} 
Cond. Total & 0.00 & 0.00 & 0.00 \\
ibp-165 & 0.00 & 0.00 & 0.00 \\
<c10 & 0.00 & 0.00 & 0.00 \\
BXT & 0.00 & 0.00 & 0.00 \\
$165-220$ & 0.00 & 0.00 & 0.00 \\
C10-c12 & 0.00 & 0.00 & 0.00 \\
Phenols & 0.00 & 0.00 & 0.00 \\
Cresols & 0.00 & 0.00 & 0.00 \\
Naphthal. & 0.00 & 0.00 & 0.00 \\
220-375 & 0.00 & 0.00 & 0.00 \\
C13-C22 & 0.00 & 0.00 & 0.00 \\
C2-Phenol & 0.00 & 0.00 & 0.00 \\
Phytene & 0.00 & 0.00 & 0.00 \\
375-550 & 0.00 & 0.00 & 0.00 \\
C23-C30 & 0.00 & 0.00 & 0.00 \\
550-1000 & 0.00 & 0.00 & 0.00 \\
Aliphatics & 0.00 & 0.00 & 0.00 \\
Phenolics & 0.00 & 0.00 & 0.00 \\
BP>1000 & 0.00 & 0.00 & 0.00 \\
Char Fines & 0.00 & 0.00 & 0.00 \\
Residue & 0.00 & 0.00 & 0.00 \\
\hline - & &
\end{tabular}

Run 1262

Center Ligni te Seam $5 /$ Limestone Temp. $850 \mathrm{C}$ Pressure 100 psig \% $120 \quad 15.0$ \% $02 \quad 2.2$

\% N2 82.5

$\%$ NO 0.0 $\% \operatorname{co} 2 \quad 0.0$

\begin{tabular}{|c|c|c|c|c|c|}
\hline Gas Total & 63739.3 & 69483.1 & 136.2 & 149.5 & 2260.7 \\
\hline H2 & & 397.3 & 9.4 & 9.5 & 172.8 \\
\hline $\mathrm{CO} 2$ & & 5319.5 & 126.2 & 127.2 & 105.2 \\
\hline C3H8 & & 0.0 & 0.0 & 0.0 & 0.0 \\
\hline C3H6 & & 0.0 & 0.0 & 0.0 & 0.0 \\
\hline $\mathrm{i}-\mathrm{CL}_{4}$ & & 0.0 & 0.0 & 0.0 & 0.0 \\
\hline $\cos$ & & 0.0 & 0.0 & 0.0 & 0.0 \\
\hline$n-C 4$ & & 0.0 & 0.0 & 0.0 & 0.0 \\
\hline H2S & & 0.0 & 0.0 & 0.0 & 0.0 \\
\hline 1-Bu & & 0.0 & 0.0 & 0.0 & 0.0 \\
\hline$t-2-B u$ & & 0.0 & 0.0 & 0.0 & 0.0 \\
\hline$i-c 5$ & & 0.0 & 0.0 & 0.0 & 0.0 \\
\hline$c-2-B u$ & & 0.0 & 0.0 & 0.0 & 0.0 \\
\hline$n=c 5$ & & 0.0 & 0.0 & 0.0 & 0.0 \\
\hline $\mathrm{C} 2 \mathrm{H} 4$ & & 86.8 & 2.1 & 2.1 & 2.7 \\
\hline C2N6 & & 0.0 & 0.0 & 0.0 & 0.0 \\
\hline 02 & 1914.2 & 0.0 & -45.4 & -45.4 & 0.0 \\
\hline N2 & 61825.0 & 61330.7 & -11.7 & -0.0 & 1906.8 \\
\hline $\mathrm{CH} 4$ & & 417.5 & 9.9 & 90.0 & 13.0 \\
\hline $\mathrm{co}$ & & 1931.3 & 45.8 & 46.2 & 60.0 \\
\hline NH3 & & 0.0 & 0.0 & 0.0 & 0.0 \\
\hline Total & 75600.3 & 74973.3 & 85.1 & 100.0 & \\
\hline
\end{tabular}




$\begin{array}{lrrrc} & \text { Gns In } & \text { Gns Out } & \text { rields } & \text { M Yields } \\ \text { MAF (Coal/char) } & 4223.2 & 328.0 & 7.8 & 8.3 \\ \text { H20 in coal/Char } & 2612.2 & 21.6 & -61.3 & -61.3 \\ \text { M20 in H20/Cond. } & 7349.0 & 6139.2 & -28.6 & 16.7 \\ \text { Ash } & 420.6 & 400.9 & -0.5 & 0.1 \\ \text { Sulfur } & 46.4 & 40.7 & -0.1 & 1.0\end{array}$

\begin{tabular}{|c|c|c|}
\hline Cond. Total & 0.00 & 0.00 \\
\hline ibp- 165 & 0.00 & 0.00 \\
\hline$<c 10$ & 0.00 & 0.00 \\
\hline EXT & 0.00 & 0.00 \\
\hline $165-220$ & 0.00 & 0.00 \\
\hline c10-c12 & 0.00 & 0.00 \\
\hline Phenols & 0.00 & 0.00 \\
\hline Cresols & 0.00 & 0.00 \\
\hline Maphthal. & 0.00 & 0.00 \\
\hline $220-375$ & 0.00 & 0.00 \\
\hline c13-c22 & 0.00 & 0.00 \\
\hline C2-Phenol & 0.00 & 0.00 \\
\hline Phytene & 0.00 & 0.00 \\
\hline $375-550$ & 0.00 & 0.00 \\
\hline$c 23-c 30$ & 0.00 & 0.00 \\
\hline $550-1000$ & 0.00 & 0.00 \\
\hline Aliphatics & 0.00 & 0.00 \\
\hline Phenolies & 0.00 & 0.00 \\
\hline$B P>1000$ & 0.00 & 0.00 \\
\hline Char Fines & 0.00 & 0.00 \\
\hline Residue & 0.00 & 0.00 \\
\hline
\end{tabular}

Run 1263

Center Lignite

Seam

Temp. $\quad 800 \mathrm{C}$

Pressure 100 psig

* H2O 20.3

$\% 02 \quad 2.2$

\% 2277.5

\% NO 0.0

$\%$ c02 0.0

\begin{tabular}{|c|c|c|c|c|c|}
\hline Gas Total & 61119.9 & 66486.0 & 127.1 & 136.2 & 2139.5 \\
\hline $\mathrm{H} 2$ & & 345.2 & 8.2 & 8.2 & 149.9 \\
\hline $\mathrm{CO} 2$ & & 5472.2 & 129.6 & 130.3 & 108.0 \\
\hline C3H8 & & 0.0 & 0.0 & 0.0 & 0.0 \\
\hline C3HG & & 20.6 & 0.5 & 0.5 & 0.4 \\
\hline$i-c 4$ & & 0.0 & 0.0 & 0.0 & 0.0 \\
\hline $\cos$ & & 0.0 & 0.0 & 0.0 & 0.0 \\
\hline$n-c_{4}$ & & 0.0 & 0.0 & 0.0 & 0.0 \\
\hline H2S & & 33.3 & 0.8 & 0.8 & 0.8 \\
\hline $1-B u$ & & 0.0 & 0.0 & 0.0 & 0.0 \\
\hline$t-2-8 u$ & & 0.0 & 0.0 & 0.0 & 0.0 \\
\hline$i-c 5$ & & 0.0 & 0.0 & 0.0 & 0.0 \\
\hline$c-2-B u$ & & 0.0 & 0.0 & 0.0 & 0.0 \\
\hline$n-c 5$ & & 0.0 & 0.0 & 0.0 & 0.0 \\
\hline $\mathrm{C} 2 \mathrm{H}_{4}$ & & 27.4 & 0.6 & 0.7 & 0.9 \\
\hline $\mathrm{C} 2 \mathrm{HG}$ & & 22.0 & 0.5 & 0.5 & 0.6 \\
\hline 02 & 1909.9 & 0.0 & -45.2 & -45.2 & 0.0 \\
\hline N2 & 59210.0 & 58877.1 & -7.9 & 0.2 & 1826.5 \\
\hline $\mathrm{CH}_{4}$ & & 399.5 & 9.5 & 9.5 & 12.4 \\
\hline $\mathrm{CO}$ & & 1288.7 & 30.5 & 30.7 & 40.0 \\
\hline NHS & & 0.0 & 0.0 & 0.0 & 0.0 \\
\hline Total & 75724.9 & 73375.7 & 44.4 & 100.0 & \\
\hline
\end{tabular}

Mat. Balance

96.9

$\begin{array}{lr}\text { \% loss to char1 } & 0 \\ \text { \% loss to char2 } & 2 \\ \text { \% loss to liq } & 81.5 \\ \text { \% loss to gas } & 16.5\end{array}$




\begin{tabular}{|c|c|c|c|c|c|c|c|c|}
\hline & & Gns In & Gons out & Yields & \multicolumn{2}{|l|}{ N rields } & \multirow{2}{*}{\multicolumn{2}{|c|}{$12 / 31 / 92$}} \\
\hline MAF (Coal/char) & & 4223.2 & 117.3 & 2.8 & \multicolumn{2}{|l|}{3.8} & & \\
\hline W20 in coal/Char & & 2612.2 & 9.4 & -61.6 & \multicolumn{2}{|l|}{-61.6} & & \\
\hline H2O in H2O/Cond. & & 7215.0 & 6922.6 & -6.9 & \multicolumn{2}{|l|}{53.3} & \multicolumn{2}{|l|}{ Run } \\
\hline Ash & & 420.6 & 352.5 & -1.6 & \multicolumn{2}{|l|}{-0.0} & \multicolumn{2}{|c|}{ Center Lignite } \\
\hline Sulfur & & 46.4 & 12.1 & -0.8 & \multicolumn{2}{|l|}{8.2} & \multicolumn{2}{|c|}{ Seam $45 / 417 /$ Limestone } \\
\hline & & & & & & & Temp. & $850 \mathrm{C}$ \\
\hline$-\infty-\infty+\infty, \infty-\infty, \infty+\infty)$ & & & ...... & $-\infty-\infty$ & \multirow{2}{*}{\multicolumn{2}{|c|}{0.00}} & Pressure & 100 psig \\
\hline Cond. Total & & & 0.00 & 0.00 & & & & \\
\hline ibp- 965 & & & 0.00 & 0.00 & \multicolumn{2}{|l|}{0.00} & $\%$ H2O & 21.0 \\
\hline sc10 & & & 0.00 & 0.00 & \multicolumn{2}{|l|}{0.00} & $\% 02$ & 2.3 \\
\hline BXT & & & 0.00 & 0.00 & \multicolumn{2}{|l|}{0.00} & x 12 & 76.7 \\
\hline $165-220$ & & & 0.00 & 0.00 & \multicolumn{2}{|l|}{0.00} & * NO & 0.0 \\
\hline c10-c12 & & & 0.00 & 0.00 & \multicolumn{2}{|l|}{0.00} & $\% \mathrm{CO} 2$ & 0.0 \\
\hline Phenols & & & 0.00 & 0.00 & 0.00 & & & \\
\hline Cresols & & & 0.00 & 0.00 & 0.00 & & & \\
\hline Naphthal. & & & 0.00 & 0.00 & 0.00 & & & \\
\hline $220-375$ & & & 0.00 & 0.00 & 0.00 & & & \\
\hline c13-c22 & & & 0.00 & 0.00 & 0.00 & & & \\
\hline c2-Phenol & & & 0.00 & 0.00 & 0.00 & & & \\
\hline Phytene & & & 0.00 & 0.00 & 0.00 & & & \\
\hline $375-550$ & & & 0.00 & 0.00 & 0.00 & & & \\
\hline$c 23-c 30$ & & & 0.00 & 0.00 & 0.00 & & & \\
\hline $550-1000$ & & & 0.00 & 0.00 & 0.00 & & . & \\
\hline Aliphatics & & & 0.00 & 0.00 & 0.00 & & & \\
\hline Phenolics & & & 0.00 & 0.00 & 0.00 & & & \\
\hline$B P>1000$ & & & 0.00 & 0.00 & 0.00 & & & \\
\hline Char Fines & & & 0.00 & 0.00 & 0.00 & & & \\
\hline Residue & & & 0.00 & 0.00 & 0.00 & & & \\
\hline - & $\cdots$ & $\cdots+\ldots, \ldots$ & $\ldots+\ldots, \ldots$ & $\ldots+\ldots$ & $\ldots \ldots$ & SCF & & \\
\hline Gas Total & & 57795.2 & 62098.0 & 101.9 & 104.5 & 1988.4 & & \\
\hline H2 & & & 294.6 & 7.0 & 7.0 & 127.4 & & \\
\hline $\mathrm{CO2}$ & & & 4326.9 & 102.5 & 102.6 & 85.1 & & \\
\hline C3H8 & & & 0.0 & 0.0 & 0.0 & 0.0 & & \\
\hline C3H6 & & & 0.0 & 0.0 & 0.0 & 0.0 & & \\
\hline$i-c 4$ & & & 0.0 & 0.0 & 0.0 & 0.0 & & \\
\hline $\cos$ & & & 0.0 & 0.0 & 0.0 & 0.0 & & \\
\hline$n-C_{4}$ & & & 0.0 & 0.0 & 0.0 & 0.0 & & \\
\hline H2S & & & 0.0 & 0.0 & 0.0 & 0.0 & & \\
\hline 1-Bu & & & 0.0 & 0.0 & 0.0 & 0.0 & & \\
\hline$t-2-8 u$ & & & 0.0 & 0.0 & 0.0 & 0.0 & & \\
\hline$i-c 5$ & & & 0.0 & 0.0 & 0.0 & 0.0 & & \\
\hline$c-2-B u$ & & & 0.0 & 0.0 & 0.0 & 0.0 & & \\
\hline$n-c 5$ & & & 0.0 & 0.0 & 0.0 & 0.0 & & \\
\hline $\mathrm{C} 2 \mathrm{H}_{4}$ & & & 0.0 & 0.0 & 0.0 & 0.0 & & \\
\hline $\mathrm{C2HG}$ & & & 0.0 & 0.0 & 0.0 & 0.0 & & \\
\hline 02 & & 1948.4 & 0.0 & -46.1 & -46.1 & 0.0 & & \\
\hline $\mathrm{N} 2$ & & 55846.7 & 55751.2 & -2.3 & 0.1 & 1722.6 & & \\
\hline $\mathrm{CH}_{4}$ & & & 145.7 & 3.4 & 3.5 & 4.5 & & \\
\hline $\mathrm{CO}$ & & & 1580.7 & 37.4 & 37.5 & 48.8 & & \\
\hline NH3 & & & 0.0 & 0.0 & 0.0 & 0.0 & & \\
\hline 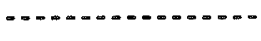 & $\cdots$ & ............... & $\ldots$ & $\cdots+\infty$ & $-\infty \cdots$ & & & \\
\hline Total & & 72266.2 & 69500.8 & 34.5 & 100.0 & & & \\
\hline Mat. Balance & & & 96.2 & & & & & \\
\hline \% loss to char 9 & 0 & & & & & & & \\
\hline$\%$ loss to char2 & 4 & & & & & & & \\
\hline$\%$ loss to liq & 92 & & & & & & & \\
\hline$\%$ loss to gas & 4 & & & & & & & \\
\hline
\end{tabular}




$\begin{array}{lrrcc} & \text { Gms In } & \text { Gns Out } & \text { Yields } & \text { Nields } \\ \text { MAF (Coal/char) } & 4334.0 & 146.4 & 3.4 & 3.4 \\ \text { H20 in coal/char } & 2612.2 & 7.6 & -60.1 & -60.1 \\ \text { H20 in M20/Cond. } & 9666.0 & 8706.2 & -22.1 & -13.3 \\ \text { Ash } & 309.8 & 305.4 & -0.1 & -0.1 \\ \text { Sulfur } & 46.4 & 34.2 & -0.3 & -0.3\end{array}$

\begin{tabular}{|c|c|c|c|}
\hline Cond. Total & 0.00 & 0.00 & 0.00 \\
\hline ibp- 165 & 0.00 & 0.00 & 0.00 \\
\hline$<610$ & 0.00 & 0.00 & 0.00 \\
\hline BXT & 0.00 & 0.00 & 0.00 \\
\hline $165-220$ & 0.00 & 0.00 & 0.00 \\
\hline c10-c12 & 0.00 & 0.00 & 0.00 \\
\hline Phenols & 0.00 & 0.00 & 0.00 \\
\hline Cresols & 0.00 & 0.00 & 0.00 \\
\hline Naphthal. & 0.00 & 0.00 & 0.00 \\
\hline $220-375$ & 0.00 & 0.00 & 0.00 \\
\hline$c 13-c 22$ & 0.00 & 0.00 & 0.00 \\
\hline c2-Phenol & 0.00 & 0.00 & 0.00 \\
\hline Phytene & 0.00 & 0.00 & 0.00 \\
\hline $375-550$ & 0.00 & 0.00 & 0.00 \\
\hline$c 23-c 30$ & 0.00 & 0.00 & 0.00 \\
\hline $550-1000$ & 0.00 & 0.00 & 0.00 \\
\hline Aliphatics & 0.00 & 0.00 & 0.00 \\
\hline Phenolics & 0.00 & 0.00 & 0.00 \\
\hline $8 P>1000$ & 0.00 & 0.00 & 0.00 \\
\hline Char Fines & 0.00 & 0.00 & 0.00 \\
\hline Residue & 0.00 & 0.00 & 0.00 \\
\hline
\end{tabular}

Run M265

Center Lignite

Seam $45 / 417$

Tenp. $850 \mathrm{C}$

Pressure 100 psig

\% $120 \quad 27.1$

$\% 02 \quad 2.2$

พ 1270.8

* NO $\quad 0.0$

* $\mathrm{CO} 20.0$

\begin{tabular}{|c|c|c|c|c|c|}
\hline Gas Total & 51687.9 & 58895.1 & 166.3 & 170.1 & 1931.2 \\
\hline $\mathrm{H} 2$ & & 443.9 & 10.2 & 10.3 & 192.2 \\
\hline $\mathrm{CO} 2$ & & 6100.6 & 140.8 & 141.2 & 120.1 \\
\hline C3H8 & & 0.0 & 0.0 & 0.0 & 0.0 \\
\hline C3H6 & & 0.0 & 0.0 & 0.0 & 0.0 \\
\hline$i-C_{4}$ & & 0.0 & 0.0 & 0.0 & 0.0 \\
\hline $\cos$ & & 0.0 & 0.0 & 0.0 & 0.0 \\
\hline$n-c 4$ & & 0.0 & 0.0 & 0.0 & 0.0 \\
\hline H2S & & 30.1 & 0.7 & 0.7 & 0.7 \\
\hline 1-Bu & & 0.0 & 0.0 & 0.0 & 0.0 \\
\hline$t-2-B u$ & & 0.0 & 0.0 & 0.0 & 0.0 \\
\hline $\mathrm{i}-\mathrm{C} 5$ & & 0.0 & 0.0 & 0.0 & 0.0 \\
\hline$c-2-B u$ & & 0.0 & 0.0 & 0.0 & 0.0 \\
\hline$n-c 5$ & & 0.0 & 0.0 & 0.0 & 0.0 \\
\hline $\mathrm{C} 2 \mathrm{H}_{4}$ & & 31.0 & 0.7 & 0.7 & 1.0 \\
\hline С2H6 & & 0.0 & 0.0 & 0.0 & 0.0 \\
\hline 02 & 1742.8 & 0.0 & -40.2 & -40.2 & 0.0 \\
\hline M2 & 49945.0 & 49823.9 & -2.8 & 0.4 & 1541.0 \\
\hline $\mathrm{CH}_{4}$ & & 425.3 & 9.8 & 9.8 & 13.2 \\
\hline co & & 2040.3 & 47.1 & 47.2 & 63.1 \\
\hline NH3 & & 0.0 & 0.0 & 0.0 & 0.0 \\
\hline Total & 68609.9 & 68060.7 & 87.3 & 100.0 & \\
\hline
\end{tabular}

Mat. Balance

99.2

$\begin{array}{lr}\text { \% loss to char1 } & 0 \\ \% \text { loss to char2 } & 0 \\ \% \text { loss to liq } & 70 \\ \% \text { loss to gas } & 30\end{array}$




\begin{tabular}{|c|c|c|c|c|c|c|c|c|}
\hline & & Gms in & Gns out & rields & \multicolumn{2}{|l|}{ Nields } & \multirow{2}{*}{\multicolumn{2}{|c|}{$12 / 31 / 92$}} \\
\hline MAF (Coal/char) & & 7501.8 & 180.0 & 2.4 & 2.4 & & & \\
\hline H2O in coal/Char & & 4788.7 & 7.3 & -63.7 & -63.7 & & \\
\hline H2O in $\mathrm{H} 20 /$ Cond. & & 0.0 & 6782.0 & 90.4 & 109.7 & & \multirow{3}{*}{\multicolumn{2}{|c|}{$\begin{array}{c}\text { Run } \quad \text { M280 } \\
\text { Center Lignite } \\
\text { Sean } \$ 5 / \text { M } 17 \text { Linestone }\end{array}$}} \\
\hline Ash & & 1011.5 & 1019.7 & 0.1 & 0.1 & & & \\
\hline \multirow[t]{3}{*}{ sulfur } & & \multirow[t]{2}{*}{78.1} & \multirow[t]{2}{*}{37.8} & \multirow[t]{2}{*}{-0.5} & \multirow[t]{2}{*}{-0.5} & & & \\
\hline & & & & & & & Temp. & $850 \mathrm{C}$ \\
\hline & & & $\cdots$ & $-\infty-\infty$ & $=--\infty-\infty$ & $---\infty-\infty-\infty$ & Pressure & 100 psig \\
\hline Cond. Total & & & 0.00 & 0.00 & 0.00 & & & \\
\hline ibp- 165 & & & 0.00 & 0.00 & 0.00 & & $\%$ *20 & 5.3 \\
\hline$<c 10$ & & & 0.00 & 0.00 & 0.00 & & $\% 02$ & 11.8 \\
\hline BXT & & & 0.00 & 0.00 & 0.00 & & $x$ ผ2 & 82.9 \\
\hline $165-220$ & & & 0.00 & 0.00 & 0.00 & & \% NO & 0.0 \\
\hline $\mathrm{c} 10-\mathrm{c} 12$ & & & 0.00 & 0.00 & 0.00 & & $x \cos$ & 0.0 \\
\hline Phenols & & & 0.00 & 0.00 & 0.00 & & & \\
\hline Cresols & & & 0.00 & 0.00 & 0.00 & & & \\
\hline Maphthal. & & & 0.00 & 0.00 & 0.00 & & & \\
\hline $220-375$ & & & 0.00 & 0.00 & 0.00 & & & \\
\hline$c 13-c 22$ & & & 0.00 & 0.00 & 0.00 & & & \\
\hline C2-Phenol & & & 0.00 & 0.00 & 0.00 & & & \\
\hline Phytene & & & 0.00 & 0.00 & 0.00 & & & \\
\hline $375-550$ & & & 0.00 & 0.00 & 0.00 & & & \\
\hline $\mathrm{c} 23-\mathrm{cs} 0$ & & & 0.00 & 0.00 & 0.00 & & & \\
\hline $550-1000$ & & & 0.00 & 0.00 & 0.00 & & & \\
\hline Aliphatics & & & 0.00 & 0.00 & 0.00 & & & \\
\hline Phenolics & & & 0.00 & 0.00 & 0.00 & & & \\
\hline$B P>1000$ & & & 0.00 & 0.00 & 0.00 & & & \\
\hline Char Fines & & & 0.00 & 0.00 & 0.00 & & & \\
\hline Residue & & & 0.00 & 0.00 & 0.00 & & & \\
\hline 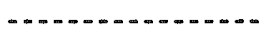 & & 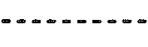 & n & 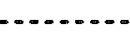 & - noson. & SCF & & \\
\hline Gas Total & & 135848.1 & 139433.6 & 47.8 & 51.5 & 3993.4 & & \\
\hline $\mathrm{H2}$ & & & 0.9 & 0.0 & 0.0 & 0.4 & & \\
\hline $\mathrm{CO} 2$ & & & 19692.4 & 262.5 & 263.0 & 387.3 & & \\
\hline C3H8 & & & 0.0 & 0.0 & 0.0 & 0.0 & & \\
\hline C3H6 & & & 59.4 & 0.8 & 0.8 & 1.2 & & \\
\hline $\mathrm{i}-\mathrm{C4}$ & & & 0.0 & 0.0 & 0.0 & 0.0 & & \\
\hline $\cos$ & & & 0.0 & 0.0 & 0.0 & 0.0 & & \\
\hline$n-C 4$ & & & 0.0 & 0.0 & 0.0 & 0.0 & & \\
\hline H2S & & & 0.0 & 0.0 & 0.0 & 0.0 & & \\
\hline $9-B u$ & & & 0.0 & 0.0 & 0.0 & 0.0 & & \\
\hline$t-2-B u$ & & & 0.0 & 0.0 & 0.0 & 0.0 & & \\
\hline$i-c 5$ & & & 0.0 & 0.0 & 0.0 & 0.0 & & \\
\hline$c-2-8 u$ & & & 0.0 & 0.0 & 0.0 & 0.0 & & \\
\hline$n-c 5$ & & & 0.0 & 0.0 & 0.0 & 0.0 & & \\
\hline $\mathrm{C} 2 \mathrm{H}_{4}$ & & & 13.2 & 0.2 & 0.2 & 0.4 & & \\
\hline с2H6 & & & 0.0 & 0.0 & 0.0 & 0.0 & & \\
\hline 02 & & 19001.5 & 3045.3 & -212.7 & -212.6 & 0.0 & & \\
\hline N2 & & 116846.6 & 116622.4 & -3.0 & 0.1 & 3604.1 & & \\
\hline $\mathrm{CH} 4$ & & & 0.0 & 0.0 & 0.0 & 0.0 & & \\
\hline $\mathrm{CO}$ & & & 0.0 & 0.0 & 0.0 & 0.0 & & \\
\hline MH3 & & & 0.0 & 0.0 & 0.0 & 0.0 & & \\
\hline Total & & 949150.2 & 147422.6 & 77.0 & 100.0 & & & \\
\hline Mat. Balance & & & 98.8 & & & & & \\
\hline$\%$ loss to char 1 & 0 & & & & & & & \\
\hline \% loss to char2 & 0 & & & & & & & \\
\hline$\%$ loss to liq & 84 & & & & & & & \\
\hline$\%$ loss to gas & 16 & & & & & & & \\
\hline
\end{tabular}




\begin{tabular}{|c|c|c|c|c|c|c|c|c|}
\hline & & Gns In & Gns Out & Yields & \multicolumn{2}{|l|}{ Mields } & \multirow{2}{*}{\multicolumn{2}{|c|}{$12 / 31 / 92$}} \\
\hline MAF (Coal/char) & & 5944.2 & 177.3 & 3.0 & \multicolumn{2}{|l|}{4.6} & & \\
\hline H2O in coal/char & & 3918.2 & 91.5 & -65.7 & \multicolumn{2}{|l|}{-65.7} & & \\
\hline $\mathrm{H} 20$ in $\mathrm{H} 20 /$ Cond. & & 8494.5 & 7759.0 & -12.4 & \multicolumn{2}{|l|}{-8.1} & \multicolumn{2}{|c|}{ M281 } \\
\hline Ash & & 1021.6 & 704.6 & -5.3 & \multicolumn{2}{|l|}{0.1} & \multicolumn{2}{|c|}{ Center Lignite } \\
\hline \multirow[t]{2}{*}{ sulfur } & & \multirow[t]{2}{*}{64.2} & \multirow[t]{2}{*}{45.6} & \multirow[t]{2}{*}{-0.3} & \multirow[t]{2}{*}{0.0} & & \multicolumn{2}{|c|}{ Seam H5/417/0olomite } \\
\hline & & & & & & & Temp. & $850 \mathrm{C}$ \\
\hline nand & $\cdots$ & $\infty-\infty-\infty$ & $\infty \ldots+\infty$ & $\infty-\infty$ & $-\infty-\infty-\infty-\infty$ & $-000-00000$ & Pressure & 100 psig \\
\hline Cond. Total & & & 0.00 & 0.00 & 0.00 & & & \\
\hline ibp- 165 & & & 0.00 & 0.00 & 0.00 & & $\%$ H2O & 18.8 \\
\hline$<\mathrm{C} 10$ & & & 0.00 & 0.00 & 0.00 & & \% 02 & 2.5 \\
\hline BXT & & & 0.00 & 0.00 & 0.00 & & * N2 & 78.7 \\
\hline $165-220$ & & & 0.00 & 0.00 & 0.00 & & * NO & 0.0 \\
\hline c10-c12 & & & 0.00 & 0.00 & 0.00 & & \& $\mathrm{CO} 2$ & 0.0 \\
\hline Phenols & & & 0.00 & 0.00 & 0.00 & & & \\
\hline Cresols & & & 0.00 & 0.00 & 0.00 & & & \\
\hline Maphthal. & & & 0.00 & 0.00 & 0.00 & & & \\
\hline $220-375$ & & & 0.00 & 0.00 & 0.00 & & & \\
\hline$c 13-c 22$ & & & 0.00 & 0.00 & 0.00 & & & \\
\hline c2-Phenol & & & 0.00 & 0.00 & 0.00 & & & \\
\hline Phytene & & & 0.00 & 0.00 & 0.00 & & & \\
\hline $375-550$ & & & 0.00 & 0.00 & 0.00 & & & \\
\hline$c 23-c 30$ & & & 0.00 & 0.00 & 0.00 & & & \\
\hline $550-1000$ & & & 0.00 & 0.00 & 0.00 & & . & \\
\hline Aliphatics & & & 0.00 & 0.00 & 0.00 & & & \\
\hline Phenolics & & & 0.00 & 0.00 & 0.00 & & & \\
\hline$B P>1000$ & & & 0.00 & 0.00 & 0.00 & & & \\
\hline Char Fines & & & 0.00 & 0.00 & 0.00 & & & \\
\hline Residue & & & 0.00 & 0.00 & 0.00 & & & \\
\hline 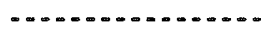 & $\cdots$ & $\ldots-\infty-\infty, \ldots$ & n & $\infty-\infty \ldots \infty$ & $-\infty-\infty$ & scF & & \\
\hline Gas Total & & 83829.7 & 93712.6 & 166.3 & 169.1 & 3035.1 & & \\
\hline $\mathrm{H2}$ & & & 588.3 & 9.8 & 9.9 & 254.5 & & \\
\hline $\mathrm{CO} 2$ & & & 8556.5 & 143.9 & 144.2 & 168.2 & & \\
\hline СЗн8 & & & 0.0 & 0.0 & 0.0 & 0.0 & & \\
\hline C3H6 & & & 44.4 & 0.7 & 0.7 & 0.9 & & \\
\hline$i-C_{4}$ & & & 0.0 & 0.0 & 0.0 & 0.0 & & \\
\hline $\cos$ & & & 0.0 & 0.0 & 0.0 & 0.0 & & \\
\hline$n-c 4$ & & & 0.0 & 0.0 & 0.0 & 0.0 & & \\
\hline H2S & & & 24.0 & 0.4 & 0.4 & 0.5 & & \\
\hline $1-8 u$ & & & 0.0 & 0.0 & 0.0 & 0.0 & & \\
\hline$t-2-8 u$ & & & 0.0 & 0.0 & 0.0 & 0.0 & & \\
\hline$i-c 5$ & & & 0.0 & 0.0 & 0.0 & 0.0 & & \\
\hline$c-2-B u$ & & & 0.0 & 0.0 & 0.0 & 0.0 & & \\
\hline$n-65$ & & & 0.0 & 0.0 & 0.0 & 0.0 & & \\
\hline $\mathrm{C} 2 \mathrm{H}_{4}$ & & & 49.3 & 0.8 & 0.8 & 1.5 & & \\
\hline С2н6 & & & 0.0 & 0.0 & 0.0 & 0.0 & & \\
\hline 02 & & 2924.6 & 0.0 & -49.2 & -49.2 & 0.0 & & \\
\hline N2 & & 80905.1 & 80797.5 & -1.8 & 0.6 & 2496.5 & & \\
\hline CH4 & & & 488.0 & 8.3 & 8.4 & 15.3 & & \\
\hline co & & & 3956.5 & 53.1 & 53.2 & 97.5 & & \\
\hline NH3 & & & 0.0 & 0.0 & 0.0 & 0.0 & & \\
\hline Total & & 103208.2 & 102365.0 & 85.8 & 100.0 & & & \\
\hline Mat. Balance & & & 99.2 & & & & & \\
\hline$\%$ loss to char 1 & 0 & & & & & & & \\
\hline \% loss to char2 & 50 & & & & & & & \\
\hline \% loss to liq & 30 & & & & & & & \\
\hline$\%$ loss to gas & 20 & & & & & & & \\
\hline
\end{tabular}




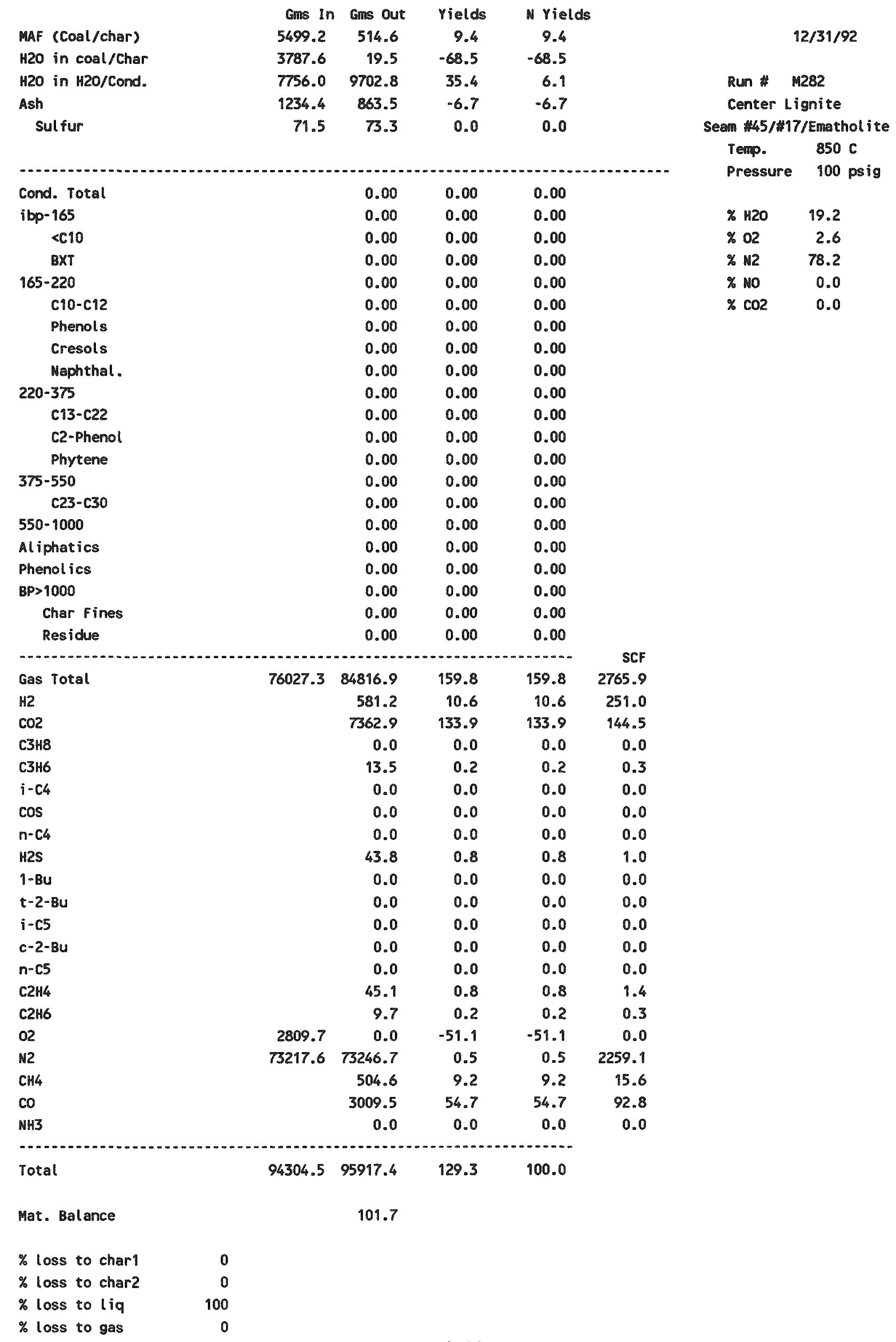




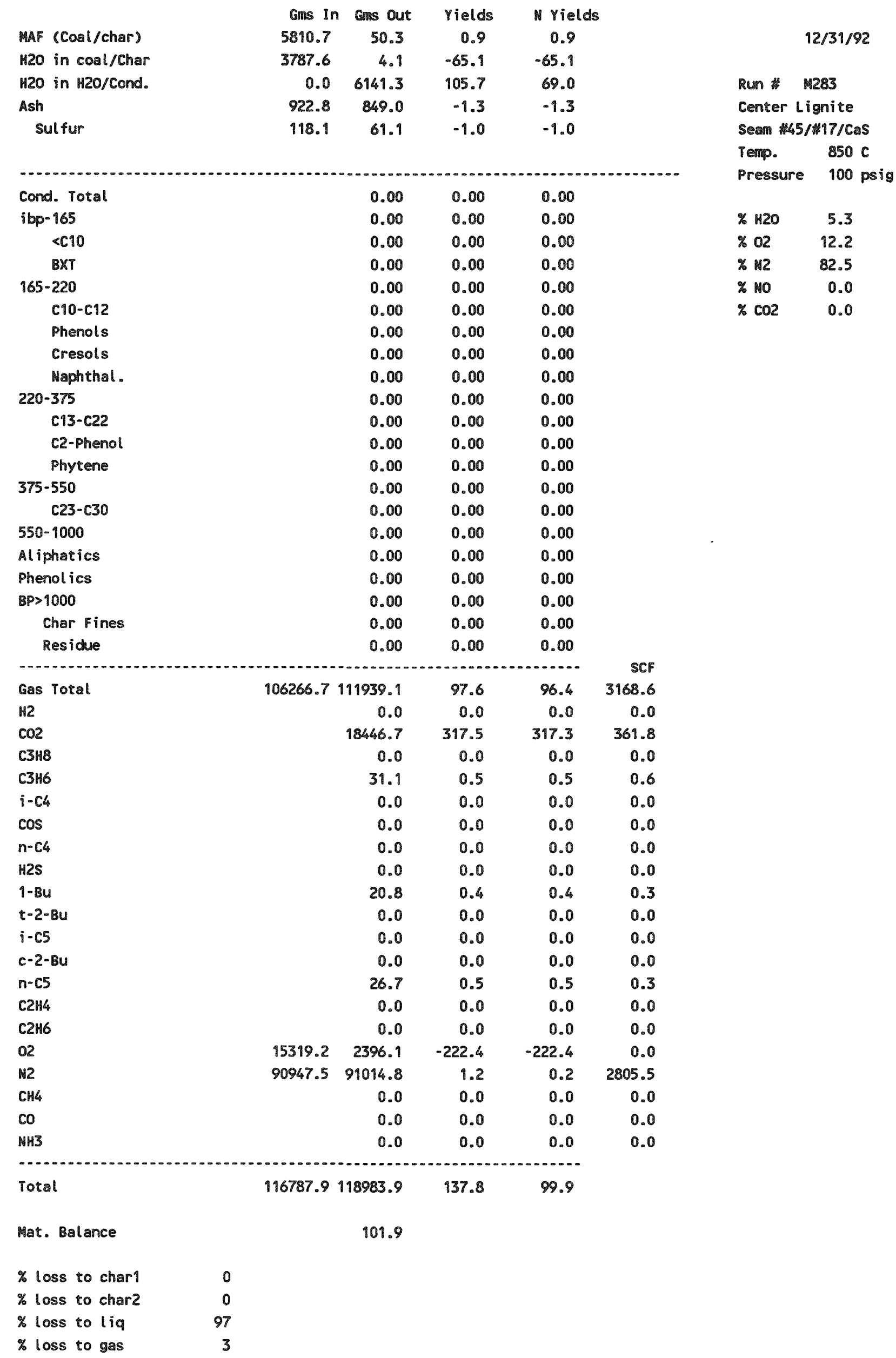


APPENDIX B

SEMPC AND XRD DATA 
UND-EERC SEMPC Mineral Classification Ver. 3.1, Run Date: Dec 171992 Using definitions file rules.c

M261 Bed Material, Hi-Na $800^{\circ} \mathrm{C}$ Gasification - 4946

\begin{tabular}{|c|c|c|c|}
\hline Mineral & Frequency, \% & Mineral & Frequency, \% \\
\hline Oxide-Rich & & Silicon-Rich & \\
\hline Magnesium Oxide & 0.0 & Quartz & 0.0 \\
\hline Aluminum Oxide & 0.0 & Albite & 0.0 \\
\hline Calcium Oxide & 2.5 & Anorthite & 0.0 \\
\hline Titanium Oxide & 0.0 & Potassium Feldspar & 0.0 \\
\hline Chromium Oxide & 0.0 & Nepheline & 0.0 \\
\hline Iron Oxide & 0.3 & Haüyne & 0.0 \\
\hline Spinel & 0.0 & Leucite & 0.0 \\
\hline $\mathrm{Ca} \mathrm{Ti}$ Oxide & 0.0 & Kaolinite & $\mathbf{3 . 4}$ \\
\hline Ca Al Oxide & 0.0 & Altered Kaolinite & 0.0 \\
\hline Mixed-Oxide-Rich & 0.6 & Illite & 0.0 \\
\hline \multirow[t]{2}{*}{ Total for Group } & 3.4 & Montmorillonite & 0.0 \\
\hline & & Pyrozene & 0.0 \\
\hline Sulfur-Rich & & Wollastonite & 0.0 \\
\hline Pyrite & 6.9 & Ca Silicate & 0.0 \\
\hline Pyrrhotite & 2.8 & Dicalcium Silicate & 0.0 \\
\hline Iron Sulfate & 0.6 & $\mathrm{NaCaSiO}_{3}$ & 0.3 \\
\hline Sodium Sulfate & 0.0 & Gehlenite & 0.0 \\
\hline Calcium Sulfate & 0.9 & Akermanite & 0.0 \\
\hline $\mathrm{Na} \mathrm{Ca}$ Sulfate & 0.3 & Merwinite & 0.0 \\
\hline Barite & 0.0 & Spurrite & 0.0 \\
\hline Mixed-Sulfur-Rich & 8.4 & Mullite & 0.0 \\
\hline \multirow[t]{2}{*}{ Total for Group } & 20.0 & Mized-Silicon-Rich & 0.9 \\
\hline & & Total for Group & 4.7 \\
\hline \multicolumn{4}{|l|}{ Phosphorous-Rich } \\
\hline Apatite & 0.0 & & \\
\hline Mixed-Phosphorous-Rich & 1.2 & User-Defined-List & \\
\hline \multirow[t]{2}{*}{ Total for Group } & 1.2 & Ettringite & 0.0 \\
\hline & & Calcium Aluminate & 0.0 \\
\hline Carbon-Rich & & Total for Group & 0.0 \\
\hline Calcite & 34,1 & & \\
\hline Altered Calcite & 18.1 & & \\
\hline Dolomite & 0.6 & & \\
\hline Sulfated Dolomite & 0.0 & OTHER & 2.2 \\
\hline Ankerite & 0.0 & & \\
\hline Sulfated Ankerite & 0.0 & & \\
\hline Mixed-Carbon-Rich & 12.2 & & \\
\hline Total for Group & 65.0 & & \\
\hline \multicolumn{4}{|l|}{ Metal-Rich } \\
\hline Aluminum & 0.0 & & \\
\hline Titanium & 0.0 & & \\
\hline Iron & 0.0 & & \\
\hline Nickel & 0.0 & & \\
\hline Copper & 0.0 & & \\
\hline Chromium & 0.0 & & \\
\hline Mixed-Metal-Rich & 3.4 & & \\
\hline Total for Group & 3.4 & & \\
\hline \multicolumn{3}{|c|}{ TOTAL NUMBER OF POINTS ANALYZED } & 320 \\
\hline \multicolumn{3}{|c|}{ Carbon Threshhold for Analysis } & 250 \\
\hline \multicolumn{3}{|c|}{ Oxygen Threshhold for Analysis } & 100 \\
\hline
\end{tabular}


UND-EERC SEMPC Mineral Classification Ver. 3.1, Run Date: Dec 171992 4946 BULK CHEMICAL COMPOSITION

\begin{tabular}{lrrrrrrrrr}
\hline & \multicolumn{1}{c}{$\mathrm{A}$} & \multicolumn{1}{c}{$\mathrm{B}$} & \multicolumn{1}{c}{$\mathrm{C}$} & \multicolumn{1}{c}{$\mathrm{D}$} & $\mathrm{E}$ & $\mathrm{F}$ & $\mathrm{G}$ & $\mathrm{H}$ & $\mathrm{I}$ \\
\hline $\mathrm{SiO}_{2}$ & 2.6 & 1.5 & 4.9 & 5.6 & 32.7 & 2.4 & 26.8 & 7.8 & 8.5 \\
$\mathrm{Al}_{2} \mathrm{O}_{3}$ & 22.9 & 20.8 & 3.9 & 2.3 & 18.5 & 1.1 & 2.5 & 5.3 & 5.6 \\
$\mathrm{Fe}_{2} \mathrm{O}_{3}$ & 19.6 & 5.7 & 1.9 & 9.9 & 35.5 & 0.2 & 2.0 & 11.8 & 15.7 \\
$\mathrm{TiO}_{2}$ & 0.2 & 0.0 & 0.1 & 0.7 & 0.0 & 0.1 & 0.0 & 0.1 & 0.1 \\
$\mathrm{P}_{2} \mathrm{O}_{5}$ & 0.0 & 0.0 & 1.0 & 43.1 & 0.1 & 0.2 & 0.0 & 0.8 & 0.9 \\
$\mathrm{CaO} \mathrm{O}$ & 44.8 & 41.6 & 42.8 & 23.9 & 1.5 & 90.3 & 54.8 & 61.0 & 64.4 \\
$\mathrm{MgO}$ & 5.1 & 24.6 & 5.9 & 0.7 & 0.6 & 0.7 & 2.0 & 1.7 & 2.1 \\
$\mathrm{Na}_{2} \mathrm{O}$ & 3.4 & 5.5 & 6.4 & 6.9 & 3.7 & 1.1 & 10.0 & 1.9 & 2.6 \\
$\mathrm{~K}_{2} \mathrm{O}$ & 0.1 & 0.0 & 0.5 & 0.2 & 0.1 & 0.2 & 0.1 & 0.1 & 0.2 \\
$\mathrm{SO}_{3}$ & 1.1 & 0.2 & 31.6 & 6.2 & 2.9 & 2.6 & 1.5 & 8.4 & 0.0 \\
$\mathrm{Cl}_{2} \mathrm{O}_{7}$ & 0.2 & 0.2 & 0.8 & 0.4 & 4.4 & 0.5 & 0.1 & 0.9 & 0.0 \\
$\mathrm{Cr}_{2} \mathrm{O}_{3}$ & 0.1 & 0.0 & 0.1 & 0.1 & 0.0 & 0.1 & 0.0 & 0.1 & 0.0 \\
$\mathrm{BaO} \mathrm{O}$ & 0.0 & 0.0 & 0.1 & 0.1 & 0.0 & 0.4 & 0.1 & 0.1 & 0.0 \\
\hline $\mathrm{A}$
\end{tabular}
A. Cumulative bulk composition of OTHER.
B. Cumulative bulk composition of mixed-oxide-rich.
C. Cumulative bulk composition of mixed-sulfur-rich.
D. Cumulative bulk composition of mixed-phosphorous-rich.
E. Cumulative bulk composition of mixed-carbon-rich.
F. Cumulative bulk composition of mixed-metal-rich.
G. Cumulative bulk composition of mixed-silicon-rich.
H. Cumulative bulk composition of the entire sample.
I. $\mathrm{SO}_{3^{-}}, \mathrm{Cl}_{2} \mathrm{O}_{7^{-}}, \mathrm{Cr}_{2} \mathrm{O}_{3^{-}}, \mathrm{BaO}$-free composition of the entire sample. 
UND-EERC SEMPC Mineral Classification Ver. 3.1, Run Date: Dec 171992

Using definitions file rules.c M262 Bed Material, $\mathrm{Hi}-\mathrm{Na} 850^{\circ} \mathrm{C}$ Gasification - 4947

\begin{tabular}{|c|c|c|c|}
\hline Mineral Name & Frequency, \% & Mineral Name & Frequency, \% \\
\hline Oxide-Rich & & Silicon-Rich & \\
\hline Magnesium Oxide & 0.0 & Quartz & 0.0 \\
\hline Aluminum Oxide & 0.0 & Albite & 0.0 \\
\hline Calcium Oxide & 0.4 & Anorthite & 0.0 \\
\hline Titanium Oxide & 0.0 & Potassium Feldspar & 0.0 \\
\hline Chromium Oxide & 0.0 & Nepheline & 0.0 \\
\hline Iron Oxide & 0.0 & Haüyne & 0.0 \\
\hline Spinel & 0.0 & Leucite & 0.0 \\
\hline $\mathrm{Ca} \mathrm{Ti}$ Oxide & 0.0 & Kaolinite & 0.0 \\
\hline Ca Al Oxide & 0.0 & Altered Kaolinite & 0.0 \\
\hline Mixed-Oxide-Rich & 0.0 & Illite & 0.0 \\
\hline \multirow[t]{2}{*}{ Total for Group } & 0.4 & Montmorillonite & 0.0 \\
\hline & & Pyroxene & 0.0 \\
\hline Sulfur-Rich & & Wollastonite & 0.0 \\
\hline Pyrite & 0.0 & Ca Silicate & 0.0 \\
\hline Pyrrhotite & 0.0 & Dicalcium Silicate & 0.0 \\
\hline Iron Sulfate & 0.0 & $\mathrm{NaCaSiO}_{3}$ & 0.0 \\
\hline Sodium Sulfate & 0.0 & Gehlenite & 0.0 \\
\hline Calcium Sulfate & 2.4 & Akermanite & 0.0 \\
\hline $\mathrm{Na} \mathrm{Ca}$ Sulfate & 1.2 & Merwinite & 0.0 \\
\hline Barite & 0.0 & Spurrite & 0.0 \\
\hline Mixed-Sulfur-Rich & 6.8 & Mullite & 0.0 \\
\hline \multirow[t]{2}{*}{ Total for Group } & 10.4 & Mixed-Silicon-Rich & 0.0 \\
\hline & & Total for Group & 0.0 \\
\hline \multicolumn{4}{|l|}{ Phosphorous-Rich } \\
\hline Apatite & & & 0.0 \\
\hline Mixed-Phosphorous-Rich & 0.4 & User-Defined-List & \\
\hline \multirow[t]{2}{*}{ Total for group } & 0.4 & Ettringite & 0.0 \\
\hline & & Calcium Aluminate & 0.0 \\
\hline Carbon-Rich & & Total for Group & 0.0 \\
\hline Calcite & & & 49.8 \\
\hline Altered Calcite & & & 16.1 \\
\hline Dolomite & & & 0.4 \\
\hline Sulfated Dolomite & 0.0 & OTHER & 0.0 \\
\hline Ankerite & & & 0.0 \\
\hline Sulfated Ankerite & & & 0.0 \\
\hline Mixed-Carbon-Rich & & & 22.5 \\
\hline Total for Group & & & 88.8 \\
\hline \multicolumn{4}{|l|}{ Metal-Rich } \\
\hline Aluminum & & & 0.0 \\
\hline Titanium & & & 0.0 \\
\hline Iron & & & 0.0 \\
\hline Nickel & & & 0.0 \\
\hline Copper & & & 0.0 \\
\hline Chromium & & & 0.0 \\
\hline Mixed-Metal-Rich & & & 0.0 \\
\hline \multirow[t]{2}{*}{ Total for Group } & & & 0.0 \\
\hline & & & 249 \\
\hline \multicolumn{4}{|c|}{ TOTAL NUMBER OF POINTS ANALYZED } \\
\hline Carbon Threshhold for Analysis & & & 250 \\
\hline Oxygen Threshhold for Analysis & & & 100 \\
\hline
\end{tabular}


UND-EERC SEMPC Mineral Classification Ver. 3.1, Run Date: Dec 171992 4947

BULK CHEMICAL COMPOSITION

\begin{tabular}{lrrrrr}
\hline & $\mathrm{A}$ & $\mathrm{B}$ & $\mathrm{C}$ & $\mathrm{D}$ & $\mathrm{E}$ \\
\hline $\mathrm{SiO}_{2}$ & 6.1 & 0.9 & 10.8 & 4.4 & 8.1 \\
$\mathrm{Al}_{2} \mathrm{O}_{3}$ & 3.4 & 37.5 & 4.4 & 1.8 & 2.5 \\
$\mathrm{Fe}_{2} \mathrm{O}_{3}$ & 1.2 & 1.2 & 27.1 & 6.5 & 7.5 \\
$\mathrm{TiO}_{2}$ & 0.1 & 0.0 & 0.0 & 0.1 & 0.3 \\
$\mathrm{P}_{2} \mathrm{O}_{5}$ & 0.2 & 21.0 & 0.1 & 0.3 & 0.6 \\
$\mathrm{CaO}$ & 46.0 & 12.3 & 2.4 & 66.8 & 75.2 \\
$\mathrm{MgO}$ & 3.2 & 1.3 & 0.3 & 1.3 & 1.8 \\
$\mathrm{Na}_{2} \mathrm{O}$ & 4.3 & 21.5 & 1.4 & 1.2 & 3.3 \\
$\mathrm{~K}_{2} \mathrm{O}$ & 0.2 & 0.0 & 0.5 & 0.2 & 0.7 \\
$\mathrm{SO}_{3}$ & 31.5 & 2.0 & 5.4 & 5.9 & 0.0 \\
$\mathrm{Cl}_{2} \mathrm{O}_{7}$ & 3.6 & 1.4 & 47.4 & 11.6 & 0.0 \\
$\mathrm{Cr}_{2} \mathrm{O}_{3}$ & 0.2 & 0.0 & 0.1 & 0.1 & 0.0 \\
$\mathrm{BaO}$ & 0.0 & 0.9 & 0.0 & 0.0 & 0.0 \\
\hline
\end{tabular}
A. Cumulative bulk composition of mixed-sulfur-rich.
B. Cumulative bulk composition of mixed-phosphorous-rich.
C. Cumulative bulk composition of mixed-carbon-rich.
D. Cumulative bulk composition of the entire sample.
E. $\mathrm{SO}_{3^{-}}, \mathrm{Cl}_{2} \mathrm{O}_{7^{-}}, \mathrm{Cr}_{2} \mathrm{O}_{9^{-}}, \mathrm{BaO}$-free composition of the entire sample. 
UND-EERC SEMPC Mineral Classification Ver. 3.1, Run Date: Dec 171992

Using definitions file rules.c

M262 Wall Deposits, Hi-Na $850^{\circ} \mathrm{C}$ Gasification - 4948

\begin{tabular}{|c|c|c|c|}
\hline Mineral Name & Frequency, \% & Mineral Name & Frequency, $\%$ \\
\hline Oxide-Rich & & Silicon-Rich & \\
\hline Magnesium Oxide & 0.3 & Quartz & 0.0 \\
\hline Aluminum Oxide & 0.0 & Albite & 0.0 \\
\hline Calcium Oxide & 0.6 & Anorthite & 0.0 \\
\hline Titanium Oxide & 0.0 & Potassium Feldspar & 0.0 \\
\hline Chromium Oxide & 0.0 & Nepheline & 0.0 \\
\hline Iron Oxide & 0.0 & Haüyne & 0.0 \\
\hline Spinel & 0.0 & Leucite & 0.0 \\
\hline Ca Ti Oxide & 0.0 & Kaolinite & 0.3 \\
\hline $\mathrm{Ca}$ Al Oxide & 0.0 & Altered Kaolinite & 0.0 \\
\hline Mixed-Oxide-Rich & 1.2 & Illite & 0.0 \\
\hline \multirow[t]{2}{*}{ Total for Group } & 2.1 & Montmorillonite & 0.0 \\
\hline & & Pyroxene & 0.0 \\
\hline Sulfur-Rich & & Wollastonite & 0.0 \\
\hline Pyrite & 0.0 & Ca Silicate & 4.2 \\
\hline Pyrrhotite & 0.0 & Dicalcium Silicate & 0.0 \\
\hline Iron Sulfate & 0.0 & $\mathrm{NaCaSiO}_{3}$ & 0.3 \\
\hline Sodium Sulfate & 0.0 & Gehlenite & 0.6 \\
\hline Calcium Sulfate & 0.9 & Akermanite & 0.0 \\
\hline $\mathrm{Na} \mathrm{Ca}$ Sulfate & 3.0 & Merwinite & 0.0 \\
\hline Barite & 0.0 & Spurrite & 0.0 \\
\hline Mixed-Sulfur-Rich & 22.8 & Mullite & 0.0 \\
\hline \multirow[t]{2}{*}{ Total for Group } & 26.7 & Mixed-Silicon-Rich & 15.3 \\
\hline & & Total for Group & 20.7 \\
\hline \multicolumn{4}{|l|}{ Phosphorous-Rich } \\
\hline Apatite & & & 0.0 \\
\hline Mixed-Phosphorous-Rich & 0.3 & User-Defined-List & \\
\hline \multirow{2}{*}{ Total for Group } & 0.3 & Ettringite & 0.0 \\
\hline & & Calcium Aluminate & 0.0 \\
\hline Carbon-Rich & & Total for Group & 0.0 \\
\hline Calcite & & & 27.0 \\
\hline Altered Calcite & & & 0.3 \\
\hline Dolomite & & & 0.0 \\
\hline Sulfated Dolomite & 0.0 & OTHER & 8.1 \\
\hline Ankerite & & & 0.0 \\
\hline Sulfated Ankerite & & & 0.0 \\
\hline Mixed-Carbon-Rich & & & 14.4 \\
\hline Total for Group & & & 41.7 \\
\hline \multicolumn{4}{|l|}{ Metal-Rich } \\
\hline Aluminum & & & 0.0 \\
\hline Titanium & & & 0.0 \\
\hline Iron & & & 0.0 \\
\hline Nickel & & & 0.0 \\
\hline Copper & & & 0.0 \\
\hline Chromium & & & 0.0 \\
\hline Mixed-Metal-Rich & & & 0.3 \\
\hline \multirow[t]{2}{*}{ Total for Group } & & & 0.3 \\
\hline & & & 333 \\
\hline \multicolumn{4}{|c|}{ TOTAL NUMBER OF POINTS ANALYZED } \\
\hline \multirow{2}{*}{\multicolumn{3}{|c|}{ Carbon Threshhold for Analysis }} & 250 \\
\hline & \multicolumn{2}{|c|}{ Oxygen Threshhold for Analysis } & 100 \\
\hline
\end{tabular}


UND-EERC SEMPC Mineral Classification Ver. 3.1, Run Date: Dec 171992

\begin{tabular}{lrrrrrrrrr}
\hline & $\mathrm{A}$ & $\mathrm{B}$ & $\mathrm{C}$ & $\mathrm{D}$ & $\mathrm{E}$ & $\mathrm{F}$ & $\mathrm{G}$ & $\mathrm{H}$ & $\mathrm{I}$ \\
\hline $\mathrm{SiO}_{2}$ & 4.6 & 3.4 & 4.7 & 3.5 & 11.1 & 7.4 & 23.9 & 12.7 & 13.9 \\
$\mathrm{Al}_{2} \mathrm{O}_{3}$ & 22.8 & 34.4 & 2.8 & 20.4 & 17.7 & 0.8 & 7.5 & 9.6 & 10.3 \\
$\mathrm{Fe}_{2} \mathrm{O}_{3}$ & 8.5 & 0.6 & 2.3 & 0.0 & 4.6 & 2.5 & 1.5 & 3.4 & 4.0 \\
$\mathrm{TiO}_{2}$ & 0.3 & 0.0 & 0.1 & 0.0 & 0.2 & 0.5 & 0.1 & 0.2 & 0.2 \\
$\mathrm{P}_{2} \mathrm{O}_{5}$ & 0.4 & 0.3 & 0.2 & 19.4 & 0.4 & 0.3 & 0.7 & 0.5 & 0.5 \\
$\mathrm{CaO}$ & 33.1 & 45.1 & 31.6 & 30.6 & 20.6 & 73.4 & 38.5 & 36.5 & 47.3 \\
$\mathrm{MgO}_{\mathrm{NaO}}$ & 12.6 & 1.0 & 4.6 & 1.4 & 15.1 & 0.5 & 2.0 & 5.9 & 6.8 \\
$\mathrm{Na}_{2} \mathrm{O}$ & 13.2 & 11.0 & 9.7 & 20.3 & 19.5 & 4.1 & 20.5 & 14.6 & 16.6 \\
$\mathrm{~K}_{2} \mathrm{O}$ & 0.2 & 0.1 & 0.1 & 0.0 & 0.2 & 0.3 & 0.2 & 0.2 & 0.2 \\
$\mathrm{SO}_{3}$ & 3.8 & 3.9 & 43.1 & 3.8 & 6.4 & 8.3 & 4.6 & 15.1 & 0.0 \\
$\mathrm{Cl}_{2} \mathrm{O}_{7}$ & 0.2 & 0.0 & 0.5 & 0.0 & 2.9 & 1.9 & 0.1 & 1.0 & 0.0 \\
$\mathrm{Cr}_{2} \mathrm{O}_{3}$ & 0.0 & 0.0 & 0.1 & 0.0 & 1.2 & 0.0 & 0.0 & 0.2 & 0.0 \\
$\mathrm{BaO}$ & 0.1 & 0.1 & 0.2 & 0.6 & 0.1 & 0.0 & 0.2 & 0.2 & 0.0 \\
\hline
\end{tabular}
A. Cumulative bulk composition of OTHER.
B. Cunaulative bulk composition of mixed-oxide-rich.
C. Cumulative bulk composition of mixed-sulfur-rich.
D. Cumulative bulk composition of mixed-phosphorous-rich.
E. Cumulative bulk composition of mixed-carbon-rich.
F. Cumulative bulk composition of mixed-metal-rich.
G. Cumulative bulk composition of mixed-silicon-rich.
$\mathrm{H}$. Cumulative bulk composition of the entire sample.
I. $\mathrm{SO}_{3^{-}}, \mathrm{Cl}_{2} \mathrm{O}_{7^{-}}, \mathrm{Cr}_{2} \mathrm{O}_{3^{-}}, \mathrm{BaO}$-free composition of the entire sample. 
UND-EERC SEMPC Mineral Classification Ver. 3.1, Run Date: Dec 171992

Using definitions file rules.c

Unreacted Limestone - 4949

\begin{tabular}{|c|c|c|c|}
\hline Mineral Name & Frequency, \% & Mineral Name & Frequency, $\%$ \\
\hline Oxide-Rich & & Silicon-Rich & \\
\hline Magnesium Oxide & 0.0 & Quartz & 0.0 \\
\hline Aluminum Oxide & 0.0 & Albite & 0.0 \\
\hline Calcium Oxide & 0.0 & Anorthite & 0.0 \\
\hline Titanium Oxide & 0.0 & Potassium Feldspar & 0.0 \\
\hline Chromium Oxide & 0.0 & Nepheline & 0.0 \\
\hline Iron Oxide & 0.0 & Haüyne & 0.0 \\
\hline Spinel & 0.0 & Leucite & 0.0 \\
\hline Ca Ti Oxide & 0.0 & Kaolinite & 0.0 \\
\hline Ca Al Oxide & 0.0 & Altered Kaolinite & 0.0 \\
\hline Mixed-Oxide-Rich & 0.0 & nlite & 0.0 \\
\hline \multirow[t]{2}{*}{ Total for Group } & 0.0 & Montmorillonite & 0.0 \\
\hline & & Pyroxene & 0.0 \\
\hline Sulfur-Rich & & Wollastonite & 0.0 \\
\hline Pyrite & 0.0 & Ca Silicate & 0.0 \\
\hline Pyrrhotite & 0.0 & Dicalcium Silicate & 0.0 \\
\hline Iron Sulfate & 0.8 & $\mathrm{NaCaSiO}_{3}$ & 0.0 \\
\hline Sodium Sulfate & 0.0 & Gehlenite & 0.0 \\
\hline Calcium Sulfate & 0.0 & Akermanite & 0.0 \\
\hline $\mathrm{Na}$ Ca Sulfate & 0.0 & Merwinite & 0.0 \\
\hline Barite & 0.0 & Spurrite & 0.0 \\
\hline Mixed-Sulfur-Rich & 0.0 & Mullite & 0.0 \\
\hline \multirow[t]{2}{*}{ Total for Group } & 0.8 & Mixed-Silicon-Rich & 3.2 \\
\hline & & Total for Group & 3.2 \\
\hline \multicolumn{4}{|l|}{ Phosphorous-Rich } \\
\hline Apatite & & & 0.0 \\
\hline Mixed-Phosphorous-Rich & 0.0 & User-Defined-List & \\
\hline \multirow{2}{*}{ Total for Group } & 0.0 & Ettringite & 0.0 \\
\hline & & Calcium Aluminate & 0.0 \\
\hline Carbon-Rich & & Total for Group & 0.0 \\
\hline Calcite & 0.0 & & \\
\hline Altered Calcite & 0.0 & & \\
\hline Dolomite & 0.0 & & \\
\hline Sulfated Dolomite & 0.0 & OTHER & 0.8 \\
\hline Ankerite & 0.0 & & \\
\hline Sulfated Ankerite & 0.0 & & \\
\hline Mixed-Carbon-Rich & 0.0 & & \\
\hline Total for Group & 0.0 & & \\
\hline \multicolumn{4}{|l|}{ Metal-Rich } \\
\hline Aluminum & 0.0 & & \\
\hline Titanium & 0.0 & & \\
\hline Iron & 0.0 & & \\
\hline Nickel & 0.0 & & \\
\hline Copper & 0.0 & & \\
\hline Chromium & 0.0 & & \\
\hline Mixed-Metal-Rich & 95.2 & & \\
\hline \multirow[t]{2}{*}{ Total for Group } & 95.2 & & \\
\hline & & & 125 \\
\hline \multicolumn{4}{|c|}{ TOTAL NUMBER OF POINTS ANALYZED } \\
\hline \multicolumn{3}{|c|}{ Carbon Threshhold for Analysis } & 250 \\
\hline \multicolumn{2}{|l|}{ Oxygen Threshhold for Analysis } & & 100 \\
\hline
\end{tabular}


UND-EERC SEMPC Mineral Classification Ver. 3.1, Run Date: Dec 171992 4949

BULK CHEMICAL COMPOSITION

\begin{tabular}{lcrrrr}
\hline & $\mathrm{A}$ & $\mathrm{B}$ & $\mathrm{C}$ & $\mathrm{D}$ & $\mathrm{E}$ \\
\hline $\mathrm{SiO}_{2}$ & 2.8 & 3.3 & 37.3 & 4.4 & 4.6 \\
$\mathrm{Al}_{2} \mathrm{O}_{3}$ & 0.0 & 0.4 & 17.6 & 1.0 & 1.0 \\
$\mathrm{Fe}_{2} \mathrm{O}_{3}$ & 0.0 & 0.3 & 1.6 & 0.7 & 0.9 \\
$\mathrm{TiO}_{2}$ & 0.0 & 0.0 & 0.9 & 0.0 & 0.0 \\
$\mathrm{P}_{2} \mathrm{O}_{5}$ & 0.0 & 0.1 & 0.2 & 0.1 & 0.1 \\
$\mathrm{CaO}$ & 64.1 & 93.5 & 27.6 & 90.5 & 92.4 \\
$\mathrm{MgO}$ & 25.3 & 0.4 & 2.1 & 0.7 & 0.7 \\
$\mathrm{Na}_{2} \mathrm{O}$ & 0.0 & 0.0 & 0.0 & 0.0 & 0.0 \\
$\mathrm{~K}_{2} \mathrm{O}$ & 0.0 & 0.0 & 2.7 & 0.1 & 0.1 \\
$\mathrm{SO}_{3}$ & 3.2 & 0.7 & 2.6 & 1.1 & 0.0 \\
$\mathrm{Cl}_{2} \mathrm{O}_{7}$ & 4.6 & 1.1 & 6.3 & 1.3 & 0.0 \\
$\mathrm{Mn}_{2} \mathrm{O}_{7}$ & 0.0 & 0.1 & 0.7 & 0.1 & 0.1 \\
$\mathrm{BaO}$ & 0.0 & 0.0 & 0.4 & 0.0 & 0.0 \\
\hline
\end{tabular}

A. Cumulative bulk composition of OTHER.

B. Cumulative bulk composition of mixed-metal-rich.

C. Cumulative bulk composition of mixed-silicon-rich.

D. Cumulative bulk composition of the entire sample.

E. $\mathrm{SO}_{3^{-}}, \mathrm{Cl}_{2} \mathrm{O}_{7^{-}}, \mathrm{Cr}_{2} \mathrm{O}_{3^{-}}, \mathrm{BaO}$-free composition of the entire sample. 
UND-EERC SEMPC Mineral Classification Ver. 3.1, Run Date: Dec 171992

Using definitions file rules.c M263 Bed Material, Blend $800^{\circ} \mathrm{C}$ Gasification - 4950

\begin{tabular}{|c|c|c|c|}
\hline Mineral Name & Frequency, \% & Mineral Name & Frequency, \% \\
\hline Oxide-Rich & & Silicon-Rich & \\
\hline Magnesium Oxide & 0.0 & Quartz & 0.4 \\
\hline Aluminum Oxide & 0.0 & Albite & 0.0 \\
\hline Calcium Oxide & 4.8 & Anorthite & 0.0 \\
\hline Titanium Oxide & 0.0 & Potassium Feldspar & 0.0 \\
\hline Chromium Oxide & 0.0 & Nepheline & 0.0 \\
\hline Iron Oxide & 0.0 & Haüyne & 0.0 \\
\hline Spinel & 0.0 & Leucite & 0.0 \\
\hline Ca Ti Oxide & 0.0 & Kaolinite & 0.0 \\
\hline Ca Al Oxide & 0.0 & Altered Kaolinite & 0.0 \\
\hline Mixed-Oride-Rich & 0.4 & Illite & 0.0 \\
\hline \multirow[t]{2}{*}{ Total for Group } & 5.2 & Montmorillonite & 0.0 \\
\hline & & Pyroxene & 0.0 \\
\hline Sulfur-Rich & & Wollastonite & 0.0 \\
\hline Pyrite & 2.4 & Ca Silicate & 0.0 \\
\hline Pyrrhotite & 0.0 & Dicalcium Silicate & 0.0 \\
\hline Iron Sulfate & 0.0 & $\mathrm{NaCaSiO}_{3}$ & 0.0 \\
\hline Sodium Sulfate & 0.0 & Gehlenite & 0.0 \\
\hline Calcium Sulfate & 0.4 & Akermanite & 0.0 \\
\hline $\mathrm{Na} \mathrm{Ca}$ Sulfate & 0.0 & Merwinite & 0.0 \\
\hline Barite & 0.0 & Spurrite & 0.0 \\
\hline Mixed-Sulfur-Rich & 3.2 & Mullite & 0.0 \\
\hline \multirow[t]{2}{*}{ Total for Group } & 6.0 & Mixed-Silicon-Rich & 0.4 \\
\hline & & Total for Group & 0.8 \\
\hline \multicolumn{4}{|l|}{ Phosphorous-Rich } \\
\hline Apatite & 0.0 & & \\
\hline Mixed-Phosphorous-Rich & 0.4 & User-Defined-List & \\
\hline \multirow[t]{2}{*}{ Total for Group } & 0.4 & Ettringite & 0.0 \\
\hline & & Calcium Aluminate & 0.0 \\
\hline Carbon-Rich & & Total for Group & 0.0 \\
\hline Calcite & 60.2 & & \\
\hline Altered Calcite & 19.3 & & \\
\hline Dolomite & 0.0 & & \\
\hline Sulfated Dolomite & 0.0 & OTHER & 0.4 \\
\hline Ankerite & 0.8 & & \\
\hline Sulfated Ankerite & 0.0 & & \\
\hline Mixed-Carbon-Rich & 6.8 & & \\
\hline Total for Group & 87.1 & & \\
\hline \multicolumn{4}{|l|}{ Metal-Rich } \\
\hline Aluminum & 0.0 & & \\
\hline Titanium & 0.0 & & \\
\hline Iron & 0.0 & & \\
\hline Nickel & 0.0 & & \\
\hline Copper & 0.0 & & \\
\hline Chromium & 0.0 & & \\
\hline Mixed-Metal-Rich & 0.0 & & \\
\hline \multirow[t]{2}{*}{ Total for Group } & 0.0 & & \\
\hline & & & 249 \\
\hline \multicolumn{4}{|c|}{ TOTAL NUMBER OF POINTS ANALYZED } \\
\hline \multicolumn{3}{|c|}{ Carbon Threshhold for Analysis } & 250 \\
\hline \multicolumn{2}{|l|}{ Oxygen Threshhold for Analysis } & & 100 \\
\hline
\end{tabular}


UND-EERC SEMPC Mineral Classification Ver. 3.1, Run Date: Dec 171992

4950

BULK CHEMICAL COMPOSITION

\begin{tabular}{lrrrrrrrl}
\hline & \multicolumn{1}{c}{$\mathrm{A}$} & \multicolumn{1}{c}{$\mathrm{B}$} & \multicolumn{1}{c}{$\mathrm{C}$} & \multicolumn{1}{c}{$\mathrm{D}$} & \multicolumn{1}{c}{$\mathrm{E}$} & \multicolumn{1}{c}{$\mathrm{F}$} & $\mathrm{G}$ & $\mathrm{H}$ \\
\hline $\mathrm{SiO}_{2}$ & 5.5 & 13.6 & 7.7 & 0.0 & 24.8 & 38.7 & 3.6 & 3.9 \\
$\mathrm{Al}_{2} \mathrm{O}_{3}$ & 8.6 & 11.0 & 3.6 & 0.0 & 1.5 & 11.4 & 0.7 & 0.8 \\
$\mathrm{Fe}_{2} \mathrm{O}_{3}$ & 3.1 & 0.4 & 6.1 & 0.0 & 60.9 & 0.0 & 5.8 & 7.6 \\
$\mathrm{TiO}_{2}$ & 0.0 & 0.0 & 0.0 & 0.0 & 0.0 & 0.0 & 0.1 & 0.1 \\
$\mathrm{P}_{2} \mathrm{O}_{5}$ & 0.0 & 0.0 & 1.4 & 31.1 & 0.8 & 0.0 & 0.4 & 0.5 \\
$\mathrm{CaO}$ & 68.8 & 72.7 & 42.4 & 0.0 & 2.8 & 0.0 & 82.7 & 84.7 \\
$\mathrm{MgO}$ & 3.1 & 0.5 & 3.7 & 33.8 & 2.8 & 49.9 & 1.5 & 1.8 \\
$\mathrm{Na}_{2} \mathrm{O}$ & 1.9 & 0.0 & 1.7 & 0.0 & 2.3 & 0.0 & 0.5 & 0.6 \\
$\mathrm{~K}_{2} \mathrm{O}$ & 0.0 & 1.9 & 0.1 & 0.0 & 0.1 & 0.0 & 0.1 & 0.1 \\
$\mathrm{SO}_{3}$ & 8.6 & 0.0 & 29.8 & 0.0 & 1.7 & 0.0 & 3.9 & 0.0 \\
$\mathrm{Cl}_{2} \mathrm{O}_{7}$ & 0.0 & 0.0 & 2.4 & 35.1 & 2.2 & 0.0 & 0.6 & 0.0 \\
$\mathrm{Cr}_{2} \mathrm{O}_{3}$ & 0.4 & 0.0 & 0.9 & 0.0 & 0.0 & 0.0 & 0.1 & 0.0 \\
$\mathrm{BaO} \mathrm{O}$ & 0.0 & 0.0 & 0.0 & 0.0 & 0.0 & 0.0 & 0.0 & 0.0 \\
\hline
\end{tabular}
A. Cumulative bulk composition of OTHER.
B. Cumulative bulk composition of mixed-oxide-rich.
C. Cumulative bulk composition of mixed-sulfur-rich.
D. Cumulative bulk composition of mixed-phosphorous-rich.
E. Cumulative bulk composition of mixed-carbon-rich.
F. Cumulative bulk composition of mixed-silicon-rich.
$\mathrm{G}$. Cumulative bulk composition of the entire sample.
H. $\mathrm{SO}_{3^{-}}, \mathrm{Cl}_{2} \mathrm{O}_{7^{-}}, \mathrm{Cr}_{2} \mathrm{O}_{3^{-}}, \mathrm{BaO}$-free composition of the entire sample. 
UND-EERC SEMPC Mineral Classification Ver. 3.1, Run Date: Dec 171992

Using definitions file rules.c

M263 Wall Deposit, Blend $800^{\circ} \mathrm{C}$ Gasification - 4951

\begin{tabular}{|c|c|c|c|}
\hline Mineral Name & Frequency, \% & Mineral Name & Frequency, \% \\
\hline Oxide-Rich & & Silicon-Rich & \\
\hline Magnesium Oxide & 0.0 & Quartz & 0.0 \\
\hline Aluminum Oxide & 0.0 & Albite & 0.0 \\
\hline Calcium Oxide & 0.0 & Anorthite & 0.0 \\
\hline Titanium Oxide & 0.0 & Potassium Feldspar & 0.0 \\
\hline Chromium Oxide & 0.0 & Nepheline & 0.0 \\
\hline Iron Oxide & 0.0 & Haüyne & 0.0 \\
\hline Spinel & 0.0 & Leucite & 0.0 \\
\hline Ca Ti Oxide & 0.0 & Kaolinite & 0.0 \\
\hline $\mathrm{Ca}$ Al Oxide & 0.0 & Altered Kaolinite & 0.0 \\
\hline Mixed-Oxide-Rich & 0.0 & Illite & 0.0 \\
\hline \multirow[t]{2}{*}{ Total for Group } & 0.0 & Montmorillonite & 0.0 \\
\hline & & Pyrozene & 0.8 \\
\hline Sulfur-Rich & & Wollastonite & 0.0 \\
\hline Pyrite & 0.8 & Ca Silicate & 0.8 \\
\hline Pyrrhotite & 0.8 & Dicalcium Silicate & 4.0 \\
\hline Iron Sulfate & 0.0 & $\mathrm{NaCaSiO}_{3}$ & 0.8 \\
\hline Sodium Sulfate & 0.0 & Gehlenite & 0.8 \\
\hline Calciun Sulfate & 8.8 & Akermanite & 0.0 \\
\hline $\mathrm{Na}$ Ca Sulfate & 1.6 & Merwinite & 0.0 \\
\hline Barite & 0.0 & Spurrite & 0.0 \\
\hline Mixed-Sulfur-Rich & 8.0 & Mullite & 0.0 \\
\hline \multirow[t]{2}{*}{ Total for group } & 20.0 & Mixed-Silicon-Rich & 22.4 \\
\hline & & Total for Group & 29.6 \\
\hline \multicolumn{4}{|l|}{ Phosphorous-Rich } \\
\hline Apatite & 0.0 & & \\
\hline Mixed-Phosphorous-Rich & 0.0 & User-Defined-List & \\
\hline \multirow[t]{2}{*}{ Total for Group } & 0.0 & Ettringite & 0.0 \\
\hline & & Calcium Aluminate & 0.0 \\
\hline Carbon-Rich & & Total for Group & 0.0 \\
\hline Calcite & 0.0 & & \\
\hline Altered Calcite & 0.0 & & \\
\hline Dolomite & 0.0 & & \\
\hline Sulfated Dolomite & 0.0 & OTHER & 37.6 \\
\hline Ankerite & 0.0 & & \\
\hline Sulfated Ankerite & 0.0 & & \\
\hline Mixed-Carbon-Rich & 0.0 & & \\
\hline Total for Group & 0.0 & & \\
\hline \multicolumn{4}{|l|}{ Metal-Rich } \\
\hline Aluminum & 0.0 & & \\
\hline Titanium & 0.0 & & \\
\hline Iron & 2.4 & & \\
\hline Nickel & 0.0 & & \\
\hline Copper & 0.0 & & \\
\hline Chromium & 0.0 & & \\
\hline Mixed-Metal-Rich & 10.4 & & \\
\hline Total for Group & 12.8 & & \\
\hline \multicolumn{3}{|c|}{ TOTAL NUMBER OF POINTS ANALYZED } & 125 \\
\hline \multicolumn{3}{|c|}{ Carbon Threshhold for Analysis } & 250 \\
\hline \multicolumn{3}{|l|}{ Oxygen Threshhold for Analysis } & 100 \\
\hline
\end{tabular}


UND-EERC SEMPC Mineral Classification Ver. 3.1, Run Date: Dec 171992

4951

BULK CHEMICAL COMPOSITION

\begin{tabular}{lrrrrrr}
\hline & \multicolumn{1}{c}{$\mathrm{A}$} & $\mathrm{B}$ & $\mathrm{C}$ & $\mathrm{D}$ & $\mathrm{E}$ & $\mathrm{F}$ \\
\hline $\mathrm{SiO}_{2}$ & 5.6 & 5.6 & 2.1 & 27.0 & 10.8 & 11.5 \\
$\mathrm{Al}_{2} \mathrm{O}_{3}$ & 15.7 & 4.8 & 20.3 & 5.4 & 10.1 & 10.9 \\
$\mathrm{Fe}_{2} \mathrm{O}_{3}$ & 17.2 & 2.9 & 33.7 & 3.9 & 14.4 & 15.6 \\
$\mathrm{TiO}_{2}$ & 0.2 & 0.4 & 0.3 & 0.1 & 0.2 & 0.3 \\
$\mathrm{P}_{2} \mathrm{O}_{5}$ & 0.2 & 0.1 & 0.0 & 0.4 & 0.2 & 0.2 \\
$\mathrm{CaO}$ & 35.5 & 40.3 & 34.8 & 44.2 & 38.8 & 47.0 \\
$\mathrm{MgO}$ & 13.0 & 6.4 & 2.8 & 3.9 & 6.9 & 7.7 \\
$\mathrm{Na}_{2} \mathrm{O}$ & 3.9 & 2.7 & 2.0 & 9.4 & 4.8 & 5.2 \\
$\mathrm{~K}_{2} \mathrm{O}$ & 0.1 & 0.0 & 0.0 & 0.2 & 0.1 & 0.1 \\
$\mathrm{SO}_{3}$ & 3.6 & 31.4 & 1.3 & 2.9 & 10.2 & 0.3 \\
$\mathrm{Cl}_{2} \mathrm{O}_{7}$ & 3.4 & 4.2 & 0.7 & 1.9 & 2.2 & 0.1 \\
$\mathrm{Mn}_{2} \mathrm{O}_{7}$ & 1.3 & 0.3 & 1.8 & 0.2 & 1.0 & 1.1 \\
$\mathrm{BaO}$ & 0.3 & 0.9 & 0.0 & 0.5 & 0.3 & 0.0 \\
\hline
\end{tabular}

A. Cumulative bulk composition of OTHER.

B. Cumulative bulk composition of mixed-sulfur-rich.

C. Cumulative bulk composition of mixed-metal-rich.

D. Cumulative bulk composition of mixed-silicon-rich.

E. Cumulative bulk composition of the entire sample.

F. $\mathrm{SO}_{3}-, \mathrm{Cl}_{2} \mathrm{O}_{7}-, \mathrm{Cr}_{2} \mathrm{O}_{3}-, \mathrm{BaO}$-free composition of the entire sample. 
UND-EERC SEMPC Mineral Classification Ver. 3.1, Run Date: Dec 171992

Using definitions file rules.c

M264 Bed Material, Blend $850^{\circ} \mathrm{C}$ Gasification - 4952

\begin{tabular}{|c|c|c|c|}
\hline Mineral Name & Frequency, \% & Mineral Name & Frequency, $\%$ \\
\hline Oxide-Rich & & Silicon-Rich & \\
\hline Magnesium Oxide & 0.0 & Quartz & 6.0 \\
\hline Aluminum Oxide & 0.0 & Albite & 0.0 \\
\hline Calcium Oxide & 2.8 & Anorthite & 0.0 \\
\hline Titanium Oxide & 0.0 & Potassium Feldspar & 0.0 \\
\hline Chromium Oxide & 0.0 & Nepheline & 0.0 \\
\hline Iron Oxide & 1.6 & Haüyne & 0.0 \\
\hline Spinel & 0.0 & Leucite & 0.0 \\
\hline Ca Ti Oxide & 0.0 & Kaolinite & 0.4 \\
\hline Ca Al Oxide & 0.0 & Altered Kaolinite & 0.0 \\
\hline Mixed-Oxide-Rich & 0.8 & Illite & 0.0 \\
\hline \multirow[t]{2}{*}{ Total for Group } & 5.2 & Montmorillonite & 0.4 \\
\hline & & Pyroxene & 0.0 \\
\hline Sulfur-Rich & & Wollastonite & 0.0 \\
\hline Pyrite & 0.4 & Ca Silicate & 0.0 \\
\hline Pyrrhotite & 0.0 & Dicalcium Silicate & 0.0 \\
\hline Iron Sulfate & 0.0 & $\mathrm{NaCaSiO}_{3}$ & 0.0 \\
\hline Sodium Sulfate & 0.0 & Gehlenite & 0.0 \\
\hline Calcium Sulfate & 0.8 & Akermanite & 0.0 \\
\hline Na Ca Sulfate & 0.0 & Merwinite & 0.0 \\
\hline Barite & 0.0 & Spurrite & 0.0 \\
\hline Mixed-Sulfur-Rich & 6.0 & Mullite & 0.0 \\
\hline \multirow{2}{*}{ Total for Group } & 7.2 & Mired-Silicon-Rich & 0.8 \\
\hline & & Total for Group & 7.6 \\
\hline \multicolumn{4}{|l|}{ Phosphorous-Rich } \\
\hline Apatite & 0.0 & & \\
\hline Mixed-Phosphorous-Rich & 0.0 & User-Defined-List & \\
\hline \multirow[t]{2}{*}{ Total for Group } & 0.0 & Ettringite & 0.0 \\
\hline & & Calcium Aluminate & 0.0 \\
\hline Carbon-Rich & & Total for Group & 0.0 \\
\hline Calcite & 44.2 & & \\
\hline Altered Calcite & 26.5 & & \\
\hline Dolomite & 0.0 & & \\
\hline Sulfated Dolomite & 0.0 & OTHER & 0.0 \\
\hline Ankerite & 0.4 & & \\
\hline Sulfated Ankerite & 0.0 & & \\
\hline Mixed-Carbon-Rich & 8.8 & & \\
\hline Total for Group & 79.9 & & \\
\hline \multicolumn{4}{|l|}{ Metal-Rich } \\
\hline Aluminum & 0.0 & & \\
\hline Titanium & 0.0 & & \\
\hline Iron & 0.0 & & \\
\hline Nickel & 0.0 & & \\
\hline Copper & 0.0 & & \\
\hline Chromium & 0.0 & & \\
\hline Mixed-Metal-Rich & 0.0 & & \\
\hline \multirow[t]{2}{*}{ Total for Group } & 0.0 & & \\
\hline & & & 249 \\
\hline \multicolumn{4}{|c|}{ TOTAL NUMBER OF POINTS ANALYZED } \\
\hline \multirow{2}{*}{\multicolumn{3}{|c|}{ Carbon Threshhold for Analysis }} & 250 \\
\hline & & Oxygen Threshhold for Analysis & 100 \\
\hline
\end{tabular}


UND-EERC SEMPC Mineral Classification Ver. 3.1, Run Date: Dec 171992 4952

BULI CHEMICAL COMPOSITION

\begin{tabular}{lrrrrrr}
\hline & \multicolumn{1}{c}{$\mathrm{A}$} & $\mathrm{B}$ & $\mathrm{C}$ & $\mathrm{D}$ & $\mathrm{E}$ & $\mathrm{F}$ \\
\hline $\mathrm{SiO}_{2}$ & 0.6 & 7.3 & 21.2 & 60.4 & 10.4 & 10.6 \\
$\mathrm{Al}_{2} \mathrm{O}_{3}$ & 0.4 & 1.4 & 3.4 & 28.0 & 1.3 & 1.4 \\
$\mathrm{Fe}_{2} \mathrm{O}_{3}$ & 36.9 & 1.5 & 63.4 & 0.5 & 7.8 & 8.5 \\
$\mathrm{TiO}_{2}$ & 0.0 & 0.0 & 0.1 & 0.0 & 0.1 & 0.1 \\
$\mathrm{P}_{2} \mathrm{O}_{5}$ & 0.2 & 2.3 & 0.1 & 0.0 & 0.3 & 0.3 \\
$\mathrm{CaO}$ & 0.6 & 48.0 & 2.0 & 0.5 & 72.6 & 76.2 \\
$\mathrm{MgO}$ & 0.0 & 0.8 & 0.6 & 0.6 & 0.9 & 1.0 \\
$\mathrm{Na}_{2} \mathrm{O}$ & 38.2 & 2.1 & 4.8 & 4.2 & 1.5 & 1.8 \\
$\mathrm{~K}_{2} \mathrm{O}$ & 0.2 & 0.4 & 0.3 & 5.6 & 0.2 & 0.2 \\
$\mathrm{SO}_{3}$ & 1.5 & 35.8 & 1.3 & 0.0 & 4.0 & 0.0 \\
$\mathrm{Cl}_{2} \mathrm{O}_{7}$ & 0.2 & 0.2 & 0.7 & 0.2 & 0.4 & 0.0 \\
$\mathrm{Cr}_{2} \mathrm{O}_{3}$ & 21.1 & 0.2 & 2.2 & 0.0 & 0.5 & 0.0 \\
$\mathrm{BaO}$ & 0.0 & 0.0 & 0.0 & 0.1 & 0.0 & 0.0 \\
\hline
\end{tabular}

A. Cumulative bulk composition of mixed-oxide-rich.

B. Cumulative bulk composition of mixed-sulfur-rich.

C. Cumulative bulk composition of mixed-carbon-rich.

D. Cumulative bulk composition of mixed-sicon-rich.

E. Cumulative bulk composition of the entire sample.

F. $\mathrm{SO}_{3}, \mathrm{Cl}_{2} \mathrm{O}_{7}{ }^{-}, \mathrm{Cr}_{2} \mathrm{O}_{3}{ }^{\circ}, \mathrm{BaO}$-free composition of the entire sample. 
UND-EERC SEMPC Mineral Classification Ver. 3.1, Run Date: Dec 171992

Using definitions file rules.c

M265 Bed Material, Blend $850^{\circ} \mathrm{C}$ Gasification, No Limestone - 4954

\begin{tabular}{|c|c|c|c|}
\hline Mineral Name & Frequency, $\%$ & Mineral Name & Frequency, \% \\
\hline Oxide-Rich & & Silicon-Rich & \\
\hline Magnesium Oxide & 0.0 & Quartz & 0.0 \\
\hline Aluminæm Oxide & 0.0 & Albite & 0.0 \\
\hline Calcium Oxide & 0.0 & Anorthite & 0.0 \\
\hline Titanium Oxide & 0.0 & Potassium Feldspar & 0.0 \\
\hline Chromium Oxide & 0.0 & Nepheline & 0.0 \\
\hline Iron Oxide & 3.6 & Hauyne & 0.0 \\
\hline Spinel & 0.0 & Leucite & 0.0 \\
\hline Ca Ti Oxide & 0.0 & Kaolinite & 1.6 \\
\hline $\mathrm{Ca} \mathrm{Al}$ Oxide & 0.0 & Altered Kaolinite & 0.0 \\
\hline Mised-Oxide-Rich & 0.0 & Illite & 0.0 \\
\hline \multirow[t]{2}{*}{ Total for Group } & 3.6 & Montmorillonite & 0.0 \\
\hline & & Pyroxene & 0.4 \\
\hline Sulfur-Rich & & Wollastonite & 0.0 \\
\hline Pyrite & 23.2 & Ca Silicate & 0.0 \\
\hline Pyrrhatite & 4.4 & Dicalcium Silicate & 0.0 \\
\hline Iron Sulfate & 2.4 & $\mathrm{NaCaSiO}_{3}$ & 0.0 \\
\hline Sodium Sulfate & 0.0 & Gehlenite & 0.0 \\
\hline Calcium Sulfate & 0.0 & Akermanite & 0.0 \\
\hline Na Ca Sulfate & 0.0 & Merwinite & 0.0 \\
\hline Barite & 0.0 & Spurrite & 0.0 \\
\hline Mixed-Sulfur-Rich & 2.8 & Mullite & 0.0 \\
\hline \multirow[t]{2}{*}{ Total for Group } & 32.8 & Mized-Silicon-Rich & 10.4 \\
\hline & & Total for Group & 12.4 \\
\hline \multicolumn{4}{|l|}{ Phosphorous-Rich } \\
\hline Apatite & 0.0 & & \\
\hline Mixed-Phosphorous-Rich & 0.0 & User-Defined-List & \\
\hline \multirow[t]{2}{*}{ Total for Group } & 0.0 & Ettringite & 0.0 \\
\hline & & Calcium Aluminate & 0.0 \\
\hline Carbon-Rich & & Total for Group & 0.0 \\
\hline Calcite & 5.2 & & \\
\hline Altered Calcite & 1.2 & & \\
\hline Dolomite & 0.0 & & \\
\hline Sulfated Dolomite & 0.0 & OTHER & 1.2 \\
\hline Ankerite & 0.0 & & \\
\hline Sulfated Ankerite & 0.0 & & \\
\hline Mixed-Carbon-Rich & 43.6 & & \\
\hline Total for Group & 50.0 & & \\
\hline \multicolumn{4}{|l|}{ Metal-Rich } \\
\hline Aluminum & 0.0 & & \\
\hline Titanium & 0.0 & & \\
\hline Iron & 0.0 & & \\
\hline Nickel & 0.0 & & \\
\hline Copper & 0.0 & & \\
\hline Chromium & 0.0 & & \\
\hline Mixed-Metal-Rich & 0.0 & & \\
\hline \multirow[t]{2}{*}{ Total for Group } & 0.0 & & \\
\hline & & & 250 \\
\hline \multicolumn{4}{|c|}{ TOTAL NUMBER OF POINTS ANALYZED } \\
\hline \multicolumn{3}{|c|}{ Carbon Threshhold for Analysis } & 250 \\
\hline \multicolumn{2}{|l|}{ Oxygen Threshbold for Analysis } & & 100 \\
\hline
\end{tabular}


UND-EERC SEMPC Mineral Classification Ver. 3.1, Run Date: Dec 171992 4954

BULK CHEMICAL COMPOSITION

\begin{tabular}{lrrrrrr}
\hline & \multicolumn{1}{c}{$\mathrm{A}$} & $\mathrm{B}$ & $\mathrm{C}$ & $\mathrm{D}$ & $\mathrm{E}$ & $\mathrm{F}$ \\
\hline $\mathrm{SiO}_{2}$ & 0.0 & 4.7 & 17.5 & 62.3 & 15.4 & 15.1 \\
$\mathrm{Al}_{2} \mathrm{O}_{3}$ & 23.9 & 0.2 & 10.4 & 26.9 & 9.0 & 8.7 \\
$\mathrm{Fe}_{2} \mathrm{O}_{3}$ & 1.4 & 2.7 & 64.2 & 2.7 & 47.8 & 58.7 \\
$\mathrm{TiO}_{2}$ & 0.1 & 1.1 & 0.0 & 0.0 & 0.1 & 0.5 \\
$\mathrm{P}_{2} \mathrm{O}_{5}$ & 0.0 & 0.0 & 0.1 & 0.0 & 0.1 & 0.1 \\
$\mathrm{CaO}$ & 44.2 & 0.7 & 1.4 & 2.4 & 6.5 & 6.5 \\
$\mathrm{MgO}$ & 8.9 & 2.2 & 1.4 & 3.6 & 1.6 & 1.9 \\
$\mathrm{Na}_{2} \mathrm{O}$ & 18.3 & 5.0 & 1.9 & 1.0 & 2.1 & 3.4 \\
$\mathrm{~K}_{2} \mathrm{O}$ & 0.1 & 0.0 & 0.2 & 0.5 & 0.2 & 0.2 \\
$\mathrm{SO}_{3}$ & 2.1 & 65.7 & 2.1 & 0.3 & 16.2 & 3.6 \\
$\mathrm{Cl}_{2} \mathrm{O}_{7}$ & 0.5 & 2.1 & 0.7 & 0.3 & 0.5 & 0.0 \\
$\mathrm{Cr}_{2} \mathrm{O}_{3}$ & 0.1 & 0.1 & 0.1 & 0.0 & 0.1 & 0.0 \\
$\mathrm{BaO}$ & 0.2 & 15.6 & 0.0 & 0.0 & 0.5 & 1.4 \\
\hline
\end{tabular}
A. Cumulative bulk composition of OTHER.
B. Cumulative bulk composition of mixed-sulfur-rich.
C. Cumulative bulk composition of mixed-carbon-rich.
D. Cumulative bulk composition of mixed-silicon-rich.
$\mathrm{E}$. Cumulative bulk composition of the entire sample.
F. $\mathrm{SO}_{3^{-}}, \mathrm{Cl}_{2} \mathrm{O}_{7^{-}}, \mathrm{Cr}_{2} \mathrm{O}_{3^{-}}, \mathrm{BaO}$-free composition of the entire sample. 
UND-EERC SEMPC Mineral Classification Ver. 3.1, Run Date: Dec 171992

Using definitions file rules.c

Bed Material, Blend $850^{\circ} \mathrm{C}$ Combustion - 4982

\begin{tabular}{|c|c|c|c|}
\hline Mineral Name & Frequency, $\%$ & Mineral Name & Frequency, $\%$ \\
\hline Oxide-Rich & & Silicon-Rich & \\
\hline Magnesium Oxide & 0.4 & Quartz & 0.4 \\
\hline Aluminum Oxide & 0.0 & Albite & 0.0 \\
\hline Calcium Oxide & 4.4 & Anorthite & 0.0 \\
\hline Titanium Oxide & 0.0 & Potassium Feldspar & 0.0 \\
\hline Chromium Oxide & 0.0 & Nepheline & 0.0 \\
\hline Iron Oxide & 0.0 & Haüyne & 0.0 \\
\hline Spinel & 0.0 & Leucite & 0.0 \\
\hline Ca Ti Oxide & 0.0 & Kaolinite & 0.0 \\
\hline $\mathrm{Ca} \mathrm{Al}$ Oxide & 0.0 & Altered Kaolinite & 0.0 \\
\hline Mixed-Oxide-Rich & 1.6 & Illite & 0.0 \\
\hline \multirow[t]{2}{*}{ Total for Group } & 6.4 & Montmorillonite & 0.0 \\
\hline & & Pyrozene & 3.6 \\
\hline Sulfur-Rich & & Wollastonite & 0.4 \\
\hline Pyrite & 0.0 & Ca Silicate & 3.6 \\
\hline Pyrrhotite & 0.0 & Dicalcium Silicate & 0.0 \\
\hline Iron Sulfate & 0.0 & $\mathrm{NaCaSiO}_{3}$ & 0.0 \\
\hline Sodium Sulfate & 0.0 & Gehlenite & 0.8 \\
\hline Calcium Sulfate & 1.6 & Akermanite & 0.0 \\
\hline Na Ca Sulfate & 2.4 & Merwinite & 0.0 \\
\hline Barite & 0.0 & Spurrite & 0.0 \\
\hline Mixed-Sulfur-Rich & 2.4 & Mullite & 0.0 \\
\hline \multirow[t]{2}{*}{ Total for Group } & 6.4 & Mixed-Silicon-Rich & 8.0 \\
\hline & & Total for Group & 16.9 \\
\hline \multicolumn{4}{|l|}{ Phosphorous-Rich } \\
\hline Apatite & 0.0 & & \\
\hline Mixed-Phosphorous-Rich & 0.0 & User-Defined-List & \\
\hline \multirow[t]{2}{*}{ Total for Group } & 0.0 & Ettringite & 0.0 \\
\hline & & Calcium Aluminate & 0.0 \\
\hline Carbon-Rich & & Total for Group & 0.0 \\
\hline Calcite & 46.6 & & \\
\hline Altered Calcite & 2.4 & & \\
\hline Dolomite & 0.4 & & \\
\hline Sulfated Dolomite & 0.0 & OTHER & 7.6 \\
\hline Ankerite & 2.4 & & \\
\hline Sulfated Ankerite & 0.0 & & \\
\hline Mixed-Carbon-Rich & 6.4 & & \\
\hline Total for Group & 58.2 & & \\
\hline \multicolumn{4}{|l|}{ Metal-Rich } \\
\hline Aluminum & 0.0 & & \\
\hline Titanium & 0.0 & & \\
\hline Iron & 0.0 & & \\
\hline Nickel & 0.0 & & \\
\hline Copper & 0.0 & & \\
\hline Chromium & 0.0 & & \\
\hline Mixed-Metal-Rich & 4.4 & & \\
\hline \multirow[t]{2}{*}{ Total for Group } & 4.4 & & \\
\hline & & & 249 \\
\hline \multicolumn{4}{|c|}{ TOTAL NUMBER OF POINTS ANALYZED } \\
\hline Carbon Threshhold for Analysis & & & 250 \\
\hline Oxygen Threshhold for Analysis & & & 100 \\
\hline
\end{tabular}


UND-EERC SEMPC Mineral Classification Ver. 3.1, Run Date: Dec 171992 4982

BULK CHEMICAL COMPOSITION

\begin{tabular}{lrrrrrrrr}
\hline & \multicolumn{1}{c}{$\mathrm{A}$} & \multicolumn{1}{c}{$\mathrm{B}$} & \multicolumn{1}{c}{$\mathrm{C}$} & \multicolumn{1}{c}{$\mathrm{D}$} & $\mathrm{E}$ & $\mathrm{F}$ & $\mathrm{G}$ & $\mathrm{H}$ \\
\hline $\mathrm{SiO}_{2}$ & 5.7 & 3.1 & 2.3 & 43.3 & 2.6 & 27.7 & 16.6 & 17.2 \\
$\mathrm{Al}_{2} \mathrm{O}_{3}$ & 16.6 & 17.0 & 4.1 & 11.5 & 4.5 & 19.2 & 7.5 & 7.9 \\
$\mathrm{Fe}_{2} \mathrm{O}_{3}$ & 16.4 & 28.8 & 9.8 & 11.2 & 3.9 & 5.4 & 6.6 & 7.0 \\
$\mathrm{TiO}_{2}$ & 0.4 & 0.3 & 0.2 & 0.2 & 0.1 & 0.2 & 0.2 & 0.2 \\
$\mathrm{P}_{2} \mathrm{O}_{5}$ & 0.1 & 0.0 & 0.0 & 0.3 & 0.4 & 0.2 & 0.3 & 0.3 \\
$\mathrm{CaO} \mathrm{O}$ & 41.4 & 48.6 & 35.1 & 11.3 & 84.2 & 35.0 & 55.0 & 58.7 \\
$\mathrm{MgO}$ & 12.1 & 0.5 & 11.7 & 8.4 & 0.6 & 3.7 & 4.3 & 4.6 \\
$\mathrm{Na}_{2} \mathrm{O}$ & 2.9 & 0.5 & 6.4 & 6.8 & 0.8 & 6.1 & 3.5 & 4.0 \\
$\mathrm{~K}_{2} \mathrm{O}$ & 0.0 & 0.0 & 0.1 & 0.4 & 0.0 & 0.0 & 0.1 & 0.1 \\
$\mathrm{SO}_{3}$ & 3.2 & 0.8 & 29.7 & 2.5 & 2.6 & 2.0 & 4.8 & 0.0 \\
$\mathrm{Cl}_{2} \mathrm{O}_{7}$ & 0.1 & 0.3 & 0.4 & 3.5 & 0.2 & 0.1 & 0.9 & 0.0 \\
$\mathrm{Cr}_{2} \mathrm{O}_{3}$ & 0.9 & 0.0 & 0.1 & 0.2 & 0.1 & 0.2 & 0.3 & 0.0 \\
$\mathrm{BaO}$ & 0.1 & 0.0 & 0.1 & 0.4 & 0.0 & 0.1 & 0.1 & 0.0 \\
\hline $\mathrm{A}$ & & 0.1 & & & &
\end{tabular}
A. Cumulative bulk composition of OTHER.
B. Cumulative bulk composition of mixed-oxide-rich.
C. Cumulative bulk composition of mixed-sulfur-rich.
D. Cumulative bulk composition of mixed-carbon-rich.
E. Cumulative bulk composition of mixed-metal-rich.
F. Cumulative bulk composition of mixed-silicon-rich.
G. Cumulative bulk composition of the entire sample.
H. $\mathrm{SO}_{3-}, \mathrm{Cl}_{2} \mathrm{O}_{7}, \mathrm{Cr}_{2} \mathrm{O}_{3^{-}}, \mathrm{BaO}$-free composition of the entire sample. 
UND-EERC SEMPC Mineral Classification Ver. 3.1, Run Date: Dec 171992

Using definitions file rules.c

Bed Material, $850^{\circ} \mathrm{C}$ Blend Dolomite Gasification - 4983

\begin{tabular}{|c|c|c|c|}
\hline Mineral Name & Frequency, \% & Mineral Name & Frequency, \% \\
\hline Oxide-Rich & & Silicon-Rich & \\
\hline Magnesium Oxide & 0.0 & Quartz & 0.0 \\
\hline Aluminum Oxide & 0.0 & Albite & 0.0 \\
\hline Calcium Oxide & 0.0 & Anorthite & 0.0 \\
\hline Titanium Oxide & 0.0 & Potassium Feldspar & 0.0 \\
\hline Chromium Oxide & 0.0 & Nepheline & 0.0 \\
\hline Iron Oxide & 5.2 & Haüyne & 0.0 \\
\hline Spinel & 0.0 & Leucite & 0.0 \\
\hline Ca Ti Oxide & 0.0 & Kaolinite & 0.0 \\
\hline Ca Al Oxide & 0.0 & Altered Kaolinite & 0.0 \\
\hline Mixed-Oxide-Rich & 12.4 & Illite & 0.0 \\
\hline \multirow[t]{2}{*}{ Total for Group } & 17.7 & Montmorillonite & 0.0 \\
\hline & & Pyroxene & 0.4 \\
\hline Sulfur-Rich & & Wollastonite & 0.0 \\
\hline Pyrite & 0.4 & Ca Silicate & 0.0 \\
\hline Pyrrhotite & 0.0 & Dicalcium Silicate & 0.0 \\
\hline Iron Sulfate & 0.0 & $\mathrm{NaCaSiO}_{3}$ & 0.0 \\
\hline Sodium Sulfate & 0.0 & Gehlenite & 0.0 \\
\hline Calcium Sulfate & 0.0 & Akermanite & 0.0 \\
\hline $\mathrm{Na}$ Ca Sulfate & 0.0 & Merwinite & 0.0 \\
\hline Barite & 0.0 & Spurrite & 0.0 \\
\hline Mized-Sulfur-Rich & 7.6 & Mullite & 0.0 \\
\hline \multirow[t]{2}{*}{ Total for Group } & 8.0 & Mixed-Silicon-Rich & 0.0 \\
\hline & & Total for Group & 0.4 \\
\hline \multicolumn{4}{|l|}{ Phosphorous-Rich } \\
\hline Apatite & 0.0 & & \\
\hline Mixed-Phosphorous-Rich & 0.0 & User-Defined-List & \\
\hline \multirow[t]{2}{*}{ Total for Group } & 0.0 & Ettringite & 0.0 \\
\hline & & Calcium Aluminate & 0.0 \\
\hline Carbon-Rich & & Total for Group & 0.0 \\
\hline Calcite & 53.4 & & \\
\hline Altered Calcite & 0.0 & & \\
\hline Dolomite & 9.2 & & \\
\hline Sulfated Dolomite & 0.0 & OTHER & 0.0 \\
\hline Ankerite & 0.0 & & \\
\hline Sulfated Ankerite & 0.0 & & \\
\hline Mixed-Carbon-Rich & 11.2 & & \\
\hline Total for Group & 73.9 & & \\
\hline \multicolumn{4}{|l|}{ Metal-Rich } \\
\hline Aluminum & 0.0 & & \\
\hline Titanium & 0.0 & & \\
\hline Iron & 0.0 & & \\
\hline Nickel & 0.0 & & \\
\hline Copper & 0.0 & & \\
\hline Chromium & 0.0 & & \\
\hline Mixed-Metal-Rich & 0.0 & & \\
\hline \multirow[t]{2}{*}{ Total for Group } & 0.0 & & \\
\hline & & & 249 \\
\hline \multicolumn{4}{|c|}{ TOTAL NUMBER OF POINTS ANALYZED } \\
\hline Carbon Threshhold for Analysis & & & 250 \\
\hline Oxygen Threshhold for Analysis & & & 100 \\
\hline
\end{tabular}


UND-EERC SEMPC Mineral Classification Ver. 3.1, Run Date: Dec 171992 4983

BULK CHEMICAL COMPOSITION

\begin{tabular}{lrrrrr}
\hline & $\mathrm{A}$ & $\mathrm{B}$ & $\mathrm{C}$ & $\mathrm{D}$ & $\mathrm{E}$ \\
\hline $\mathrm{SiO}_{2}$ & 0.4 & 1.7 & 6.2 & 1.7 & 1.8 \\
$\mathrm{Al}_{2} \mathrm{O}_{3}$ & 0.0 & 0.6 & 1.7 & 0.3 & 0.3 \\
$\mathrm{Fe}_{2} \mathrm{O}_{3}$ & 0.2 & 0.6 & 71.2 & 13.6 & 14.3 \\
$\mathrm{TiO}_{2}$ & 0.1 & 0.0 & 0.0 & 0.0 & 0.0 \\
$\mathrm{P}_{2} \mathrm{O}_{5}$ & 0.1 & 0.0 & 0.1 & 0.1 & 0.1 \\
$\mathrm{CaO}$ & 48.4 & 28.1 & 2.2 & 38.0 & 39.9 \\
$\mathrm{MgO}$ & 49.4 & 30.5 & 12.4 & 40.7 & 42.7 \\
$\mathrm{Na}_{2} \mathrm{O}$ & 0.3 & 1.5 & 2.1 & 0.7 & 0.9 \\
$\mathrm{~K}_{2} \mathrm{O}$ & 0.1 & 0.0 & 0.1 & 0.0 & 0.0 \\
$\mathrm{SO}_{3}$ & 0.4 & 33.6 & 2.1 & 3.7 & 0.0 \\
$\mathrm{Cl}_{2} \mathrm{O}_{7}$ & 0.6 & 3.4 & 1.8 & 1.0 & 0.0 \\
$\mathrm{Cr}_{2} \mathrm{O}_{3}$ & 0.1 & 0.0 & 0.1 & 0.1 & 0.0 \\
$\mathrm{BaO}$ & 0.0 & 0.0 & 0.0 & 0.0 & 0.0 \\
\hline
\end{tabular}

A. Cumulative bulk composition of mixed-oxide-rich.

B. Cumulative bulk composition of mixed-sulfur-rich.

C. Cumulative bulk composition of mixed-carbon-rich.

D. Cumulative bulk composition of the entire sample.

E. $\mathrm{SO}_{3}, \mathrm{Cl}_{2} \mathrm{O}_{7^{-}}, \mathrm{Cr}_{2} \mathrm{O}_{3^{-}}, \mathrm{BaO}$-free composition of the entire sample. 
UND-EERC SEMPC Mineral Classification Ver. 3.1, Run Date: Dec 171992

Using definitions file rules.c

Bed Material, Blend $850^{\circ} \mathrm{C}$ with Emathlite Gasification - 4984

\begin{tabular}{|c|c|c|c|}
\hline Mineral Name & Frequency, \% & Mineral Name & Frequency, \% \\
\hline Oxide-Rich & & Silicon-Rich & \\
\hline Magnesium Oxide & 0.0 & Quartz & 0.8 \\
\hline Aluminum Oxide & 0.0 & Albite & 0.0 \\
\hline Calcium Oxide & 1.6 & Anorthite & 0.0 \\
\hline Titanium Oxide & 0.0 & Potassium Feldspar & 0.0 \\
\hline Chromium Oxide & 0.0 & Nepheline & 0.0 \\
\hline Iron Oxide & 0.4 & Haüyne & 0.0 \\
\hline Spinel & 0.0 & Leucite & 0.0 \\
\hline Ca Ti Oxide & 0.0 & Kaolinite & 0.8 \\
\hline Ca Al Oxide & 0.0 & Altered Kaolinite & 0.0 \\
\hline Mixed-Oxide-Rich & 0.0 & Illite & 0.0 \\
\hline \multirow[t]{2}{*}{ Total for Group } & 2.0 & Montmorillonite & 0.0 \\
\hline & & Pyroxene & 0.0 \\
\hline Sulfur-Rich & & Wollastonite & 0.0 \\
\hline Pyrite & 6.4 & Ca Silicate & 0.0 \\
\hline Pyrrhotite & 0.8 & Dicalcium Silicate & 0.0 \\
\hline Iron Sulfate & 6.8 & $\mathrm{NaCaSiO}_{3}$ & 0.0 \\
\hline Sodium Sulfate & 0.0 & Gehlenite & 0.0 \\
\hline Calcium Sulfate & 0.0 & Akermanite & 0.0 \\
\hline Na Ca Sulfate & 0.0 & Merwinite & 0.0 \\
\hline Barite & 0.0 & Spurrite & 0.0 \\
\hline Mixed-Sulfur-Rich & 1.2 & Mullite & 0.0 \\
\hline \multirow[t]{2}{*}{ Total for Group } & 15.3 & Mixed-Silicon-Rich & 0.0 \\
\hline & & Total for Group & 1.6 \\
\hline \multicolumn{4}{|l|}{ Phosphorous-Rich } \\
\hline Apatite & 0.0 & & \\
\hline Mixed-Phosphorous-Rich & 0.0 & User-Defined-List & \\
\hline \multirow[t]{2}{*}{ Total for Group } & 0.0 & Ettringite & 0.0 \\
\hline & & Calcium Aluminate & 0.0 \\
\hline Carbon-Rich & & Total for Group & 0.0 \\
\hline Calcite & 46.2 & & \\
\hline Altered Calcite & 11.6 & & \\
\hline Dolomite & 0.0 & & \\
\hline Sulfated Dolomite & 0.0 & OTHER & 0.0 \\
\hline Ankerite & 0.0 & & \\
\hline Sulfated Ankerite & 0.0 & & \\
\hline Mixed-Carbon-Rich & 22.9 & & \\
\hline Total for Group & 80.7 & & \\
\hline \multicolumn{4}{|l|}{ Metal-Rich } \\
\hline Aluminum & 0.0 & & \\
\hline Titanium & 0.0 & & \\
\hline Iron & 0.0 & & \\
\hline Nicirel & 0.0 & & \\
\hline Copper & 0.0 & & \\
\hline Chromium & 0.0 & & \\
\hline Mized-Metal-Rich & 0.4 & & \\
\hline \multirow[t]{2}{*}{ Total for Group } & 0.4 & & \\
\hline & & & 249 \\
\hline \multicolumn{4}{|c|}{ TOTAL NUMBER OF POINTS ANALYZED } \\
\hline Carbon Threshhold for Analysis & & & 250 \\
\hline Oxygen Threshhold for Analysis & & & 100 \\
\hline
\end{tabular}


UND-EERC SEMPC Mineral Classification Ver. 3.1, Run Date: Dec 171992 4984

BULK CHEMICAL COMPOSITION

\begin{tabular}{lrrrrr}
\hline & \multicolumn{1}{c}{$\mathrm{A}$} & $\mathrm{B}$ & $\mathrm{C}$ & $\mathrm{D}$ & $\mathrm{E}$ \\
\hline $\mathrm{SiO}_{2}$ & 19.4 & 23.9 & 0.0 & 8.1 & 8.6 \\
$\mathrm{Al}_{2} \mathrm{O}_{3}$ & 0.3 & 11.3 & 0.0 & 3.3 & 3.5 \\
$\mathrm{Fe}_{2} \mathrm{O}_{3}$ & 7.5 & 55.6 & 0.0 & 18.6 & 26.8 \\
$\mathrm{TiO}_{2}$ & 0.0 & 0.1 & 0.0 & 0.0 & 0.1 \\
$\mathrm{P}_{2} \mathrm{O}_{5}$ & 0.0 & 0.3 & 0.0 & 0.2 & 0.2 \\
$\mathrm{CaO}$ & 39.5 & 1.6 & 98.9 & 57.7 & 58.8 \\
$\mathrm{MgO}$ & 0.4 & 2.0 & 0.7 & 1.1 & 1.1 \\
$\mathrm{Na}_{2} \mathrm{O}$ & 0.1 & 2.2 & 0.4 & 0.8 & 0.9 \\
$\mathrm{~K}_{2} \mathrm{O}$ & 0.1 & 0.2 & 0.0 & 0.1 & 0.1 \\
$\mathrm{SO}_{3}$ & 30.9 & 0.6 & 0.0 & 9.1 & 0.0 \\
$\mathrm{Cl}_{2} \mathrm{O}_{7}$ & 1.8 & 2.2 & 0.0 & 1.0 & 0.0 \\
$\mathrm{Cr}_{2} \mathrm{O}_{3}$ & 0.0 & 0.1 & 0.0 & 0.1 & 0.0 \\
$\mathrm{BaO}$ & 0.0 & 0.0 & 0.0 & 0.0 & 0.0 \\
\hline
\end{tabular}
A. Cumulative bulk composition of mixed-sulfur-rich.
B. Cumulative bulk composition of mixed-carbon-rich.
C. Cumulative bulk composition of mixed-metal-rich.
D. Cumulative bulk composition of the entire sample.
E. $\mathrm{SO}_{3^{-}}, \mathrm{Cl}_{2} \mathrm{O}_{7^{-}}, \mathrm{Cr}_{2} \mathrm{O}_{3^{-}}, \mathrm{BaO}$-fiee composition of the entire sample. 
UND-EERC SEMPC Mineral Classification Ver. 3.1, Run Date: Dec 171992

Using definitions file rules.c

Bed Material, Blend $850^{\circ} \mathrm{C}$ with Calcium Sulfide Combustion - 4985

\begin{tabular}{|c|c|c|c|}
\hline Mineral Name & Frequency, \% & Mineral Name & Frequency, \% \\
\hline Oxide-Rich & & Silicon-Rich & \\
\hline Magnesium Oxide & 1.6 & Quartz & 0.0 \\
\hline Aluminum Oxide & 0.0 & Albite & 0.0 \\
\hline Calcium Oxide & 6.8 & Anorthite & 0.0 \\
\hline Titanium Oxide & 0.0 & Potassium Feldspar & 0.0 \\
\hline Chromium Oxide & 0.0 & Nepheline & 0.0 \\
\hline Iron Oxide & 0.0 & Haüyne & 0.0 \\
\hline Spinel & 0.0 & Leucite & 0.0 \\
\hline Ca Ti Oxide & 0.0 & Kaolinite & 0.0 \\
\hline Ca Al Oxide & 0.0 & Altered Kaolinite & 0.0 \\
\hline Mixed-Oxide-Rich & 1.2 & Illite & 0.0 \\
\hline \multirow[t]{2}{*}{ Total for Group } & 9.6 & Montmorillonite & 0.0 \\
\hline & & Pyroxene & 0.0 \\
\hline Sulfur-Rich & & Wollastonite & 0.0 \\
\hline Pyrite & 0.0 & Ca Silicate & 9.6 \\
\hline Pyrrhotite & 0.0 & Dicalcium Silicate & 0.8 \\
\hline Iron Sulfate & 0.0 & $\mathrm{NaCaSiO}_{3}$ & 0.0 \\
\hline Sodium Sulfate & 0.0 & Gehlenite & 0.4 \\
\hline Calcium Sulfate & 2.8 & Akermanite & 0.4 \\
\hline $\mathrm{Na}$ Ca Sulfate & 3.2 & Merwinite & 0.0 \\
\hline Barite & 0.0 & Spurrite & 0.4 \\
\hline Mixed-Sulfur-Rich & 14.1 & Mullite & 0.0 \\
\hline \multirow[t]{2}{*}{ Total for Group } & 20.1 & Mixed-Silicon-Rich & 4.0 \\
\hline & & Total for Group & 15.7 \\
\hline \multicolumn{4}{|l|}{ Phosphorous-Rich } \\
\hline Apatite & 0.0 & & \\
\hline Mixed-Phosphorous-Rich & 0.0 & User-Defined-List & \\
\hline \multirow[t]{2}{*}{ Total for Group } & 0.0 & Ettringite & 0.0 \\
\hline & & Calcium Aluminate & 0.0 \\
\hline Carbon-Rich & & Total for Group & 0.0 \\
\hline Calcite & 31.7 & & \\
\hline Altered Calcite & 4.4 & & \\
\hline Dolomite & 0.0 & & \\
\hline Sulfated Dolomite & 0.0 & OTHER & 12.4 \\
\hline Ankerite & 2.0 & & \\
\hline Sulfated Ankerite & 0.0 & & \\
\hline Mixed-Carbon-Rich & 0.8 & & \\
\hline Total for Group & 39.0 & & \\
\hline \multicolumn{4}{|l|}{ Metal-Rich } \\
\hline Aluminum & 0.0 & & \\
\hline Titanium & 0.0 & & \\
\hline Iron & 0.0 & & \\
\hline Nickel & 0.0 & & \\
\hline Copper & 0.0 & & \\
\hline Chromium & 0.0 & & \\
\hline \multirow{3}{*}{ Total for Group } & 3.2 & & \\
\hline & 3.2 & & \\
\hline & & & 249 \\
\hline \multicolumn{4}{|c|}{ TOTAL NUMBER OF POINTS ANALYZED } \\
\hline \multicolumn{3}{|c|}{ Carbon Threshhold for Analysis } & 250 \\
\hline \multicolumn{3}{|l|}{ Oxygen Threshhold for Analysis } & 100 \\
\hline
\end{tabular}


UND-EERC SEMPC Mineral Classification Ver. 3.1, Run Date: Dec 171992 4985

BULK CHEMICAL COMPOSITION

\begin{tabular}{lrrrrrrrr}
\hline & \multicolumn{1}{c}{$\mathrm{A}$} & \multicolumn{1}{c}{$\mathrm{B}$} & \multicolumn{1}{c}{$\mathrm{C}$} & \multicolumn{1}{c}{$\mathrm{D}$} & \multicolumn{1}{c}{$\mathrm{E}$} & \multicolumn{1}{c}{$\mathrm{F}$} & \multicolumn{1}{c}{$\mathrm{G}$} & \multicolumn{1}{c}{$\mathrm{H}$} \\
\hline $\mathrm{SiO}_{2}$ & 4.9 & 4.3 & 8.8 & 50.1 & 0.7 & 23.1 & 10.2 & 10.9 \\
$\mathrm{Al}_{2} \mathrm{O}_{3}$ & 17.9 & 20.5 & 3.9 & 0.0 & 1.5 & 5.9 & 6.7 & 7.1 \\
$\mathrm{Fe}_{2} \mathrm{O}_{3}$ & 16.6 & 3.9 & 1.1 & 0.9 & 1.1 & 8.8 & 5.5 & 5.8 \\
$\mathrm{TiO}_{2}$ & 0.2 & 0.2 & 0.2 & 0.0 & 0.1 & 0.0 & 0.1 & 0.1 \\
$\mathrm{P}_{2} \mathrm{O}_{5}$ & 0.2 & 0.1 & 0.2 & 0.0 & 0.2 & 0.6 & 0.2 & 0.3 \\
$\mathrm{CaO}$ & 49.7 & 64.3 & 42.4 & 0.9 & 91.5 & 51.4 & 60.7 & 67.2 \\
$\mathrm{MgO}$ & 4.9 & 1.6 & 5.5 & 46.9 & 1.2 & 1.9 & 4.6 & 5.0 \\
$\mathrm{Na}_{2} \mathrm{O}$ & 2.0 & 1.3 & 5.8 & 0.2 & 0.6 & 2.2 & 2.4 & 3.4 \\
$\mathrm{~K}_{2} \mathrm{O}$ & 0.1 & 0.1 & 0.2 & 0.0 & 0.1 & 0.1 & 0.1 & 0.2 \\
$\mathrm{SO}_{3}$ & 3.3 & 3.1 & 31.1 & 0.5 & 2.9 & 5.6 & 9.0 & 0.0 \\
$\mathrm{Cl}_{2} \mathrm{O}_{7}$ & 0.1 & 0.4 & 0.2 & 0.3 & 0.1 & 0.3 & 0.3 & 0.0 \\
$\mathrm{Cr}_{2} \mathrm{O}_{3}$ & 0.0 & 0.2 & 0.0 & 0.1 & 0.1 & 0.0 & 0.1 & 0.0 \\
$\mathrm{BaO}$ & 0.1 & 0.1 & 0.5 & 0.1 & 0.1 & 0.1 & 0.1 & 0.0 \\
\hline
\end{tabular}

A. Cumulative bulk composition of OTHER.

B. Cumulative bulk composition of mixed-oxide-rich.

C. Cumulative bulk composition of mixed-sulfur-rich.

D. Cumulative bulk composition of mixed-carbon-rich.

E. Cumulative bulk composition of mixed-metal-rich.

F. Cumulative bulk composition of mixed-silicon-rich.

G. Cumulative bulk composition of the entire sample.

H. $\mathrm{SO}_{3-}, \mathrm{Cl}_{2} \mathrm{O}_{7}^{-}, \mathrm{Cr}_{2} \mathrm{O}_{3^{-}}, \mathrm{BaO}$-free composition of the entire sample. 
X-RAY POWDER DIFFRACTION REPORT

P.I.: Hurley DATE: 9/18/92 ICC \#: 48174946.XRD

SAMPLE DESCRIPTION: M261 PFBR Bed Material $800^{\circ} \mathrm{C}$

\begin{tabular}{cc}
\hline Major Phase(s): & Nominal Composition(s): \\
Calcite & $\mathrm{CaCO}_{3}$ \\
$\frac{\text { Minor Phase(s): }}{\text { Quartz }}$ & Nominal Composition(s): \\
Anhydrite & $\mathrm{SiO}_{2}$ \\
Lime & $\mathrm{CaSO}_{4}$ \\
Hematite & $\mathrm{CaO}$ \\
\hline
\end{tabular}




\section{X-RAY POWDER DIFFRACTION REPORT}

P.I.: Hurley DATE: 9/18/92 ICC\#: 48174947.XRD

SAMPLE DESCRIPTION: M262 PFBR Bed Material $850^{\circ} \mathrm{C}$

\begin{tabular}{cc}
\hline Maior Phase(s): & Nominal Composition(s): \\
Calcite & $\mathrm{CaCO}_{3}$ \\
Minor Phase(s): & Nominal Composition(s): \\
Quartz & $\mathrm{SiO}_{2}$ \\
Anhydrite & $\mathrm{CaSO}_{4}$ \\
Lime & $\mathrm{CaO}$ \\
Hematite & $\mathrm{Fe}_{2} \mathrm{O}_{3}$ \\
\hline
\end{tabular}


P.I.: Hurley DATE: 9/18/92 ICC\#: 48174948.XRD

SAMPLE DESCRIPTION: M262 PFBR Wall Deposits $850^{\circ} \mathrm{C}$

\begin{tabular}{cc}
\hline Major Phase(s): & Nominal Composition(s): \\
\hline Oldhamite & $\mathrm{CaS}$ \\
Lime & $\mathrm{CaO}$ \\
Mayenite & $\mathrm{Ca}_{12} \mathrm{Al}_{14} \mathrm{O}_{33}$ \\
Minor Phase(s): & Nominal Composition(s): \\
Calcite & $\mathrm{CaCO}_{3}$ \\
Periclase & $\mathrm{MgO}$ \\
Merwinite & $\left.\mathrm{Ca} \mathrm{Mg}_{(\mathrm{SiO}}\right)_{2}$ \\
Portlandite & $\mathrm{Ca}(\mathrm{OH})_{2}$ \\
Possible Clinopyroxene & $\mathrm{Ca}\left(\mathrm{Fe}, \mathrm{Mg}_{2} \mathrm{Al}\right)_{\mathrm{Si}} \mathrm{O}_{6}$ \\
Quartz & $\mathrm{SiO}$ \\
\hline
\end{tabular}


X-RAY POWDER DIFFRACTION REPORT

P.I.: Hurley DATE: 9/18/92 ICCH: 48174949.XRD

SAMPLE DESCRIPTION: PFBR Raw Bed Material for B\&W CCT5 Tests

Major Phase(s):

Calcite

Minor Phase(s):

Quartz
Nominal Composition(s):

$\mathrm{CaCO}_{3}$

Nominal Composition(s):

$\mathrm{SiO}_{2}$ 


\section{X-RAY POWDER DIFFRACTION REPORT}

P.I.: Hurley DATE: 9/18/92 ICC\#: 48174950.XRD

SAMPLE DESCRIPTION: M263 PFBR Bed Material Center Blend $800^{\circ} \mathrm{C}$

\begin{tabular}{cc}
\hline Major Phase(s): & Nominal Composition(s): \\
Calcite & $\mathrm{CaCO}_{3}$ \\
Minor Phase(s): & Nominal Composition(s): \\
Hematite & $\mathrm{Fe}_{2} \mathrm{O}_{3}$ \\
Lime & $\mathrm{CaO}$ \\
Portlandite & $\mathrm{Ca}(\mathrm{OH})_{2}$ \\
Quartz & $\mathrm{SiO}_{2}$ \\
Anhydrite & $\mathrm{CaSO}_{4}$ \\
\hline
\end{tabular}




\section{X-RAY POWDER DIFFRACTION REPORT}

P.I.: Hurley DATE: 9/21/92 ICC\#: 48174951.XRD

SAMPLE DESCRIPTION: M263 PFBR Wall Deposit Center Blend $800^{\circ} \mathrm{C}$

Major Phase(s):

Oldhamite

Merwinite

Mayenite

Ferrite Spinel

Periclase

Minor Phase(s):

Calcite

Lime

Portlandite

Clinopyroxene

Quartz
Nominal Composition(s):

Cas

$$
\begin{gathered}
\mathrm{Ca}_{3} \mathrm{Mg}\left(\mathrm{SiO}_{4}\right)_{2} \\
\mathrm{Ca}_{12} \mathrm{Al}_{14} \mathrm{O}_{33}
\end{gathered}
$$$$
(\mathrm{Mg}, \mathrm{Fe})\left(\mathrm{Fe}, \mathrm{Al}_{2} \mathrm{O}_{4}\right.
$$

$\mathrm{MgO}$

Nominal Composition(s):

$\mathrm{CaCO}_{3}$

$\mathrm{CaO}$

$\mathrm{Ca}(\mathrm{OH})_{2}$

$\mathrm{Ca}(\mathrm{Fe}, \mathrm{Mg}, \mathrm{Al}) \mathrm{Si}_{2} \mathrm{O}_{6}$

$\mathrm{SiO}_{2}$ 


\section{X-RAY POWDER DIFFRACTION REPORT}

P.I.: Hurley DATE: 9/22/92 ICCh: 48174952.XRD

SAMPLE DESCRIPTION: PFBR M265 Blended Center $850^{\circ} \mathrm{C}$

\begin{tabular}{cc}
\hline Maior Phase(s): & Nominal Composition(s): \\
Calcite & $\mathrm{CaCO}_{3}$ \\
Lime & $\mathrm{CaO}$ \\
Hematite & $\mathrm{Fe}_{2} \mathrm{O}_{3}$ \\
Minor Phase(s): & Nominal Composition(s): \\
Oldhamite & $\mathrm{CaS}$ \\
Quartz & $\mathrm{SiO}_{2}$ \\
Anhydrite & $\mathrm{CaSO}_{4}$ \\
\hline
\end{tabular}




\section{X-RAY POWDER DIFFRACTION REPORT}

P.I.: Hurley DATE: 9/28/92 ICC\#: 48174954.XRD

SAMPLE DESCRIPTION: PFBR M265 Bed Material Center Blend $850^{\circ} \mathrm{C}$ - No Limestone

Major Phase(s):

Hematite

Minor Phase(s):

Quartz

Portlandite

Oldhamite

Periclase

Pyrrhotite

Pyrite
Nominal Composition(s):

$\mathrm{Fe}_{2} \mathrm{O}_{3}$

Nominal Composition(s):

$\mathrm{SiO}_{2}$

$\mathrm{Ca}(\mathrm{OH})_{2}$

Cas

$\mathrm{MgO}$

$\mathrm{Fe}_{1-\mathrm{z}} \mathrm{S}$

$\mathrm{FeS}_{2}$ 


\section{X-RAY POWDER DIFFRACTION REPORT}

P.I.: Hurley DATE: 10/16/92 ICC\#: 48174981.XRD

SAMPLE DESCRIPTION: Emathlite for B\&W PFBR Tests

Major Phase(s):

Quartz

Cristobalite

Minor Phase(s):

Clinopyroxene

Tricalcium Aluminate

Possible Calcite
Nominal Composition(s):

$\mathrm{SiO}_{2}$

$\mathrm{SiO}_{2}$

Nominal Composition(s):

$\mathrm{Ca}(\mathrm{Fe}, \mathrm{Mg}, \mathrm{Al}) \mathrm{Si}_{2} \mathrm{O}_{6}$

$\mathrm{Ca}_{3} \mathrm{Al}_{2} \mathrm{O}_{3}$

$\mathrm{CaCO}_{3}$ 
X-RAY POWDER DIFFRACTION REPORT

P.I.: Hurley DATE: 10/16/92 ICC\#: 48174982.XRD

SAMPLE DESCRIPTION: Center Blend $850^{\circ} \mathrm{C}$ Kerford Limestone

\begin{tabular}{cc}
\hline Major Phase(s): & Nominal Composition(s): \\
Lime & $\mathrm{CaO}$ \\
Bredigite & $\mathrm{Ca}_{1.75} \mathrm{Mg}_{0.25} \mathrm{SiO}_{4}$ \\
Brownmillerite & $\mathrm{Ca}_{2}(\mathrm{Al}, \mathrm{Fe})_{2} \mathrm{O}_{5}$ \\
Minor Phase(s): & Nominal Composition(s): \\
Anhydrite & $\mathrm{CaSO}_{4}$ \\
Periclase & $\mathrm{MgO}$ \\
Oldhamite & $\mathrm{CaS}$ \\
\hline
\end{tabular}




\section{X-RAY POWDER DIFFRACTION REPORT}

P.I.: Hurley DATE: 10/16/92 ICC\#: 48174983.XRD

SAMPLE DESCRIPTION: Center Blend $850^{\circ} \mathrm{C}$ Dolomite

\begin{tabular}{cc}
\hline Major Phase(s): & Nominal Composition(s): \\
Hematite & $\mathrm{Fe}_{2} \mathrm{O}_{3}$ \\
Minor Phase(s): & Nominal Composition(s): \\
\hline Anhydrite & $\mathrm{CaSO}_{4}$ \\
Quartz & $\mathrm{SiO}_{2}$ \\
Oldhamite & $\mathrm{CaS}$ \\
Dolomite & $\mathrm{CaMg}\left(\mathrm{CO}_{3}\right)_{2}$ \\
Calcite & $\mathrm{CaCO}_{3}$ \\
\hline
\end{tabular}




\section{X-RAY POWDER DIFFRACTION REPORT}

P.I.: Hurley DATE: 10/16/92 ICC\#: 48174984.XRD

SAMPLE DESCRIPTION: Center Blend $850^{\circ} \mathrm{C}$ Emathlite + Kerford Limestone

Major Phase(s):

Hematite

Calcite

Minor Phase(s):

Anhydrite

Quartz

Oldhamite

Lime

Greigite
Nominal Composition(s):

$\mathrm{Fe}_{2} \mathrm{O}_{3}$

$\mathrm{CaCO}_{3}$

Nominal Composition(s):

$\mathrm{CaSO}_{4}$ $\mathrm{SiO}_{2}$

CaS

$\mathrm{CaO}$

$\mathrm{Fe}_{3} \mathrm{~S}_{4}$ 
P.I.: Hurley DATE: 10/16/92 ICC\#: 48174985.XRD

SAMPLE DESCRIPTION: Center Blend $850^{\circ} \mathrm{C}$ Kerford Limestone + CaS

Major Phase(s):

Lime

Minor Phase(s):

Anhydrite

Periclase

Brownmillerite

Tricalcium Aluminate
Nominal Composition(s):

$\mathrm{CaO}$

Nominal Composition(s):

$\mathrm{CaSO}_{4}$

$\mathrm{MgO}$

$\mathrm{Ca}_{2}(\mathrm{Al}, \mathrm{Fe})_{2} \mathrm{O}_{5}$

$\mathrm{Ca}_{3} \mathrm{Al}_{2} \mathrm{O}_{6}$ 




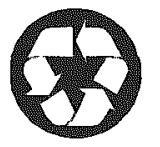

This cover stock is $30 \%$ post-consumer waste and $30 \%$ pre-consumer waste, and is recyclable. 
